\title{
Compressed Air MASiER Energy Storage
}

PRELIMINARY DESIGN AND SITE DEVELOPMENT

PROGRAM IN AN AQUIFER

DOE CONTRACT NO. ET-78-C-01-2159

\section{Final Draft}

Task 2- Volume 3 of 3

CHARACTERIZE AND EXPLORE POTENTIAL SITES AND

PREPARE RESEARCH AND DEVELOPMENT PLAN

DECEMBER 1980

\section{Public Service Indiana}

1000 EAST MAIN STREET. PLAINFIELD. INDIANA 46168

T.W. MCCAFFERTY

PROJECT MANAGER

PREPARED FOR

DEPARTMENT OF ENERGY

9800 SOUTH CASS AVENUE

ARGONNE, ILLINOIS 60439

C.PDEMOS

PROGRAM MANAGER
ELECTRIC POWER RESEARCH INSTITUTE 3412 HILLVIEW AVENUE

PALO ALTO. CALIFORNIA 93404

RB SCHAINKER

PROJECT MANAGER 


\section{DISCLAIMER}

This report was prepared as an account of work sponsored by an agency of the United States Government. Neither the United States Government nor any agency Thereof, nor any of their employees, makes any warranty, express or implied, or assumes any legal liability or responsibility for the accuracy, completeness, or usefulness of any information, apparatus, product, or process disclosed, or represents that its use would not infringe privately owned rights. Reference herein to any specific commercial product, process, or service by trade name, trademark, manufacturer, or otherwise does not necessarily constitute or imply its endorsement, recommendation, or favoring by the United States Government or any agency thereof. The views and opinions of authors expressed herein do not necessarily state or reflect those of the United States Government or any agency thereof. 


\section{DISCLAIMER}

Portions of this document may be illegible in electronic image products. Images are produced from the best available original document. 
Compressed Air Energy Storage

Preliminary Design and Site Development Program in an Aquifer DOE Contract No. ET-78-C-01-2159

Final Draft

Task 2 - Milestone Report

Volume 3 of 3 .

Characterize and Explore Potential Sites and

Prepare Research and Development Plan

(Site Investigation Study)

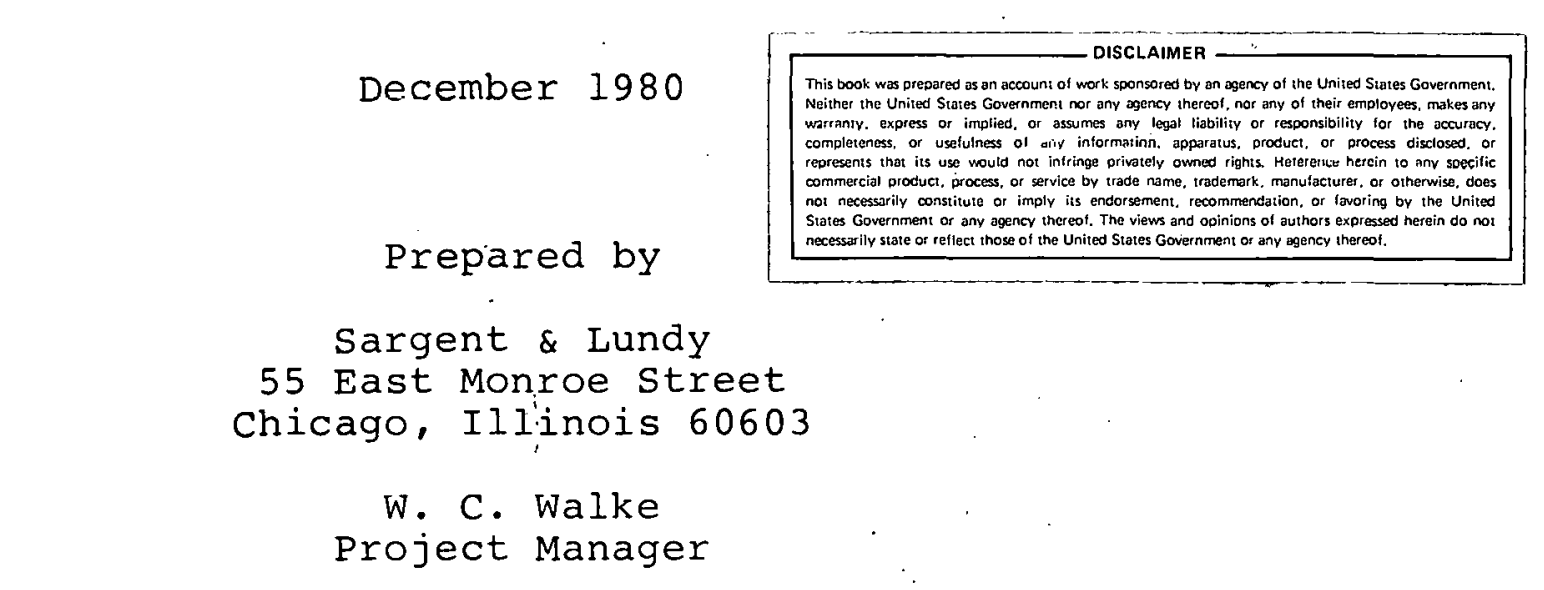

As Subcontractor to

Public Service Company of Indiana, Inc. 1000 East Main Street Plainfield; Indiana 46168

T. W. McCafferty

Project Manager

Prepared for

Department of Energy 9800 South Cass Avenue Argonne, Illinois 60439 C. P. Demos

Program Manager
Electric Power Research Institute 3412 Hillview Àvenue

Palo. Altu, Californi.a 93404

R. B. Schainker

Project Manager 


\section{THIS PAGE}

\section{WAS INTENTIONALLY LEFT BLANK}


A.5 
CAES-T2

\section{Chapter 5}

EVALUATION OF FINAL SITES

Following the evaluation of the potential sites, seven sites were selected for further study. This study was conducted to determine the suitability of the sites to undergo a field drilling and testing program consisting of four phases: drilling structure test wells, drilling injection-witharawal and observation wells, performing an dyuifer pumping test, and performing an air injection test.

\subsection{DESCRIPTION OF FIELD DRILLING AND TESTING PROGRAM} The purpose of the field drilling testing program is to test the concept of underground compressed air energy storage (CAES) and to provide design input prior to the construction of a CAES demonstration plant. To ensure that the site chosen for the test program is practicable, it is necessary to perform a four-stage test program. The purpose of each portion of the test program is to gain more geologic and reservoir information to ensure a high confidence level for the future phase of the CAES development program: the construction of a working CAES demonstration plant. Each phase adds more and different geologic and reservoir information, adds a greater confidence level against any unwarranted damage claims, and provides data for plant iicensing.

The four phases of the field drilling and testing program for which the suitability of the sites was evaluated are described individually in the following subsections. 


\section{1 .1 Structure Test Wells}

Whe structure test wells are arilled to delineate the geolnginal structure on the top of the proposed iteservoir unit. These wells are approximately 4.5 inches in diameter and are drilled to a known stratigraphic marker. The structure found nn this stratigraphic markcr alluws the geologists to interpret the structure on the deepcr reservoir unit. During the driling it is nesessary to dig a shallow pit near the drilling rig to circulate the drilling mud and to collect rock cuttings for stratigraphic interpretation. Wlien edch well is completed, the mud will be removed from the circulation pit and moved to the next well to be drilled, the rock cuttings will be removed from the site and disposed of in an acceptable manner, and the circulation pit will be backfilled and leveled to its original condition. The number of structure test wells at any given site depends on the geologic control already present at the site.

The structure test wells are loc̣ged by a ceologist using drill cuttings and geophysically logged using an electricinduction well logging tool. The electric-induction well logging tool gives another method for the geologist to check geologic correlation and lithologic interpretation. This geophysical logging also allows for the determination of bed thicknesses and of porous and nonporous rock units in a sedimentary sequence, which is very important for the determination of primary and secondary caprocks and of any potential aquifers above the reservoir unit. 
CAES-T2

The structure test wells provide data to prepare structure contour maps showing the configuration of the reservoir unit. These data are used to properly place the injectionwithdrawal wells on the crest of the structure. The well logging portion of this phase of the work provides data on porous zones above the caprock. Delineating the porous zones provides data for proper completion of the caprock observation wells. This well is important to detect any intercommunication through the caprock that could provide a path for air leakage during air injection and storage.

\subsubsection{Injection-Withdrawal and Observation Wells}

A specific size production casing for injection-withdrawal wells depends upon the individual field and its characteristics. The pressure and permeability of the storage reservoir and the thickness of the air bubble after the reservoir is completely full determine the maximum rate of flow from each individual well and the casing size needed to prevent excessive friction loss. However, in order to evaluate each site for the testing program, a 7-inch outside diameter (O.D.) casing was used for all sites. This casing would extend from the ground surface into the air storage reservoir. Generally, one well is initially used as a pumped well for the aquifer pumping test, and the others are used for observation wells during this pumping test. During the air testing phase all injection-withdrawal wells are used for air injection.

The observation wells are completed as 4.5-inch o.D., cased wells. Their purpose is to observe the changes in water levels within the reservoir unit and any changes in water levels above the caprock during the pumping test. It is important to detect any communication through the caprock that could provide a path for air leakage during air injection and 
The drilling rig and the support equipment necessary to drill these wells are larger than the drilling rig necessary to drill the structure test wells. This drilling rig, with the various storage and temporary facilities, will probably occupy approximately 1 acre and operate 24 hours nạily from the start of a well until well completion. Upon completion of eacli well, the drill rig, all temporary structures, and all trash and debris will be removed from the well location.

During the air injection phase of the test and later if the site is utilized for a demonstration plant, these observation wells will be used to observe bubble development and to check for potential leakage from the reservoir. If the site is not used, then both sets of wells will be abandoned and plugged using a method that meets state guidelines.

The drilling and geophysical logging of the injection-withdrawal wells and observation wells provide data on the thickness and nature of the reservoir and caprock units. The reservoir core obtained during the drilling of these wells will be tested for porosity, pormcability, and residual wälér cuntent. These data are used for preliminary wellfield design and modelina bubble growth and provide for an accurate calculation of ultimate reservoir capacity.

The primary purpose of the injection-withdrawal wells is to pump water from the reservoir during the aquifer pumping test and to inject air into the reservoir during the air injection test. The observation wells will be used to observe water level changes during the aquifer pumping test and to determine the 
extent of intercommunication throughout the reservoir during the air injection test.

\section{1 .3 Aqquifer Pumping Test}

The aquifer pumping test is performen to ensure that the caprock has adequate integrity for the project and to provide in situ permeability results. This test is performed by installing an electrically-driven pump in one of the injection-witharawal wells and pumping continuously at a rate of approximately $100 \mathrm{gpm}$ for 40 to 60 days. The other wells are used as observation wells for performing water level measurements during the pumping test. The water produced during the test is carried by a line, laid directly on the ground surface, to a water holding pond.

The water holding pond will cover approximately 5 acres and be approximately 10 feet deep. This pond will be constructed of local materials. The topsoil will be stripped and stored adjacent to the holding pond. The water produced during the test will probably be a brine with up to 40,000 ppm of total dissolved solids. The pond will be constructed such that the seepage rate from the pond meets all applicable state and federal guidelines for this type of wastewater. When the pumping test is completed, the water from the holding pond will be reinjected into the reservoir unit, the holding pond back-filled, and the area returned to its original condition.

The aquifer pumping test provides data on the ability of 
the caprock to contain air within the reservoir, ensure that there is no large-scale communication between the reservoir and stratigraphically higher porous zones or the ground surface, and provide for a measurement of in situ permeabilities. It is very important to determine the presence of any large-scale leakage and the nature of any intercommunication, as the workability of the CAES projest depende on the ability of the storage reservoir to contain air.

A determination of the in situ permeduility 15 important to prepare a detailed design and cost estimate of the wellfield for the CAES demonstration plant. An example of its imporm tance is in the modeling of the Media site where both laboratory and in situ permeability data are available. The calculated number of production wells necessary for a 1000 MW plant using laboratory data is 235, whereas using the in situ data in the modeling program results in a value of 28 . Using a cost of approximately $\$ 60$ per foot for the production wells results in a cost differential between the two possible wellfields of approximately $\$ 25,000,000$.

\section{1 .4 Air Injection Test}

The purpose of the air injection test is to determine the ability of the reservoir unit to accept air during injection and its ability to deliver it during withdrawal. To perform this test, portable air compressors are installed, and air injected into the injectinn-witharawal wells until a small air bubble is developed. Various flow tests 
are then performed to measure the delivery rate. When the air injection test is completed, the compressors will be removed from the site.

The results of the air injection test program determine whether the concept of compressed air storage in aguifers and the cyclic nature of this type of storage is feasible for a demonstration CAES plant.

\subsection{CRITERIA AND METHODS}

Three categories of criteria were used to evaluate the desirability of the sites for the testing program. The three categories - geologic, economic, and environmental - are the same as those that were used for evaluating the potential sites, but the criteria used in each category were modified for the final site evaluations. The geologic considerations remained basically the same, since the factors that determine. a site's suitability for air reservoir development are much the same as those that determine which sites have higher probabilities for successful, informative test results. The economic considerations were limited to those costs associated with the testing program exclusively. The environmental considerations were limited to cultural resources and ecology, which could be affected by testing activity, and did not include air quality concerns since no emissions are associated with testing activity.

A numerical rating system (1 through 5) was used to compare the sites in the three categories, but no weighting factors were used and no total site scores were determined. 


\section{2 .1 Geologic Considerations}

Several of the geologic considerations developed for the regional portion of the site study described in subsection 4.1 .1 were used when evaluating the suitability of each of the seven sites for a test proqram. The considerations reexamined in this portion of the study were caprock, permeability, porosity, total closure, and type of reseivuir.

Also examined during this portion of the site study was the approximate time period necessary to develop a 1 x 109 cubic foot test air bubte. The time for the development of the test air bubble was found by prorating the development times required for full plant development. The formula used to calculate these approximate times was:

$$
T^{\prime}=\frac{(0.7 \mathrm{psi} / \mathrm{ft}) \mathrm{d}-\mathrm{P}_{\mathrm{d}}}{100 \mathrm{psi}} \times \frac{1}{\bar{V}_{S}} \times^{T}
$$

where: $d=$ discovery depth in feet;

$\mathrm{P}_{\mathrm{d}}=$ discovery pressure in storage reservoir in psi;

$\mathrm{V}_{\mathrm{S}}=$ stored air volume in billions of cubic feet; and

$\mathrm{T}=$ time required to develop a full bubble at a pressure equal to $0.7 \mathrm{psi} /$ ft of deplh.

The rating criteria developed for bubble development time are as follows:

\begin{tabular}{rrc}
$\begin{array}{r}\text { Development Time } \\
\text { (months) }\end{array}$ & Rating \\
\cline { 2 - 2 } more than & 12 & 1 \\
9 & -12 & 2 \\
6 & -9 & 3 \\
3 & -6 & 4 \\
less than 3 & 5 \\
$5-8$ &
\end{tabular}


The number and location of wells necessary for the field drilling and testing program were also determined. The number of structure test welis necessary depends on the amount of structural control available to prepare the original structure contour maps. The number of injection-withdrawal wells and observation wells necessary depends primarily on the areal extent of the site. The locations of these wells were determined and illustrated on topographic maps.

\subsubsection{Economic Considerations}

The economic considerations include all those costs associated with the four phases of the testing program. The cost items specific to each site that were included are drilling and logging of structure test wells, drilling and logging of injection-withdrawal and observation wells, pumping test, laboratory testing, air injection testing, and the services of the reservoir consultants. The cost rating system developed for the testing program is based on the total cost estimate. The rating criteria used in this evaluation are as follows:

$\begin{array}{rc}\begin{array}{r}\text { Cost } \\ \text { (millions of dollars) }\end{array} & \text { Rating } \\ \text { more than } 3.5 & 1 \\ 3.0-3.5 & 2 \\ 2.5-3.0 & 3 \\ 2.0-2.5 & 4 \\ \text { less than } 2.0 & 5\end{array}$




\subsubsection{Environmental Considerations}

The environmental characteristics evaluated for the testing program consisted of cultural resources considerations and ecological considerations. The evaluation of the sites for cultural. resnurses required an evaluation of the effects of each well. The location of each test well was first noted un tupographic maps of each site. Each site was then visited to evaluate the type of land use on or near each well site. The regional and site-specific ecology of all sites were investigated for the site तipyelopment phase of the site study using the methods described in subsection 4.1.3.3. Additional information collected for the test program phase of the site study consisted of numbers and locations of the required test wells and holding ponds, the necessity of creating new access routes for the placement of test wells, and the vegetative habitat in the immediate vicinity of these testing activities.

\subsubsection{Cultural Resources Considerations}

The evaluation of the sites for cultural resources required an evaluation of the type of land use on or near each well site. The uses evaluated were residential and commercial, institutional, recreational, historical and archaeological, and agricultural. In the evaluation of the sites, proximity to residential, recreational, and institutional uses was considered to result in a more significant impact than the amount of farmland preempted or the proximity to historical or archaeological uses. This difference in relative importance 
was accounted for by weighting the former categories twice as heavily as the latter in developing the composite cultural resources rating.

\subsection{Proximity of Each Well to Residential and Commercial Structures}

The total number of residential and commerical structures within 1000 feet of well sites was used to determine noise impact. The noise impact was assumed proportional to the number of these structures. This number was used to establish the following rating system:

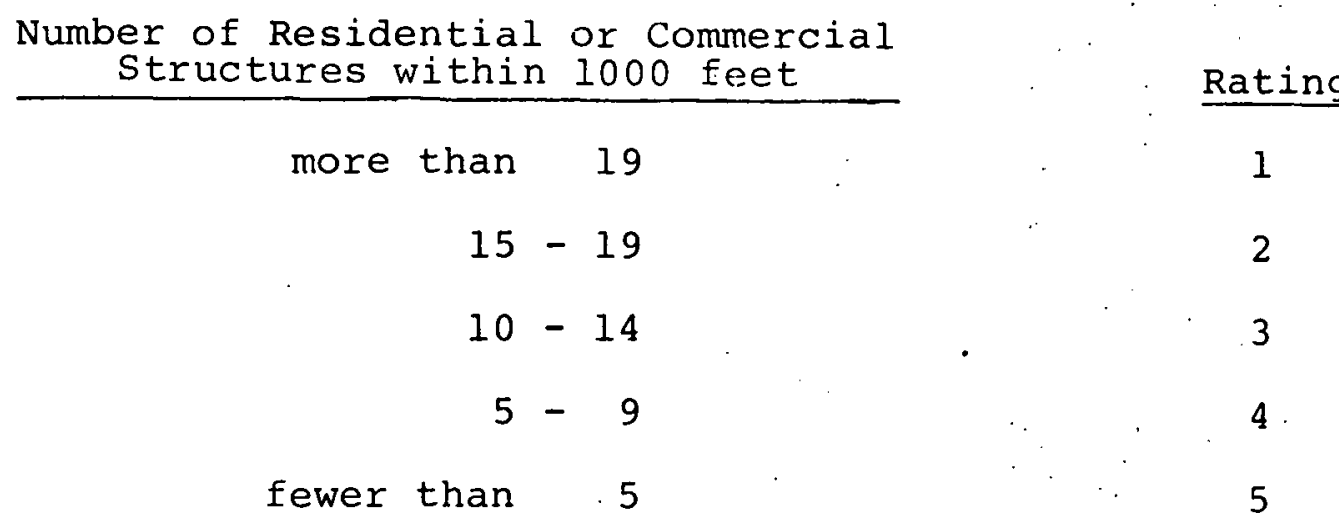

5.2.3.1.2 Proximity of Each Well to Instititutional Uses Incompatible institutional uses, such as colleges and schools, were noted to determine both aesthetic and noise impact. The distance of the nearest institutional structure was used to establish the following rating system: Distance from Institutional Property (feet)

Rating

On the Property

less than 1000

$1000-2000$

$2000-2640$ 


\subsection{Proximity of Recreational Uses}

Known and planned recreational uses were located to determine whether they would be disturbed by any of the test wells. The wells were considered to have an adverse noise and aesthetic impact if they were on or near a recreational area. The distance of the nearest recreational area was used to establish the following rating system:

$$
\text { Distance from }
$$

Recreational Property (feet)

On the Property

less than 1.000

$$
1000-2000
$$$$
2000-2640
$$

greater than 2640
Rating

5.2.3.1.4 Proximity to Historical or Archaeological Sites Known historical and archaeological sites were identified to determine the impact of the wells. The distance of the nearest historical or archaeological site was used to establish the following rating system:

Distance from Historical

or Archaeological Property (feet)

$\underline{\text { Rating }}$

On the site

less than 1000

2

$1000-2000$

$2000-2640$

4

greater than 2640 


\subsection{Amount of Agricultural Lands Preempted}

The sites were examined to determine how much land would be temporarily taken out of production and whether sperialized cropland areas would be disturbed. The following rating system was established for this criterion:

\begin{tabular}{lc} 
Description & Rating \\
\hline Strong possibility of disturbing & 1 \\
specialized cropland areas or & \\
more than 400 acres of farmland & 2 \\
Some disturbance of specialized \\
cropland areas or \\
300 to 400 acres of farmland \\
taken out of production \\
Minor disturbance of specialized \\
crops or \\
200 to 300 acres of farmland \\
removed from production \\
No specialized crops disturbed and \\
loo to 200 acres of farmland \\
removed from production \\
No specialized crops disturbed and \\
under 100 acres of farmland \\
disturbed
\end{tabular}

\subsubsection{Ecological Considerations}

The ecological suitability of the sites for testing was evaluated based on the proximity of the sites to ecologically unique areas, the likelihood of endangered species occurring in the test areas, and the amount of ecologically valuable habitat that would be disturbed by testing at each site. Because the overall ecological impact that would result from testing at 
any site is much less than the impact that would result from site development, the criteria used to assign numerical ratings for the test program were made more sensitive to small differences between sites in the probability of endangered speries orcurrence and the amount of valuable habitat that would be disturbed. The numerical ratings obtained for each of the three factors at each site were averaged to obtain an overall score for the ecological desirability of conducting the testing program at that site. l'he rating criteria are described by topic in the following subsections.

\subsection{Endangered Species}

The probability of a species listed as threatened or endangered by the U.S. Fish and Wildlife service (1) or the Illinois Department of Conservation (2) occurring in the test areas was evaluated. Based on the estimated prohahility the folloving criteria were established:

Description

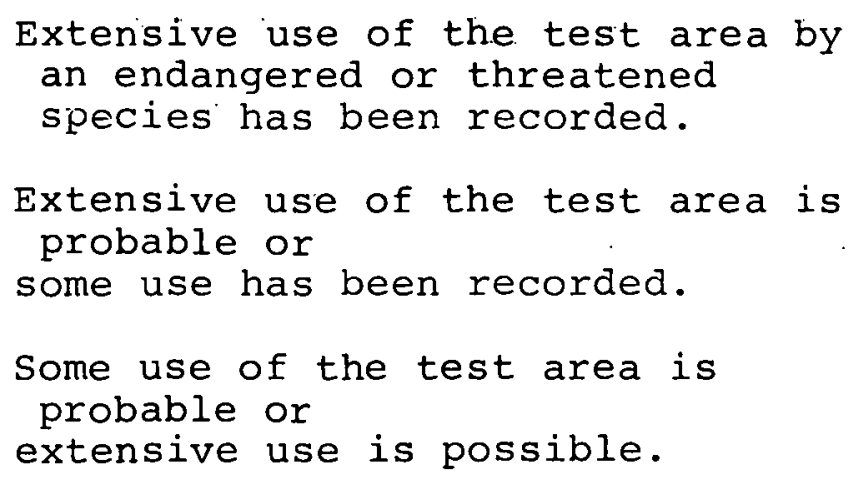

Rating 
Some use of the test area is possible but

extensive use is unlikely.

Any use of the test area by an

threatened species is unlikely.

\subsection{Ecologically Unique Areas}

Ecologically unique areas include virgin forest or prairie, unusual wetlands or canyons, and pristine waterways. Based on the proximity of well sites to any of these areas, the following criteria were established:

One or more testing activities

within an ecologically unique area.

More than one ecologically unique

area within 1000 feet of a

test area.

One ecologically unique area within

1000 feet of a test area.

One or more ecologically unique areas within 5 miles but not within 1000 feet of the test area.

No ecologically unique area within

5 miles of the test area.

\subsection{Habitat Disturbance}

The amount and type of ecologically valuable but not unique habitat that would be disturbed at each site were evaluated. Based on the type of habitat and the extent of testing activities, the following criteria were established: 


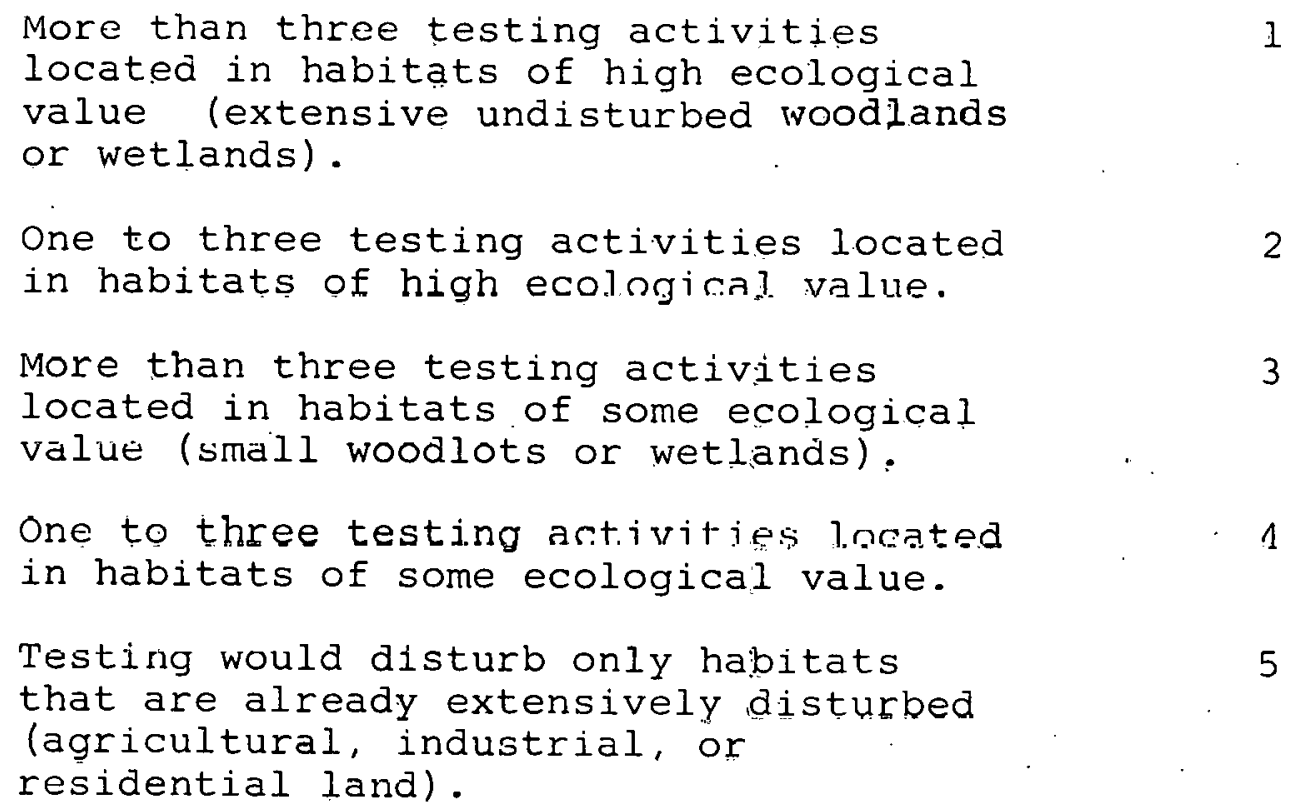

\subsection{CHARACTERISTICS OF FINAL SITES}

\subsubsection{Wapella East}

\subsubsection{Geologic Considerations}

A discussion of the geologic conditions present at the Wapella East site is presented in Subsection 4.2.1.2.

The data from 69 wells were used as control to prepare the structure contour map. To properly delineate the structure, three additional structure test wells drilled to a depth of approximately 1750 feet are required. The testing program also requires two injection-withdrawal wells 2400 feet deep, three reservoir observation wells 2500 feet deep, and one caprock observation well 2100 feet deep. Figure 5-1 locates these proposed well sites. 


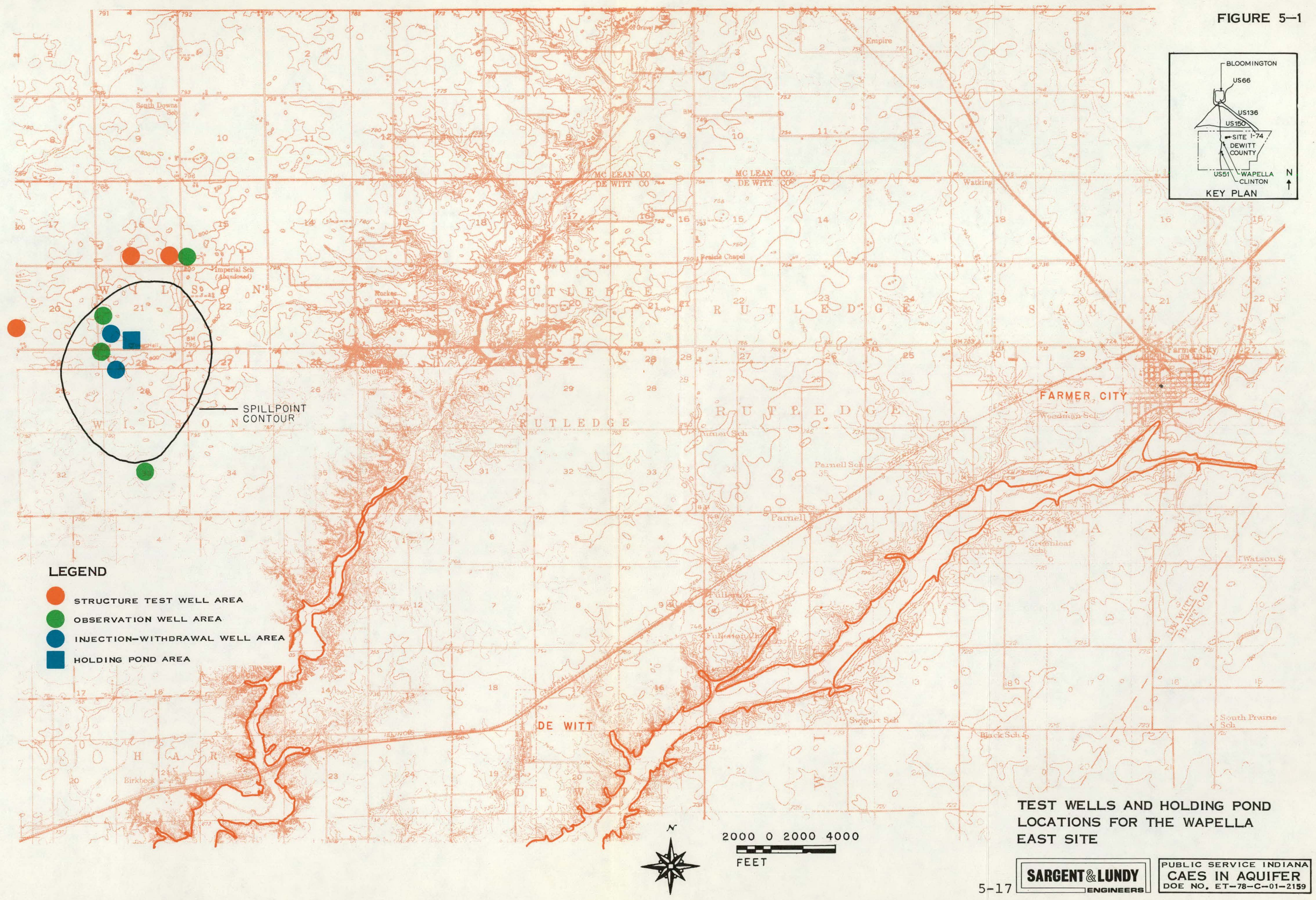




\section{THIS PAGE}

\section{WAS INTENTIONALLY LEFT BLANK}


The time required to develop a test air bubble of approximately $1 \times 10^{9}$ cubic feet, using an injection pressure of 100 psi over discovery pressure, is approximately 3.5 months.

\subsubsection{Cultural Resources}

Only nine wells and one holding pond are required for the testing program at the Wapella East site, and all of their locations are on cultivated cropland. Approximately 12.5 acres are required for the testing program, and this loss of productive land should have no significant impact on agricultural production in the area. There are only two residential structures within 1000 feet of well sites.

These wells are two structure test wells, and since these are estimated to have drilling operations for only about 1.5 week each, the impact on these residences should be very little.

This site presents no major land use or cultural activity that would be affected by the testing program. The nearest recreational site to any well site is the Lake Clinton state Recreational Area approximately 2 miles southeast. The testing program should not have any significant noise or aesthetic impact on this recreational area. No historical, archeological, commercial, or institutional activities should be affected by the testing program. There is an active oil field on the site, but the testina proaram should not interfere with its operation. 


\subsubsection{Ecology}

A detailed description of the ecology of the Wapella East site and the region in which it is located may be found in Subsection 4.2 .1 .7 .

Testing at this site will involve the disturbance of intensively farmed cropland. Since this type of habitat is already extensively disturbed and is very common in the region, the testing program is not expected to have any significant ccological cffects. Any use of the test arca by an endangered species appears highly unlikely. No ecologically unique area is known to exist within 5 miles of the test area.

\section{3 .2 DeLand}

\subsubsection{Geologic Considerations}

A discussion of the geologic conditions present at the Deland site is presented in Subsection 4.2.2.2.

The data from 12 wells were used as control to prepare the structure contour maps. To refine these maps and properly delineate the structure, 12 additional structure test wells drilled to a depth of approximately 1950 feet are required. The testing program also requires two injeclionwithdrawal wells 2550 feet deep, two reservoir observation wells 2650 feet deep, and one caprock observation well 2250 feet deep. Figure 5-2 locates these proposed well sites. 


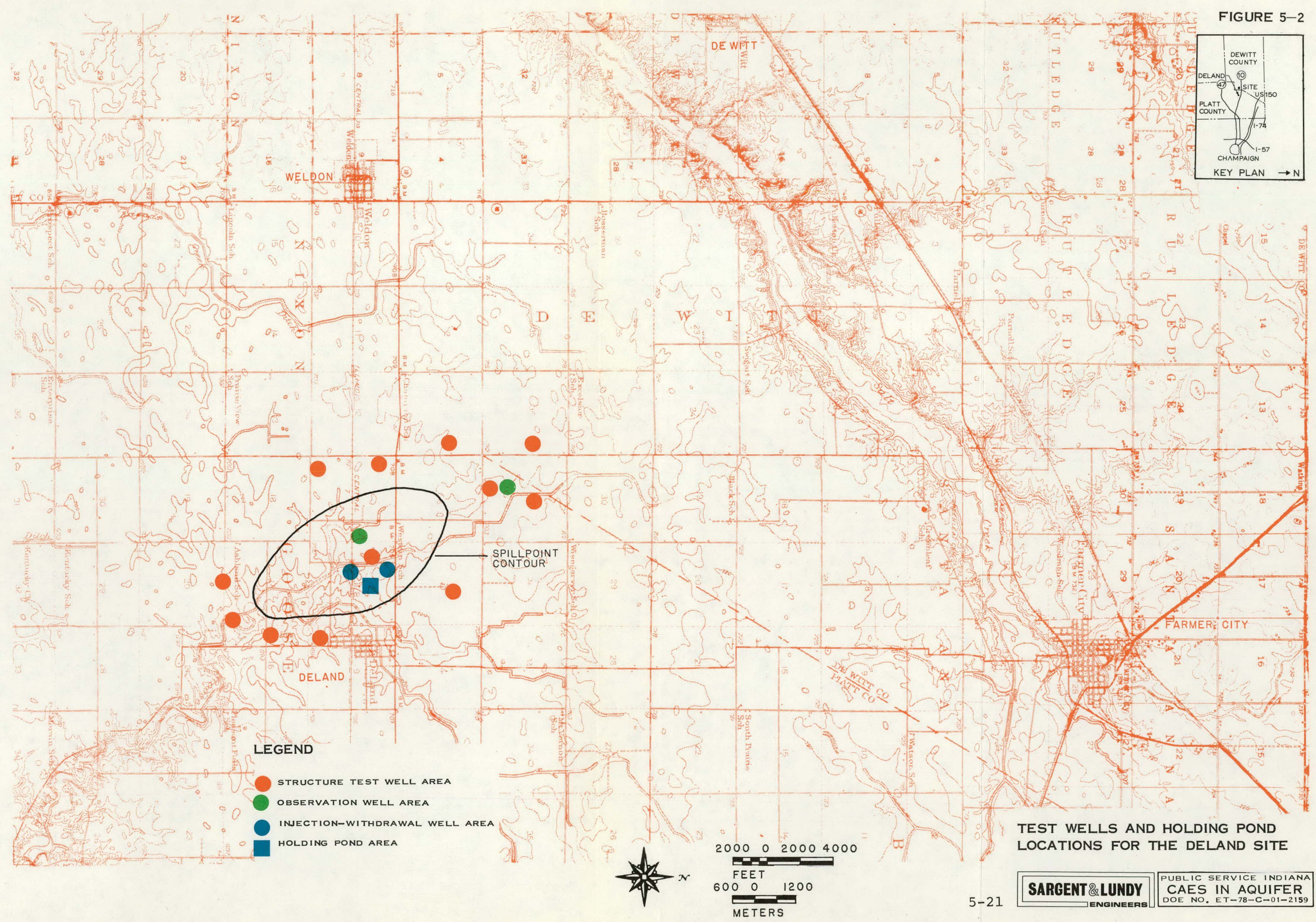




\section{THIS PAGE}

\section{WAS INTENTIONALLY \\ LEFT BLANK}


The time required to develop a test air bubble of approximately $1 \times 10^{9}$ cubic feet, using an injection pressure of 100 psi over discovery pressure, is approximately 2.8 months.

\subsubsection{Cultural Resources}

Seventeen wells and one holding pond are required for the testing program at the DeLand site. All but two of these wells are on cultivated cropland, and only about 14.5 acres will be disturbed, most for only a relatively short time. It is therefore not expected that the testing program will have any effect on agricultural production in the area. The effect on residential structures should also be very little. Only seven houses are within 1000 feet of any test well, and six of these are located close to structure test wells and should be affected by drilling noise for only about 1.5 weeks for each well. The one residential structure located within 1000 feet of an observation well will be affected for approximately 2 weeks. No major land use problems exist at this location, and the testing program is not expected to affect any historical, recreational, or commercial activity. Because the surrounding land use is agricultural and the testing program activities are of short duration, only minor aesthetic impact is expected.

\section{3 .2 .3 Ecology}

A detailed description of the ecology of the Deland site and the region in which it is located may be found in subsection 4.2.2.7. 
Testing at this site will involve the disturbance of agricultural land and approximately 1 acre of woodland. The disturbance of this small amount of woodland is not expected to significantly affect the population of any plant or animal species. Any use of the test area by an endangered species appears highly unlikely. No ecologically unique area is known to exist within 5 miles of the test area.

\section{3 .3 Media}

\subsubsection{Geologic Considerations}

A discussion of the geologic conditions present at the Media site is presented in subsection 4.2 .3 .2 .

The data from 63 wells were used as control to prepare the structure contour map. No further structure test wells are required at the Media site. The testing program does, however, require two injection-withdrawal wells 2070 feet deep, three reservoir observation wells 2180 feet deep, and one caprock observation well 1900 feet deep. Figure 5-3 locates these propnsed well sitcs.

The time required to develop a test air bubble of approximately $1 \times 10^{9}$ cubir fept, using an injoction pressure of 100 psi over discovery pressure, is approximately 5.6 months. 


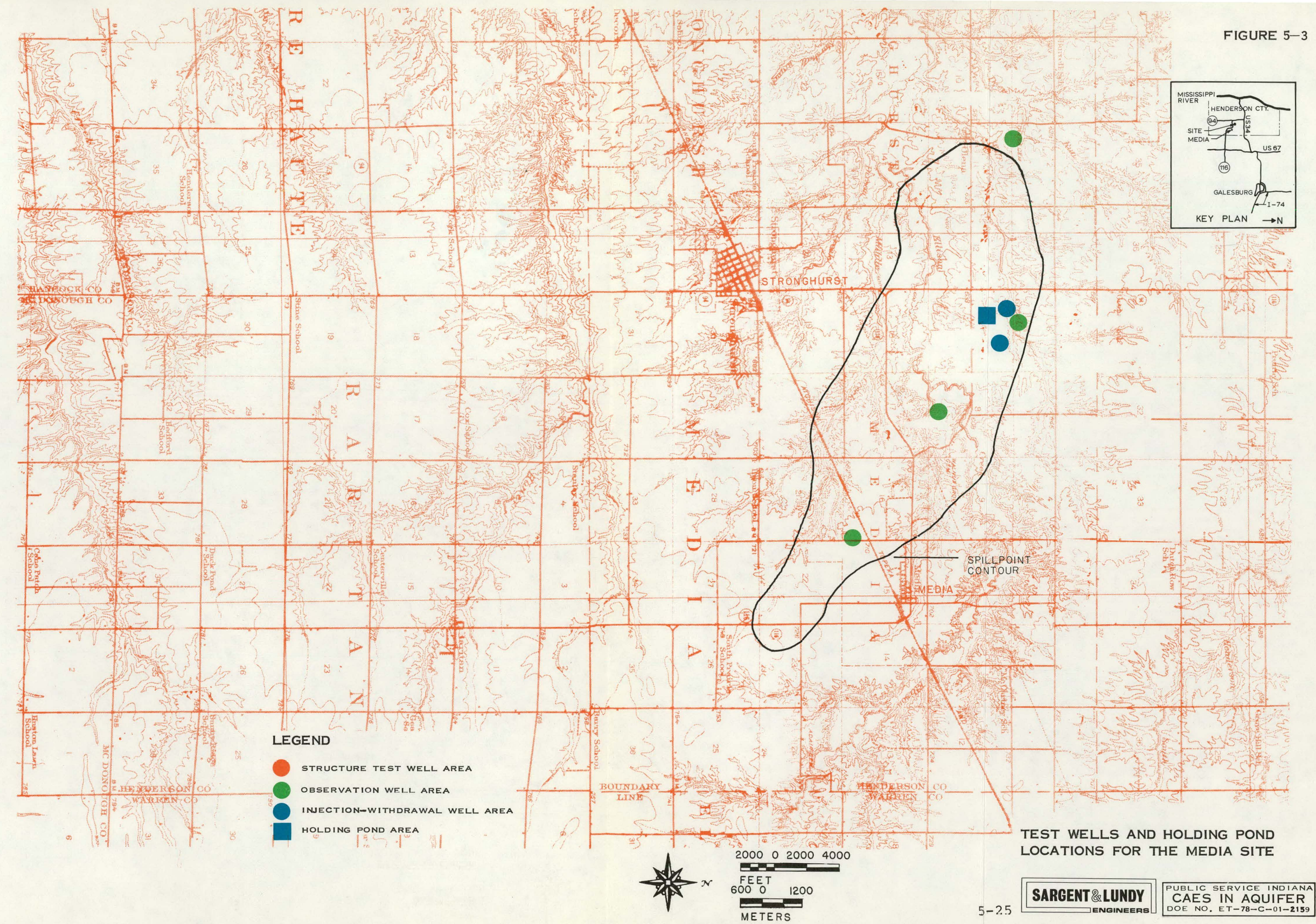




\section{THIS PAGE}

\section{WAS INTENTIONALLY \\ LEFT BLANK}




\subsubsection{Cultural Resources}

Since only six wells and one holding pond are required for the testing at the Media site, the total amount of cropland disturbed (approximately 10 acres) should be very small

and should have no significant impact on agricultural production in the area. One well is on pastureland, one is on woodland, and the rest are on cropland. The holding pond, one observation well, and two injection wells are located in a cluster near the intersection of Highway 94 and a county road. This cluster of wells is located on cultivated cropland within 1000 feet of seven residential structures. The major impact to residential structures should be in this vicinity. Two of the remaining three observation wells are located within 1000 feet of a residential structure. Other than the noise impact on residences, the testing program should present no major land use problem nor will the wells affect any culturally significant activity. No historical, recreational, commercial, or industrial facilities should be affected by the testing program. Since the area is primarily rural and agricultural and the testing program I activities are of short duration, only minor aesthetic impact is expected on surrounding areas.

\section{3 .3 .3 Ecology}

A detailed description of the ecology of the Media site and the region in which it is located may be found in Subsection 4.2.3.7.

Testing at this site will involve the disturbance of agricultural land and approximately 1 acre of woodland. Noise from testing activities may cause some animals to leave 
nearby wooded areas temporarily. The disturbance of this small amount of woodland is not expected to significantly affect the population of any plant or animal species, even though extensive use of the test area by an endangered species is possible. No ecologically unique area is known to exist within 5 miles of the test area.

\subsubsection{Parnell}

\subsubsection{Geologic Considerations}

A discussion of the geologic conditions present at the Parnell site is presented in Subsection 4.2 .4 .2 .

The data from 41 wells were used as control to prepare the structure contour maps. Because of the locations of these wells, no further structure test wells are required at the Parnell site. The large arcal extent of the parncll site, however, requires four injection-withdrawal wells 2500 feet deep, four reservoir observation wells 2640 feet deep, and one caprock observation well 2225 feet deep. Figure 5-4 locates these proposed well sites.

The time required to develop a test air bubble of approximately

$1 \times 10^{9}$ cubic feet, using an injection pressure of 100 psi over discovery pressure, is approximately 2.1 months. 


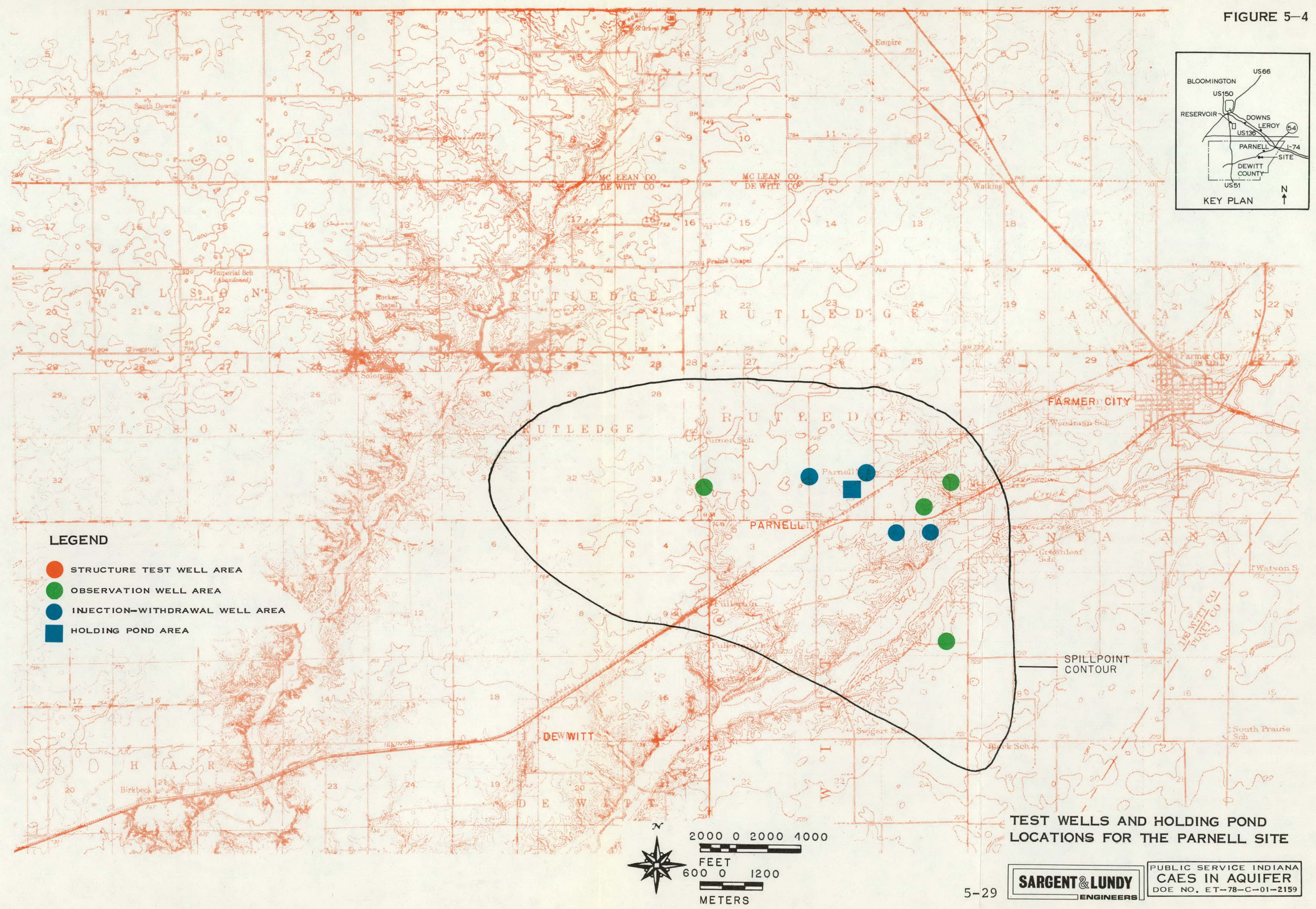




\section{THIS PAGE}

WAS INTENTIONALLY

LEFT BLANK 


\subsubsection{Cultural Resources}

Only nine wells and one holding pond are required for the testing program at the Parnell site. One well is on woodland area, one is on pastureland, and the rest are on cultivated cropland. The amount of cropland disturbed for the testing program (approximately 12 acres) should not have any significant effect on agricultural production in the area. Only two residential structures are within 1000 feet of injection-withdrawal or observation wells and may therefore be affected by noise. One injection well location is on the Lake Clinton state Recreational area and another is adjacent to the recreation area, which will result in negative aesthetic impact. No historical, archeological, institutional, or any other cultural activity should be affected by the testing program.

\subsubsection{Ecology}

A detailed description of the ecology of the Parnell site and the region in which it is located may be found in subsection 4.2.4.7.

Testing at this site will involve the disturbance of agricultural land and approximately 1 acre of woodland. Noise from testing may cause some animals to leave nearby wooded areas temporarily. The disturbance of this small amount of woodland is not expected to significantly affect the population of any plant or animal species, even though some use of the test area by an endangered species is possible. No ecologically unique area is known to exist within 5 miles of the test arca. 


\section{3 .5 Brookville}

\subsubsection{Geologic Considerations}

A discussion of the geologic conditions present at the Brookville site is presented in Subsection 4.2.5.2.

The data from 21 wells were used as control to prepare the structure contour maps. To properly delineate the structure, 12 additional structure test wells drilled to a depth of 760 feet are required. The testing program also requires two injection-withdrawal wclls 830 feet deep, two reservuir observation wells 940 feet deep, and one caprock observation well 622 feet deep. Figure 5-5 locates these proposed well sites.

The time required to develop a test bubble of approximately $1 \times 10^{9}$ cubic feet, using an injection pressure of $100 \mathrm{psi}$ over discovery pressure, is approximately 14.5 months.

\subsubsection{Cultural Resources}

The testing program at the Brookville site requires 17 wells and one holding pond. One well is on pastureland, one is on woodland, and the rest are on cultivated cropland. Since 12 of the wells are structure test wells, and disturbance of the area around these wells will last only for a relatively short time, the effect on cropland and agricultural production in the area should be very little. Approximately 14 acres of cropland will be disturbed. This temporary loss of productive land should have no significant 


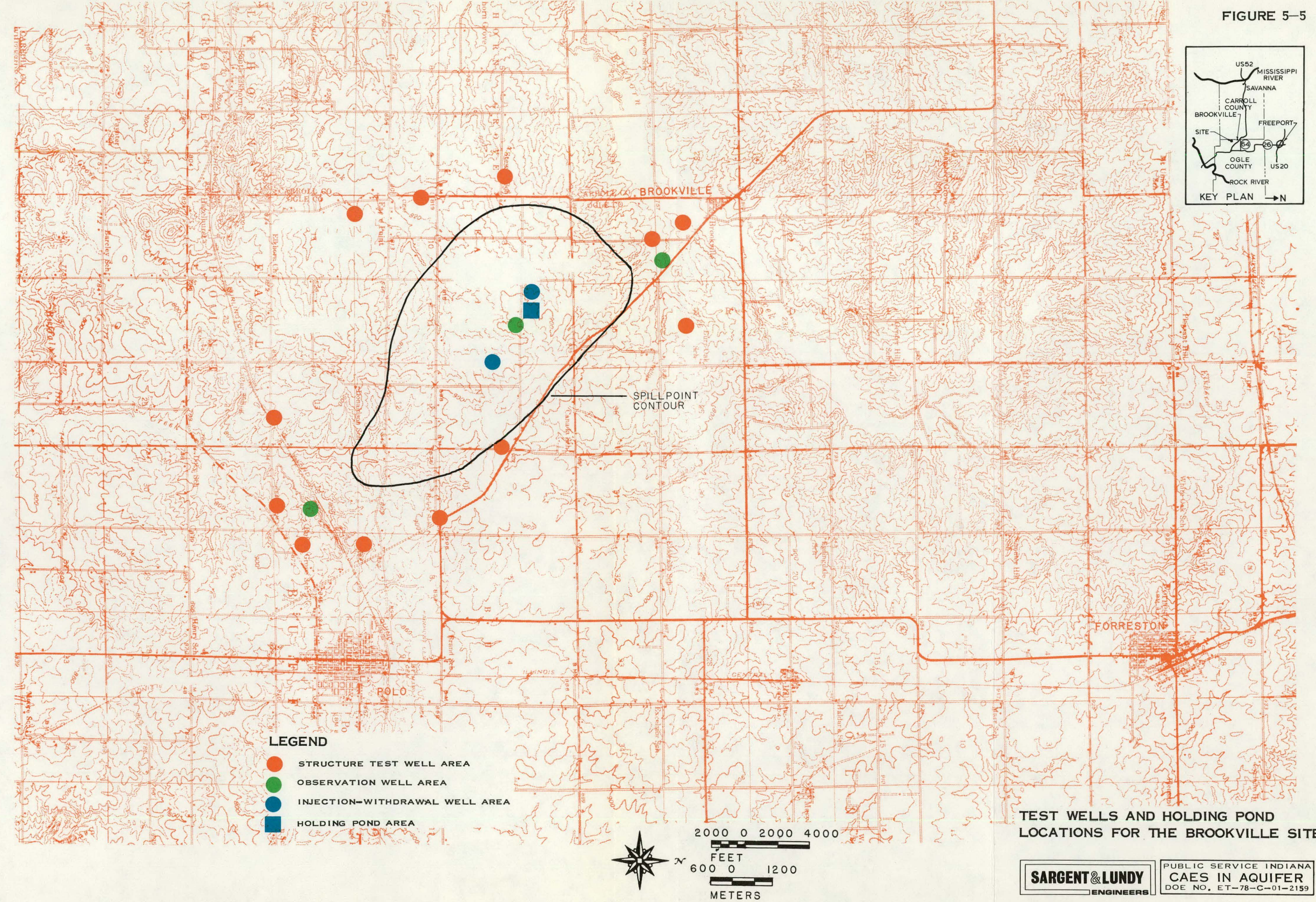


THIS PAGE

WAS INTENTIONALLY

LEFT BLANK 
impact on agricultural production in the area. The major effect of the testing program will be its impact on residential structures, 18 of which are within 1000 feet of some well site. The overall impact is reduced because 10 of these houses are close to the short term structure test wells and therefore will not be affected for very long. Two structure test wells are within a mile of Eagle Point, which has a school and residential structures listed on the ogle County Historical Society Register. These should be the only two wells that present a negative aesthetic impact, but the effect will be small because the drilling activity is expected to last only 1.5 weeks per well. The remaining 15 wells should have little aesthetic impact on the surrounding area. No recreational, commercial, or industrial activities should be affected by the testing program.

\section{3 .5 .3 Ecology}

A detailed description of the ecology of the Brookville site and the region in which it is located may be found in Subsection $4 \cdot 2 \cdot 5.7$.

Testing at this site will involve the disturbance of agricultural land and approximately 1.3 acres of woodland. Noise from testing activities may cause some animals to leave nearby wooded areas temporarily. The disturbance of this small amount of woodland is not expected to significantly affect the population of any plant or animal species, even though some use of the test area by an endangered species is possihle. No ecologically unique area is known to exist within 5 miles of the test area. 


\subsubsection{Fishhook}

\subsubsection{Geologic Considerations}

A discussion of the geologic conditions present at the Fishhook site is presented in Subsection 4.2.6.2.

The data from 71 wells were used as control to prepare the structure contour maps. Because of the locations of these wells, no further structure test wells are required at the Fishhook site. The large areal extent and flat structure of the Fishhook site, however, requires six injection-withdrawal wells 1210 feet deep, four reservoir observation wells 1280 feet deep, and two caprock observation wells 940 feet deep. Figure 5-6 locates these proposed well sites.

'I'he time required to develop an air bubble of approximately $1 \times 10^{9}$ cubic feet, using an injection pressure of 100 psi over discovery pressure, is approximately 2.8 months. The site may, however, be unusable for a testing program because the flatness of the structure may cause the air to spread over too large an area.

\subsubsection{Cultural Resources}

Although the Fishhook site is large, the effect of the testing program should not be severe since only 12 wells and one holdina pond should be required. Sume of the nine residential structures that are within 1000 feet of well sites are likely to be affected by more than one well. All the wells needed at Fishhook are either observation or injection wells and have 


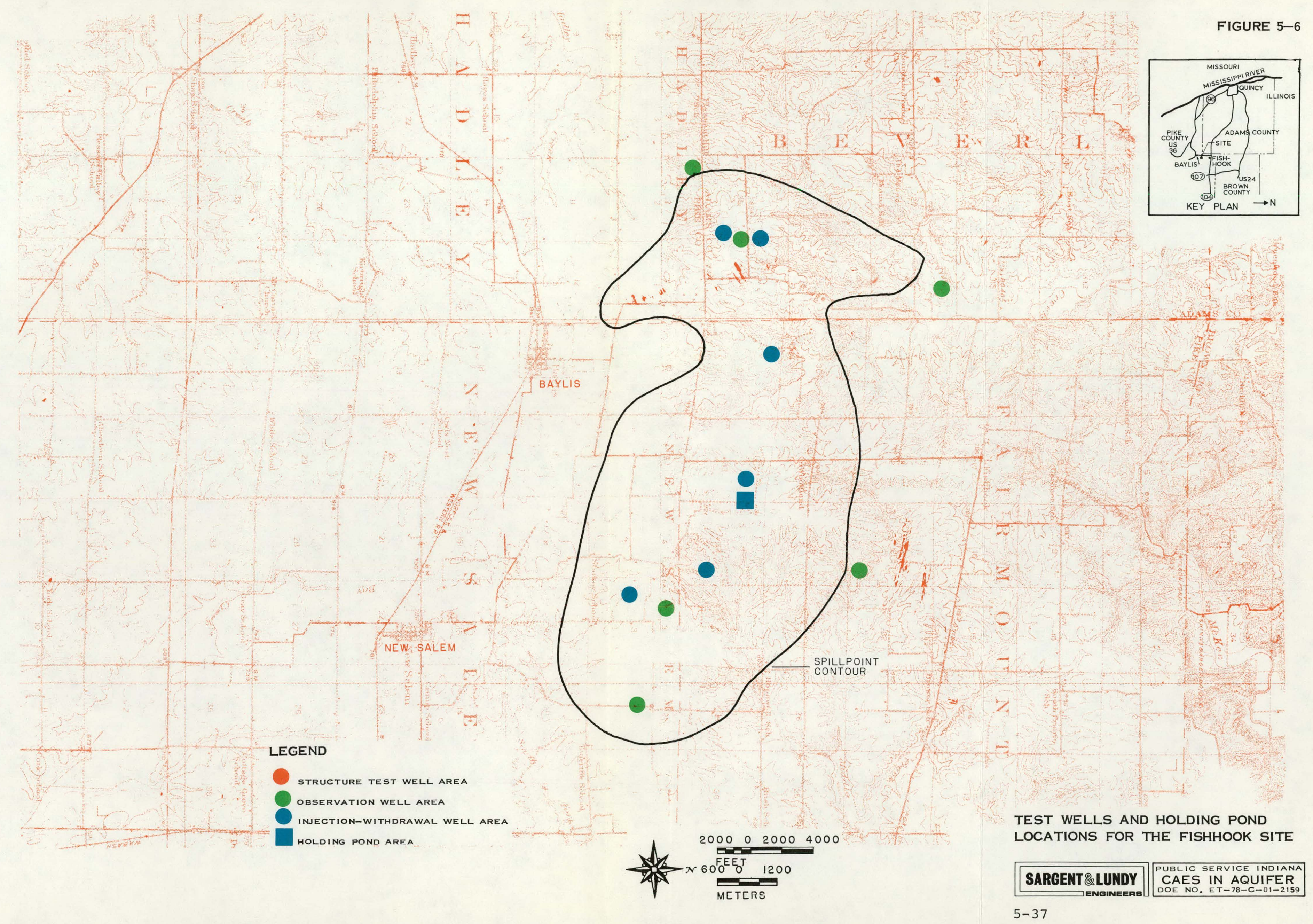


THIS PAGE

\section{WAS INTENTIONALLY LEFT BLANK}


therefore been evaluated for longer term effects than structure test wells. Approximately 25\% of the wells are located on pastureland or woodland and the remainder on cropland. Since only 14.1 acres of cropland will be temporarily disturbed, the disruption of cultivated cropland should be small, and the testing program should have no significant impact on agricultural production in the area. The testing program should present no major aesthetic impact on the surrounding rural area. There are no historical, institutional, commercial, industrial, or recreational activities that could be affected by the testing program.

\section{$5.3 .6 .3 \quad \underline{E c o l o g y}$}

A detailed description of the ecology of the Fishhook site and the region in which it is located may be found in subsection 4.2.6.7.

Testing at this site will involve the disturbance of agricultural land and approximately 5.2 acres of woodland. Noise from testing activities may cause some animals to leave nearby wooded areas temporarily. The disturbance of this small amount of woodland is not expected to significantly affect the population of any plant or animal species, even though extensive use of the test area by an endangered species is possible. No ecologically unique area is known to exist within 5 miles of the test area. 
5.3 .7 Toulon A

5.3.7.1 Geologic Considerations

A discussion of the geologic conditions present at the Toulon A site is presented in subsection 4.2.9.2.

The data from 11 wells were used as control to prepare the structure contour maps. To properly delineate the structure, nine additional structure test wells drilled to a depth of approximately 860 feet are required. The testing program also requires two injection-withdrawal wells approximately 1290 feet deep, two reservoir observation wells 1450 feet deep, and one caprock observation well 1130 feet deep. Figure 5-7 locates these proposed well sites.

The time required to develop a test bubble of approximately $1 \times 10^{9}$ cubic feet, using an injection pressure of 100 psi over discovery pressure, is approximately 29.8 months.

\subsubsection{Cultural Resources}

The 14 wells and one holding pond required for the testing program at Toulon A should present no significant loss of dyricultural lands. Approximately 13 acres of agricultural land will be temporarily disturbed. One well is located on pastureland, one is on woodland, and the rest are on cultivated cropland. Since nine of the wells are structure test wells, the minor disruption of agricultural activity should only be for a relatively short time. Eight of the wells 


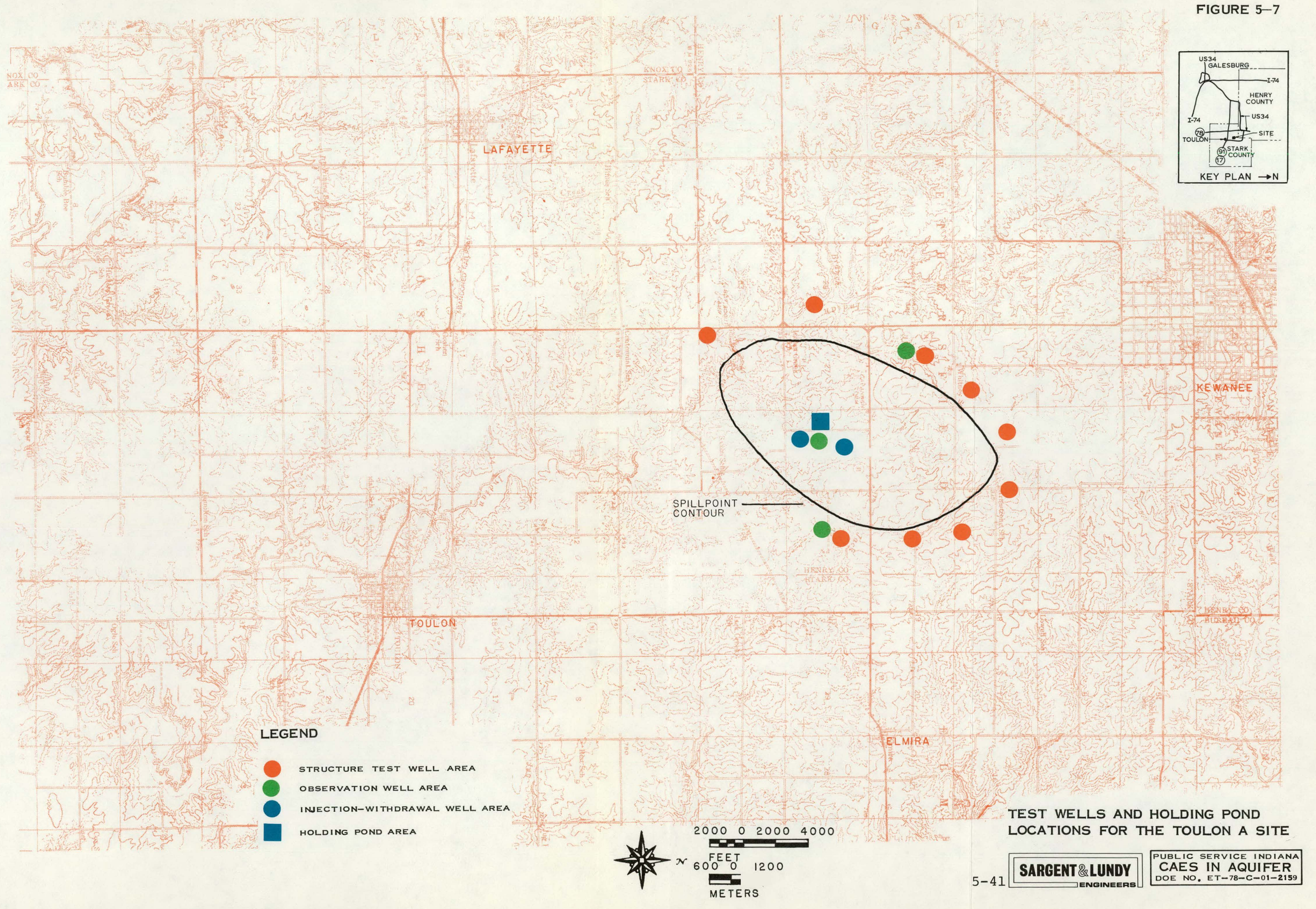


THIS PAGE

\section{WAS INTENTIONALLY LEFT BLANK}


are within 1000 feet of residential structures. The

nine structure test wells should have little impact for a relatively short time. The one residential structure located close to an injection-witharawal well will be affected for about 2 weeks during drilling and may be affected for a longer period during the aquifer pumping and air injection testing. The major activity in the area on which the testing program will have an impact is Black Hawk College, a 2-year community college. One structure test well is located within 1500 feet of the college and three others (two structure test and one observation) are located within a mile. Negative reaction from the college community to the testing program may be expected. The site is in a rural agricultural area and should have little aesthetic impact on the surrounding area. The testing program should not affect any historical, recreational, commercial or industrial activities:

\section{3 .7 .3 Ecology}

A detailed description of the ecology of the Toulon A site and the region in which it is located may be found in Subsection 4.2 .9 .7 .

Testing at this site will involve the disturbance of agricultural land and approximately 0.3 acre of woodland. Noise from construction activities may cause some animals to leave nearby wooded areas temporarily. The disturbance of this small amount of woodland is not expected to significantly affect the population of any plani or animal species, even though some use of the test area by an endangered species is possible. No ecologically unique area is known to exist within 5 miles of the test area. 


\subsection{RESULTS}

The desirability of conducting a testing program at one of the final sites was evaluated for three groups of characteristics: geologic, economic, and environmental. Composite ratings for these characteristics for each of the seven final sites are shown in Table 5-1. Since none of the sites received a rating of loss than three for any of the characteristics, it was concluded that all seven of the final sites appeared suitable for the testing program.

'l'he overall ratings for the geologic characteristics of the sites ranged from 5 to 3 . The four highest rated sites Wapella East, DeLand, Media, and Parnell - had higher scores because they had more and better quality geologic information available than the other sites. Wapella East and Media received a slightly lower rating (4) than DeLand and Parnell because they would require more time to develop a test air bubble. The remaining threp sites - Brookville, Fishhook, and Toulon A have unproven or questionable caprock integrity because of insufficient information. Brookville and Toulon A each require a significant amount of time to develop a test bubble: 14.5 months and 29.8 months respectively. Fishhook has a less desirable aquifer than some of the other final sites because its low structural closure causes the aquifer to be very thin and wide. Since none of the seven final sites received a rating of less than 3 , however, all of the sites are considered to have suitable aquifer characteristics for a testing program. 
TABLE 5-1

SITE SUITABILITY EVALUATION

OF THE FINAL SITES FOR THE FIELD TESTING PROGRAM

\begin{tabular}{|c|c|c|c|c|c|c|c|}
\hline CHARACTERISTICS & $\begin{array}{l}\text { WAPELLA } \\
\text { EAST }\end{array}$ & DELAND & MEDIA & PARNELL & BROOKVILLE & FISHHOOK & TOULON A \\
\hline Geologic & 4 & 5 & 4 & 5 & 3 & 3 & 3 \\
\hline Economic & 5 & 4 & 5 & 4 & 5 & 3 & 3 \\
\hline Environmental & 5 & 4 & 3 & 3 & 3 & 3 & 3 \\
\hline
\end{tabular}


The estimated present day costs for the testing program at the seven final sites are presented in Table 5-2. The major cost items that contributed to the cost differential of approximately $\$ 1,100,000$ were (a) the depth and number of injection-withdrawal and observation wells and (b) the time required to develop a tegt bubble. The Wapella East site has the lowest estimated cost because it has relatively low estimated costs for both these major cost items. Some other siles ladve much lower costs for one of the major items but much higher costs for the other. For example, the Brookville site has the lowest cust for the structure test wells and injcction-withdrawal and observation wells because of the shallow depth of the wells, even though the site requires the most number of wells (18), but it is not the least expensive site because of its relatively high cost for initial air injection due to the long injection period (14.5 months). Toulon $A$ also has shallow wells but because of the even longer amount of time required for air injection (29.8 months), it is the most costly site. The overall rating for the economir characteristics of the sites is a 5 lus the three sites with estimated costs of less than $\$ 2.0$ million, 4 for the two sites with estimated costs of between $\$ 2.0$ and $\$ 2.5$ million, and 3 for the two sites with estimated costs of between $\$ 2.5$ and $\$ 3.0$ million.

The overall ratings for the environmental characteristics of the sites range from 5 through 3 . None of the sites received 
TABLE 5-2

\section{ESTIMATED COST OF DRILLING}

\section{AND TESTING PROGRAM}

\begin{tabular}{|c|c|c|c|c|c|c|c|c|c|c|}
\hline \multirow{2}{*}{ SITE } & \multicolumn{2}{|c|}{ STRUCTURE TEST WELLS } & \multicolumn{3}{|c|}{$\begin{array}{l}\text { RNECTION-WITHDRAVAL AND } \\
\text { OBSERYMTION WELLS }\end{array}$} & \multirow{2}{*}{$\begin{array}{c}\text { WATER } \\
\text { PUNRING } \\
\text { TEST } \\
\end{array}$} & \multirow{2}{*}{$\begin{array}{l}\text { IABORATORY } \\
\text { TESTING } \\
\end{array}$} & \multirow{2}{*}{$\begin{array}{l}\text { INITIAL. } \\
\text { AIR } \\
\text { INJECTIOU }\end{array}$} & \multirow{2}{*}{$\begin{array}{l}\text { RESERVOIR } \\
\text { CONSULTANT }\end{array}$} & \multirow{2}{*}{$\begin{array}{l}\text { TOTAL } \\
\text { ESTIMATED } \\
\text { COST }^{\mathrm{a}}\end{array}$} \\
\hline & DRULLING & $\begin{array}{l}\text { GEOPHYSICAL } \\
\text { LOGGING }\end{array}$ & $\frac{\text { DRILLI }}{7-\text { INCH }}$ & $\frac{9 \text { WELS }}{41 \text { ISINCH }}$ & $\begin{array}{l}\text { GEOPHYSICAL } \\
\text { LOGGING }\end{array}$ & & & & & \\
\hline Wapella East & $\$ 67,300$ & $\$ 5,000$ & $\$ 376,500$ & $\$ 545,800$ & $\$ 35,000$ & $\$ 270,000$ & $\$ 44,500$ & 437,500 & $\$ 30,000$ & $\$ i, 811,600$ \\
\hline Brookville & $\$ 116,900$ & $\$ 20,000$ & $\$ 130,200$ & $\$ 192,300$ & $\$ 35,000$ & $\$ 270,000$ & $\$ \$ 4,500$ & $\$ 1,074,300$ & $\$ 30,000$ & $\$ 1,913,200$ \\
\hline Media & None & None & $\$ 324,700$ & $\$ 648,800$ & $\$ 42,000$ & $\$ 270,000$ & $\$ 53,500$ & 575,300 & $\$ 30,000$ & $\$ 1,944,000^{b}$ \\
\hline Deland & $\$ 300,000$ & $\$ 20,000$ & $\$ 400,000$ & $\$ 580,000$ & $\$ 35,000$ & $\$ 270,000$ & $\$ 44,500$ & 398,030 & $\$ 30,000$ & $\$ 2,077,500$ \\
\hline Parnell & None & None & $\$ 784,300$ & $\$ 779,900$ & $\$ 56,000$ & $\$ 270,000$ & $\$ 53,500$ & 384,000 & $\$ 30,000$ & $\$ 2,357,700$ \\
\hline Fishhook & None & None & $\$ 569,400$ & $\$ 538,100$ & $\$ 84,000$ & $\$ 270,000$ & $\$ 62,500$ & $\$ 1,157,300$ & $\$ 30,000$ & $\$ 2,711,300$ \\
\hline Doulon A & $\$ 99,200$ & $\$ 15,000$ & $\$ 202,350$ & $\$ 309,800$ & $\$ 35,000$ & $\$ 270,000$ & $\$ 44,500$ & $\$ 1,909,900$ & $\$ 30,000$ & $\$ 2,915,700$ \\
\hline
\end{tabular}

\footnotetext{
Totals are rounded to nearest $\$ 100.00$
}

bosts does not reflect the assumption that existing infection-rithdrawal and observation wells may be present at the Media site. If these wells are still inplace and could be used for the infection pras, then the cost for the testing prograli would be near the cost for the air

infection phase. The cost is exclusive of any fees NIGAS may require for their data. 
a rating of less than 3, which indicates that the environmental impacts from a testing program at any of the sites were considered negligible. Wapella East, which has an overall environmental rating of 5 , received individual ratings of 5 for all of the cultural resources and ecology criteria diacusged in Section 5.2. The Deland sile recelved an overall rating of 4 primarily because a testing program would disturb more residences (7) at this site than at the Wajella East s1te. 'l'his number, however, was not considered significant compared to the large number of wells required (17). The remaining five siles all recelved an overall environmental rating of 3 . Three of the five sites - Media, Toulon A, and Fishhook - are similar because testing at each would disturb between 8 and 12 residences, have some minor impact upon ecologically valuable habitats, and have a somewhat greater potential for affecting endangered species. The major concern at the Parnell site is that the testing program would disturb the state recreational development on the shores of Lake clinton. The Brookville site would have the most severe impact on residences since it would require 17 wells that would be in close proximity to a total of 18 residences.

In conclusion, the impacts associated with the testing program do not appear to vary significantly among the sites. No sites. were eliminated from consideration due to unsuitability for the testing program. As a result, the ranking of the seven final sites remains the same as that determined during the initial evaluation of the potential sites (see subsection 4.3). 


\section{REFERENCES}

1. U.S. Fish and Wildife Service. "Endangered and Threatened Wildlifc and Plants." Federal Register, Vol. 44, No. 12, 1979 , p. 3636-54.

2. Illinois Department of Conservation. "IIlinois List of Endangered and Threatened Vertebrate Species." Springfield, Illinois, 1979, Leaflet. 


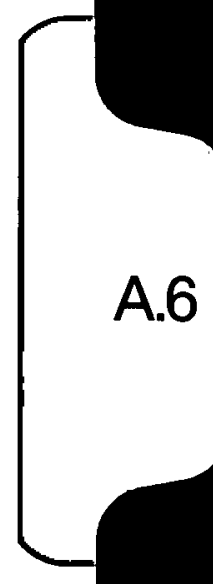


C.AF.S-T2

Chapter 6

BIBLIOGRAPHY

This chapter inriudes reference materials not cited in the text.

Bi-State Metropolitan Planning Comuission. Bi-stat.e Region. "Regional Land Use - 1975." Rock Island, Illinois, undated. Map.

Blade, M., Regional Planner, West Central Indiana Economic Development District, Inc., Terre Haute, Indiana. Letter of Februaiy 5, 1979, to S. A. Hallaron, Cultural Resource Analyst, Sargent \& Lundy, Chicago, Illinuis.

Flemming, J.S., National Register Assistant, Historic Sites Division, Illinois. Letter of January 31, 1979, to S. A. Hallaron, Cultural Resource Analyst, Sargent \& Lundy, Chicago, Illinois.

General Services Administration. National Archives and

Records. Federal Register. Washington, D.C.: Government Printing office, 1979 .

Glenn, L. B., Vice President, Public Affairs, Historic New Harmony, Inc., New Harmony, Indiana. Letter of February 13, 1979, to S. A. Hallaron, Cultural Resource Analyst, Sargent \& Lundy, Chicago, Illinois.

Illinois Department of Agriculture. Cooperative Crop Reporting service. Illinois Agricultural Statistics, Annual Summary 1977. Springfield, Illinois, undated. Bulletin No. 77-1.

Illinois state Geological Survey. "Oil and Gas Industry in Illinois, 1977." Urbana, Illinois, undated. Map.

Indiana Geological Survey. "Map of Indiana Showing Oil, Gas, and Products Pipelines." Bloomington, Indiana, 1973.

Lawrence, William C. and Assoc. Inc. Physical Factors for planning Report for Ogle County, Illinois. Chicago, Illinois, 1973.

Meents, W. F. "Oil and Gas Industry in Illinois: 1977." Urbana, Illinois: Illinois State Geological Survey, 1977. Map, scale $1: 500,000$.

Mylius, L. A. "Oil and Gas Development Possibilities in East-Central Illinois: Clark, Coles, Douglas, Edgar, and Parts of Adjoining Counties." Urbana, Illinois: Illinois State Geological Survey, 1927. Bulletin 68. 
New Harmony Plan Commission. Comprehensive Plan, New Harmony, Indiana. New Harmony, Indiana, 1974.

Niemann, T., Assistant Planner, Bi-State Metropolitan Planniny Commission, Rock Island, Illinois. Letter of February 9, 1979, to S. A. Hallaron, Cultural Resource Analyst, Sargent \& Lundy, Chicago, Illinois.

The Ogle County Historical Society. "Historical Map of Ogle County." Oregon, Illinois, undated.

Smith, G. C., L. E. Wiles, and W. F. Loscutoff. "Numerical Analysis of Temperature and Flow Effects in a Dry, OneDimensional Aquifer Used for Compressed Air Energy storaye." Ridgeland, Washington: Pacific Northwest Laboratory, Battelle Memorial Institute, 1979. PNL 2546.

Southwestern Indiana and Kentucky Regional Council of Governors. "Existing Land Use and Natural Resources," Evansville, Indiana, 1975. Map.

Statc of Illinols. Department of Business and Economic Development. Economic Profile of the following Counties: Newitt, Edgar, Hendersnn, Honry, Ogle, Piatt, Pike, and Stark. Springfield, Tllinois: Office of Research and Planning, 1978.

SLále of 111inois. Department of Transportation. "1977 Average Daily Total Traffic." springfield, Illinois, undated. Map.

State of Indiana. Division of Planning. Indiana State Highway Commission. "1975 Traffic Map." Bloomington, Indiana, undated.

U.S. Bureau of the Census. U.S. Department of Commerce. 1975 Population Estimates and Projections: Estimates of the Population of Indiana Counties and Metropolitan Areas (1976 Provisional). Washington, D.C.: Government Printing office, 1977 .

U.S. Bureau of the Census. U.S. Department of Commerce. 1976 Population Estimates and Projections: Estimates of the Population of Illinois Counties and Metropolitan Areas. Washington, D.C.: Government Printing Office, 1979.

U.S. Department of Agriculture. Soil Conservation Service. "Sycamore Trails, Resource, Conservation, and Development Project: Clay, Parke, Putnam, Sullivan, Vermillion and Vigo Counties, Indiana." Maps showing Prime Cropland and Speciality Crop Soils, Historic Sites and Natural Areas, Recreation Developments, Land Use and Ownership, and Existing Industrial Sites and Major Utility Transmission Lines. Washington, D.C.: U.S. Department of Agriculture, 1974. 
U.S. Department of the Interior. Heritage Conservation and Recreation Service. National Register of Historic Places. Washington, D.C.: Government Printing Office, 1978 .

U.S. Environmental Protection Agency. Compilation of Air Pollutant Emission Factors (Revised). Research Triangle Park, North Carolina: Office of Air Programs, 1972.

U.S. Geological Survey. Topographic maps, 7.5 and 15 minute series for all sites. Various dates.

University of Illinois Agricultural Experiment Station. "Prime Farmland in Illinois:" Urbana, Illinois: U.S. Department of Agriculture, Soil Conservation Service, 1977.

Westinghouse Electric Corporation. Fluid systems Laboratory. "CAESRl Computer Code Listing." West Lafayette, Indiana:

Research and Development Center, 1979.

Ziegler, G., Senior Planner, Western Illinois Regional Council, Macomb, Illinois. Letter of February 20, 1979, to S. A. Hallaron, Cultural Resource Analyst, Sargent \& Lundy, Chicago, Illinois. 
A.A 
Attachment A

SUMMARY OF LITERATURE: EFFECTS OF AIR

INJECTION ON AQUIFER-CAPROCK-WELL SYSTEMS

CONTENTS

Section

A.1 SUMMARY, CONCLUSIONS, AND RECOMMENDATIONS

Page

$A-1$

A. 2 INTRODUCTORY STATEMENT

$A-6$

A. 3 TOPICAL LITERATURE SUMMARIES A-8

A.3.1. Direct References to Compressed Air

Energy Storage and to Underground

Natural Gas storage

A.3.1.1 Introduction

A.3.1.2 Summary of Literature

A.3.1.3 Conclusions

A.3.1.4 List of References Examined

A.3.2 Compressed-Air Injection into Petroleum-

Bearing Reservoir Rocks

A.3.2.1 Definition of Potential Problems

A.3.2.2 Summary of Literature

A.3.2.3 Conclusions and Recommendations

A.3.2.4 List of References Examined

A.3.3 Clay Mineral Destabilization and its

Effects on Reservoir Rocks and Caprocks

A.3.3.1 Definition of Potential Problems

A.3.3.2 Summary of Literature

A.3.3.3 Conclusions and Recommendations

A.3.3.4 List of References Examined

A.3.4 Possible Mechanical Failures in

Reservoir Rocks and Caprocks

A.3.4.1 Definition of Potential Problems

A. 3.4 .2

summary of Literature

A. 3.4 .3

Conclusions and Recommedations

A. 3.4 .4

A. 3.5

List of References Examined

Effects of Oxidation of Iron-Bearing

Minerals and of Steel

A.3.5.1 Definition of Potential Problems

$A-8$

$A-8$

A -9

$\mathrm{A}-14$

$A-14$

$A-14$

A -15

$A-16$

$A-19$

$A-21$

$A-21$

$A-21$

$A-22$

$\mathrm{A}-25$

$A-25$

A-26

$A-26$

A-26

A -27

$A-28$

$A-28$

$A-28$

$A-29$

$A-29$

$\mathrm{A}-30$

A.3.5.4 List of References Examined

A.3.6 Problems of Bacterium and Other

Microorganism Proliferation
$A-31$ 
CONTENTS (Cont'd)

Section

A.3.6.1 Definition of Potential Problems

$A-31$

A. 3.6 .2

Summary of Literature

$A-31$

A. 3.6 .3

Conclusions and Recommendations

$A-33$

A. $3 \cdot 6 \cdot 4$

List of References Examined

$A-34$

A.3.7 Thermil Etresses un well lasings

$A-34$

A.3.7.1 Definition of Potential Problems

$A-34$

A. 3.7 .2

Summary of Literature

A. 3.7 .3

Conclusions and Recommcdations

A.3.7.4 List of References Examined

A.3.8 Environmental Cuncerns and Hazards

A -34

$A-35$

$A=36$

$A-36$

A.3.8.1 Definition of Potential Problems

A- 36

A. $3.8 \cdot 2$

Summary of Literature

A -37

A.3.8.3 Conclusions and Recommendations

A -38

A.3.8.4 List of References Examined

A. 3.9 Miscellaneuus

$A-38$

$A-39$

A.3.9.1 Introduction

A -39

A.3.9.2 Summary of Literature and Commentary

A -39

A.3.9.3 List of References Examined

A- 41

REF EKENC'ES

A -41 


\title{
Attachment A \\ SUMMARY OF 'LITERATURE: EFFECTS OF AIR \\ INJECTION ON AQUIFER-CAPROCK-WELL SYSTEMS
}

\begin{abstract}
A.1 SUMMARY, CONCLUSIONS, AND RECOMMENDATIONS
This section presents a digest of representative literature on selected topics relevant to geologic aspects of compressed-air energy storage (CAES). Emphasis is placed on information useful in predicting performance dild potential problems of reservoir rocks, caprocks, and related portions of well systems. Literature canvasses were organized around the following topics:
\end{abstract}

a. direct references to compressed-air energy storage and to underground natural gas storage. (see Section A.3.1);

b. compressed-air injection into petroleumbearing reservoir rocks and compressed-air testing of natural gas reservoirs (see Section A.3.2);

c. clay mineral destabilization and its effects on reservoir rocks and caprocks (see Section A.3.3);

d. possible mechanical failures in reservoir rocks and caprocks (see Section A.3.4); 
e. effects of oxidation of iron-bearing minerals and of steel (see section A.3.5);

f. problems of bacterium and other microorganism proliferation (see Section A.3.6);

g. thermal stresses on well casings (see Section A.3.7);

h. environmental concerns and hazards (see Section A.3.8); and

i. miscellaneous (see section A.3.9).

The following major conclusions were reached:

a. Since at present there are no functioning CAES aquifer plants, there are no direct data on the operation of this mode of storage. Experience from underground natural-gas storage is probably the best single source for predictions of the overall workings of compressed-air injection, and the technology of enhanced petroleum-recovery is probably the major source of information on specific problems likely to be encountered in air injection.

b. The geometric complexities of bubble growth and the irregular pattern of water expulsion 
in natural-gas storage aquifers are a good model for CAES; the oxidizing environment of CAES, however, is an important source of problems not encountered in the reducing environment of natural gas injection.

c. The potential for problems of permeability loes, environmental. hazards, and possibly corrosion is significantly greater in petroleum-bearing aquifers than in nonpetroleum-bearing aquifers.

d. Clay minerals of reservoir and, possibly, caprocks are potentially susceptible to destabilization in the presence of warm injected air. Fresh water of condensation in contact with clay minerals could provoke alterations, swelling, and loss of permeability under certain conditions. Dehydration of clay minerals could form abrasive clay-dust particles, which even in small amounts are potentially harmful to generator components. Specific mineralogy and distribution of clay minerals could be a more important determinant of clay behavior than the total quantity of clay present. Polymers can inhibit clay swelling. 
e. The literature survey revealed little of direct application to the mechanical failure of rescrvoir/caprocks under projected CAES conditions. Laboratory experiments, however, on the effects of hot air (ventilation) on rock stability are now in progress at the University of Wisconsin at M11waukee. From a limited data base the mechanical failure of reservoir rocks in CAES service does not appear likely.

f. Under certain conditions, the injection of air into pyrite-bearing strata might set off a chain of events in which sulfate ions from oxidized pyrite combine with calcium ions in formation waters to precipitate gypsum that clogs reservoir pores. In cases where pyritiferous shale caprock is in direct contact with reservoir beds, gypsum formation could induce expansive forces in the caprock. Acid solutions derived from the oxidation of pyrite could have deleterious effects on reservoir rocks.

g. The possibility that sulfate-reducing bacteria may survive in the CAES environment, as they do in the oxidizing environment of aquifers undergoing water drive, cannot be dismissed. Unchecked proliferation of sulfate-reducing 
bacteria could result in pore clogging, corrosion, and aquifer contamination.

h. There should be no failure or damage to CAES well casings because of thermal stresses, assuming that injection/withdrawal wells employ petroleum industry technology. Techniques used in drilling oil or gas wells should be readily adaptable to CAES drilling.

i. Explosion hazards and/or air pollution would be a major environmental concern at all CAES sites in depleted petroleum reservoirs. At other sites, potential environmental concerns include bacterial, chemical, or thermal contamination at the air storage aquifer and, if there is caprock leakage, of other aquifers as well.

Based on the preceeding conclusions, the following recommendations are made:

a. A continuing survey of current literature on topics of interest should be maintained with the help of indices such as the Government Index of Publications, the Engineering Index, and geological and petroleum engineering publications. References to actual field or 
laboratory experience (e.g., at the University of Wisconsin at Milwaukee vork) would be particularly valuable.

b. Before any final decision to accept a site is made, a thorough petrographic study of reservoir and caprocks, including microscopic and $x$-ray analysis, should be undertaken. Detailed mineralogy and distribution of clay minerals and pyrite would be of particular importance.

c. Reservoirs in depleted oil field should be considered a poor choice until proven otherwise.

d. Applications for permits must address the possibilities of thermal, chemical, or biological contamination of aquifers and the possibility of atmospheric pollution.

\section{A.2 INTRODUCTORY STATEMENT}

One of the major unknown elements in the feasibility evaluation of CAES aquifer sites is the potential effect of air injection on the aquifer-caprock-well system. As a first step in assessing the nature and magnitude of such effects, a literature search of selected potentially relevant topics was undertaken. Rather than attempting an exhaustive canvass, a representative sampling of literature was sought. A summary of the more noteworthy points discovered is the subject of this part of the report. 
The choice of relevant subjects to research entailed a considerable measure of judgment. Emphasis was placed on problems controlled by geological conditions. Since the development of the CAES concept is relatively new and there are no existing aquifer-reservoir plants from which to draw data, it was necessary to use theoretical models of airinjection effects, derived in part from experience of related technologies (e.g., underground natural gas storage, petroleum recovery), to forecast problems that might arise during the operation of a CAES plant. Once potential problems were forecast, books and periodicals were identified that were likely to contain conceptual material on CAES or field or laboratory data on other subjects adaptable to CAES studies. The literature on enhanced recovery of petroleum was most applicable to the CAES study.

To aid in the identification of literature sources, the computerized literature surveys Geoarchive, Energyline, and Compendex were run at John Crerar Library (Illinois Institute of Technology, Chicago), but they yielded little additional information. 


\section{A.3 TOPICAL LITERATURE SUMMARIES}

The most important literature search objectives were to locate direct references to the geological aspects of CAES aquifer storage and to the closely related topic of underground natural gas storage. The next goal was a canvass of a wide variety of sources for data relevant to the potential effects of air injection. For each of the topics considered, literature summaries and conclusions and recommendations are presented in the following pages. Each tópical summary also includes a list of references. 'l'he complete citations are given in section A.4.

\section{A.3.1 Direct References to Compressed Air Energy Storage and to Underground Natural Gas Storage}

\section{A.3.1.1 Introduction}

Literature on compressed-air energy storage and underground natural gas storage was scanned to develop an outline of the air-injection process within which more specific problems could be addressed. Gas storage references were considered along with direct references to CAES because gas storage technology is probably the major source of information the functioning of the complete compressed-air injection system. Noteworthy items in the CAES/natural gas literature with relevance to specific topics considered are discussed in the appropriate topical sections. 


\section{A.3.1.2 Summary of Literature}

Good general treatments of CAES are presented by Ayers and Strong (I), Bervig and Pinker (2), Fleury ( $\underline{3}$ ), Harbol (4), Katz and Lady (ㅁ), Rogers and Allen ( $\underline{6})$, and most comprehensive of all, General Electric/ERDA (7). Bond () and Buschbach and Bond (9) provide excellent summaries of underground natural gas storage in aquifers, particularly in the Illinois Basin of Illinois.

Ayers and Strong (1) discuss mined cavern, dissolved salt cavern, depleted oil reservoirs, and aquifer modes of storage and conclude that aquifer storage is best because it is the most inexpensive, as shown by the experience of the natural gas storage industry. A minimum volume of $10^{7}$ to $10^{9}$ ft $^{3}$ is needed for compressed air aquifer storage. Air storage reservoirs can tolerate greater leakage than would be permissible for natural gas storage. A large air bubble is necessary to minimize undesirable humidity-pressure-temperature and volume changes near intake wells. Displaced air will not compress aquifer water ad infinitum; some compression of solid grain structure will occur. Following the displacement of groundwater, a temperature equilibrium between air and solids in the aquifer is established.

Bervig and Pinker (2) considered candidate CAES sites in the Kansas City area. They determined that aquifer storage requires $10 \%$ porosity, over 200 millidarcies permeability, and $1.60 \times 10^{8} \mathrm{ft}^{3}$ storage volume. The 
shape of the ideal reservoir is an inverted saucer of 2:1 length-width ratio, reservoir thickness of 150 feet and side slopes of $0.2: 1$. Depth range should be between 750 and 3000 feet; caprock permeability should not exceed $10^{-5}$ millidarcies.

The article by Fleury (ㅁ) (in French) concentrates on underground mined storage, which is considered the best mode of storage (at least for France). He feels that aquifer storaqe poses qrave problems because of (a) the large number of intake wells necessary to maintain needed air flow in the face of near-well porosity problems, (b) oxidation, (c) blockage by growth of microorganisms, and (d) the lack of knowledge of air behavior in underground storage. Other authors address these problems, as related, in following sections of this report. The Fleury paper, however, contains a good summary table of advantages and disadvantages of different modes of storage. Excavated granite caverns are considered the best type of storage. The French propose to construct a CAES mined cavern in Brittany during the 1980's.

The General Electric/ERDA (ㄱ) report is a joint effort of the General Electric Company, Fenix and Scisson, Inc., and United Engineers and Constructors. It is an extremely thorough and comprehensive review of CAES and includes a detailed conceptual design of an aquifer storage plant, 
using the Brookville Dome in Illinois as an hypothetical site, and of an excavated cavern storage plant using a hypothetical site near sykesville, Maryland.

The Harbol (4) report is a general paper noting that the concept of aquifer storage is yet to be proven. The paper by Hobsen et al. $(\underline{10})$ is a survey of potential sites in California, including aquifer sites and depleted oil/gas fields.

The Katz and Lady (므) work is the only comprehensive textbook available dealing with the subject of compressed air storage. The presentation deals with the fundamental principles of underground storage and their application to compressed air storage. Several example designs and calculations are covered including a conceptual design of an aquifer storage plant using the Media field in Illinois.

Howells' (11) paper addresses cavern storage. The author points out that even minute quantities of mineral salts can cause corrosion problems if they enter the well system. This could be of significance in aquifer storage. $\dot{A}$ paper written by Kartsounes (12) and another one by Kim and Kartsounes (13) are concerned with details of turbine systems with CAES aquifer systems. An article by Korsmeyer (14) considered underground caverns only. A paper by Park et al. (15) is an economic and cost study of accelerating research activities of application to electric utilities. 
The Rogers and Allen paper ( $\underline{6})$ is a conceptual article on underground hydrostorage and CAES devoted to equipment, plant arrangement, and economics. No information is given on aquifer storage. Smith and wiles (16) report on a romputer simulation study of the effect of variuus reservoir parameters on CAES operation.

Adaressing natural gas storage in aquifers, Bunl (모 makes a number of statements of interest to CAES. He describes the following tools of exploration for aquifer gas-ctorage reservoirs (particularly in the lllinois Basin): surface geology, coal structure maps, shallow structure tests, oil and gas tests, water wells, geophysics, and test holes in aquifers. The following tests of caprocks are also important: core analysis, differences in water composition and/or head above and below caprock, pumping tests, and observation wells in gas-filled fields. All of these tools and tests can be applied to CAES. Dond cautions that inhomogeneities above and below caprocks must have existed through "geoloqic time" if they are to serve as reliable indicators of caprock integrity and that entry of gas into a caprock is controlled by head differences across the caprock as well as by threshold pressure. The shape of the gas "bubble" can be highly irregular and depart greatly from the ideal owing to horizontal and vertical variations in reservoir rock permeability. Other causes of anomalous shape and behavior of the gas bubble can be 
attributed to gravity differences in waters of varying densities or to hydrodynamic conditions evidenced by phenomena such as a tilled gas/water interface. In addition to solid gas hydrates, "water-walls" and "foam-walls" have been proposed as seals for reservoirs having no structural closure.

Buschbach and Bond (9) make the important point that fresh water aquifers are not used for gas storage in Illinois because they are too valuable as sources of potable water. In discussing the effects of gas injection, the authors note that not all water in the aquifer is displaced at the same time or uniformly in all directions; pockets of residual water are left behind. As gas is injected, the surrounding water and rock are compressed, but several miles from the reservoir water pressure and density are practically unchanged. Normal gas injection pressures are about 0.55 psi/ft of depth, but pressures as high as $0.7 \mathrm{psi} / \mathrm{ft}$ of depth have been used. Initial fluid pressure must be also considered. Permeability to gas can be estimated from field water-pressure tests. Also of interest is that high withdrawal rates from gas storage, compared with natural gas and oil fields, render capillary effects less important but tend to make movement of the gas/water interface more complicated because of the cyclic nature of withdrawal. Presumably both of these trends would be even more marked in CAES. 


\section{A.3.1.3 Conclusions}

Much of the experience accumulated in the development of aquifer storage for natural gas seems to be applicable to CAES. The geometric complexities of bubble growth and irregularity of water expulsion of natural gas storaye aquifers are a good model for CAES; likewise, the techniques for exploring and testing reservoirs is also applicable. As sliuwn ln the following portinns inf this report, the oxidizing environment that air-injection creates is an important cause of probleills not encountered in the reducing environment of natural gas injection.

\section{A.3.1.4 List of References Examined}

Ayers and Strong ( $(\underline{1})$, Bervig and Pinker (2), Bond ( 8 ), Buschbach and Bond (9), Day, Alff, and Jarvis (17), Engineering News Record (18), Fleury (ㅁ) , General Electric/ERDA (ㄱ) , Giramonti (19), Harboe (4)), Hobson et al. (10), Howells (11), Kartsounes (12), Katz and Lady (ㅁ) , Kim and Kartsounes (13), Korsmeyer (14), Lady and Katz (20), Park et al. (15), Rogers and Allen (6), Smith and Wiles (16), Stottlmyre et al. (21), and Despois and Nougarède (22).

\section{A.3.2 Compressed-Air Injection into Petroleum-Bearing} Reservoir Rocks 


\section{A.3.2.1 Definition of Potential Problems}

The topic of compressed air injection into petroleum reservoir rocks is of great importance because it is a source of information on what actually does happen when air is pumped into the ground rather than what might be inferred to happen from indirect data. Obviously, experience from compressed air injection into actual oil fields would be especially relevant to CAES development in abandoned oil fields but some ideas might be applied to non-petroliferous aquifer sites as well.

The injection of compressed air into oil-bearing strata (air drive) as a technique of secondary recovery was begun before World War I and continued into the 1930's and 40's (23). Although this method is not used as much now as in the past, some interest in the method has been renewed in recent years (24). This section of the report emphasizes data from air injection as an air-drive mechanism of petroleum recovery, but some consideration is given to data from air injection as a source of oxygen in the in situ combination process of oil recovery.

In addition to problems addressed in other sections of this report (e.g., bacterial growth, explosion hazards, and environmental pollution), there is concern that the circulation of air through oil-suaked beds will oxidize crude 
oil, remove lighter hydrocarbons, and leave behind a heavy viscous mixture that will clog reservoir pores and reduce permeability. The oxidation of hydrocarbons could also raise the carbon dioxide content and ultimately the acidity of the air-reservoir and well systems and thus aggrevate problems, such as corrosion (25) or clay destabilization, discussed elsewhere in this report. Large quantities of carbon dioxide passing through the well/ turbine system might alter the compressive and thermal properties of the air mixture. Air injected into an oilbeariny stratum might by-pass tight oil-soaked zones and follow paths not anticipated in the design analysis of air-reservoir geometry. In extreme cases design reservoir volume assumptions could be invalidated.

\section{A.3.2.2 Summary of Literature}

The best summary of compressed air injection into petroleum reservoirs among the articles canvassed is the one by Dickey and Bossler (2.3). Extensive secondary recovery operdiuns were carried out in the Venango field, Ponnoylvania, using the Smith-Dunn air injection process. There the producing sands are Devonian in age and occur in a 300-foot thick zone of irregular lenticular bodies. The sands include numerous shale streaks. Permeability is highly variable ranging from 0 to 2000 millidarcies. The sands are 800 to 900 feet below ground surface. Air was introduced from special wells at pressures of 50 to 400 psi. There was a break-down (threshold) pressure below which air would not 
enter the formation. Problems of air flow through porous media are more complicated than flow problems of noncomprcsible fluids. Injected air tends to seek out the more permeable streaks and by-pass petroleum and other liquids in the tighter zones. Well patterns should allow for. locations of impermeable streaks. Dickey and Bossler found that the air flow through the oil-bearing sands oxidized portions of the crude petroleum resulting in pore clogging by the heavier compounds formed. Constant passage of air removed the lighter hydrocarbons leaving a more viscous oil behind. Another significant effect of air flow was the creation of explosive mixtures.

Flood (26) reported on air repressuring in the colmarPlymouth field of Illinois. Air was used because natural gas was not available. The field is located southwest of Macomb, Illinois. The producing formation. is the Hoing sand, of Devonian age, occurring as lenses above the Maquoketa Shale. The sand is about 400 feet deep and 10 to 12 feet thick in the test area. Air was injected at a pressure of about 50 psi. Some by-passing problems were encountered but were corrected by raising fluid level in wells.

Additional information on air repressuring in Illinois fields was provided by Bell and Squires (27) who noted that most attempts to repressure limestone were unsuccessful. 
In Ohio oil fields undergoing air repressuring, by-passing by air has been a major problem (28). In examples cited, the producing horizon was the clinton sand of Silurian age. The lenticular sand bodies lend themselves well to repressuring, but great variations in horizontal permeability were a disadvantage. Pressures used were about 50 to 90 psi.

Ryder (29) emphasized the importance of monitoring the carbon dioxide content of the produced gases as a measure of oxidation of the crude oil and of the thickening of oil left behind. In extreme cases, resulting high viscosities may force the abandonment of using air for pressuring. Bypassing and preferential air-flow paths are also important in analysis of air drive.

With increasing scarcity of natural gas there has been renewed interest in air repressuring. Crawford at Texas A\&M University experimented with oil recovery pressures of 4000 to $6000 \mathrm{psi}$ in a linear laboratory sand pack (24). In further work at Texas A\&M, Rusing et al. (30) suggested that, when air is injected into a warm oil reservoir, oxygen should react with the petroleum to yield carbon dioxide and nitrogen. The carbon dioxide would dissolve in the oil and connate water; the nitrogen would provide an inert gas drive. In laboratory experiments the authors used nitrogen at 6000 to 8000 psi on a glassbased sand, and $43^{\circ} \mathrm{API}$ at $250^{\circ} \mathrm{F}$. 
Some aspects of air injection for in situ combustion may be of interest in connection with CAES. At Brea-olinda, California, Showalter and McLean (31) reported that "occurrences that cause turbulence in the air supply such as compressor shut downs or adjustments of injection rate seem to cause surges of plugging." The importance of clean injection wells cannot be overemphasized.

Experiments in air and steam injection were carried out at the Parker field near Casey, Illinois, in Pennsylvanian sand (32). Mixtures from $100 \%$ air to steam-nitrogencarbon dioxide and no air were injected at slightly above overburden pressure and at temperatures of $800^{\circ} \mathrm{F}$. Carbon dioxide content of produced gas is a measure of degree of oxidation.

Reporting on field experience with injected air, Heim (33) discusses field investigations in the Siggins field in Illinois during which air was injected alternately with chemical foam. The foam blocked off high permeability "thief" streaks. Air was injected at 430 psig.

A final note, Watkins (25) referred to $\mathrm{CO}_{2}$ as a corrosive gas.

\section{A.3.2.3 Conclusions and Recommendations}

The major conclusion and recommendation of significance to CAES that can be drawn from experience with air-drive techniques of petroleum recovery is that petroleum-bearing 
aquifers have significant potential disadvantages not found in non-petroleum-bearing aquifers and should therefore be avoided for CAES use except in cases where some overriding compensating benefit can be demonstrated.

These potential disadvantages include anticipated problems of permeability losses related to oxidation of petroleum and/or removal of lighter hydrocarbon fractions, which are borne out by actual case histories. By-passing of air through "thief" streaks has likewise been observer, Oxidation of crude oil clearly leads to an increase of carbon dioxide, and carbon dioxide is referred to as a corrosive gas $(\underline{25})$.

Field injection pressures in the examples cited were consistently below those that would be employed in CAES, whereas pressures (and temperatures) cited in the laboratory tests were far ahove those that would be used in CAES. Presumably these discrepancies would not seriously invalidate general conclusions drawn from field data. For the most part geologic conditions in oil fields where airdrive techniques were employed most closely approximate those of the Pennsylvanian and Mississippian CAES prospects in the Illinois Basin.

The correlation of plugging with occurrences that cause turbulence in the air supply for in situ combustion (31) may have application to non-petroliferous and petroliferous 
aquifers. The use of foam to seal off zones of high permeability (33) may also be useful in certain types of nonpetroliferous aquifers. Except for explosion hazards, no specific reference to topics addressed elsewhere in this report (e.g., clay destabilization) was found in the literature on air-drive petroleum recovery.

\section{A.3.2.4 List of References Examined}

Baxton and Pollock (34), Bell and Squires (27), Dickey

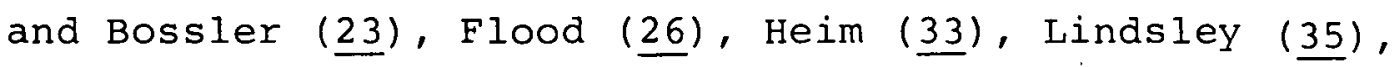
Offshore (24), Rushing et al. (푸), Ryder (29), Schaefer (28), Showalter and Mclean (1) , stone and Crump (36), Torrev (37), Walter (32), and Vatkins (25).

\section{A.3.3 Clay Mineral Destabilization and its Fffects on} Reservoir Rocks and Caprocks

\section{A.3.3.1 Definition of Potential Problems}

The instability of clay minerals in environments of changing moisture content, temperature, or water chemistry is well known to geologists, soil engineers, and others dealing with clay minerals. In the context of compressed air aquifer storage, the injection of warm dry air into the reservoir rock with the concommitant expulsion of formation (connate) waters could lead to dehydration of certain types of clay minerals. Dust-size particles thus 
liberated could find their way into withdrawal wells and from there into generator units where they could cause excessive wear to moving parts and potential contamination of the atmosphere. The dehydration of clay mineral constituents of shale caprocks could lead to cracking and deterioration of the reservoir seal in cases where the shale is in direct contact with the reservoir rock.

Another point of concern is that intergranular clay minerals stable in the presence of mineralized (formation) waters will swell and/or disperse and thus close off pore space when brought into contact with fresh water. Fresh water could be introduced into the aquifer by condensation of warm air some distance away from injection wells.

\section{A.3.3.2 Summary of Literature}

Among the references examined, Grim (38) yielded the most information on dehydration and rehydration of Glay minerals. Kaolinites show virtually no dehydration effects below $400^{\circ} \mathrm{C}$, a figure far in excess of proposed working air temperatures for CAES. Chlorite is likewise insensitive below about $500^{\circ} \mathrm{C}$.

Illite shows considerable water loss at temperatures below $100^{\circ} \mathrm{C}$ and gradual loss between $100^{\circ} \mathrm{C}$ and $350^{\circ} \mathrm{C}$. After heating from $600^{\circ} \mathrm{C}$ to $800^{\circ} \mathrm{C}$ there is a gradual gain in moisture on cooling (rehydration). 
Smectite (montmorillonite) undergoes considerable dehydration between $100^{\circ} \mathrm{C}$ and $200^{\circ} \mathrm{C}$. Above $400^{\circ} \mathrm{C}$ most phase changes occur in interlayered phases. No data for temperatures below $100^{\circ} \mathrm{C}$ are given. Smectite regains water and expands at low temperatures. The lithium variety loses the property of expansion when heated to $125^{\circ} \mathrm{C}$; the hydrogen and calcium varieties between $600^{\circ} \mathrm{C}$ and $800^{\circ} \mathrm{C}$.

Vermiculite suffers large water losses when heated to temperatures below $100^{\circ} \mathrm{C}$, then gradual losses to $850^{\circ} \mathrm{C}$. water is regained almost instantaneously at room temperature:

Other information on dehydration may have been provided by laboratory ventilation (air injection) experiments on potential sandstone reservoir rocks (39, $\underline{40})$. Apparently there is no change in porosity or permeability as a result of ventilation. However, laboratory temperatures and pressures did not completely simulate anticipated field conditions of CAES operations. Other related information is in Clark et al. (41) and subsection A.3.2.2.

Expansion of clays and loss of permeability can be a major problem in water flooding for enhanced recovery of petroleum according to many authors $(\mathrm{e} . \mathrm{g},, \underline{42}, \underline{43})$. Sodium bentonites, for example, may swell to 20 times original. volume on contact with fresh water $(\underline{44})$. Even a small amount of clay minerals in an otherwise "clean" sand can cause serious loss of permeability. 
Different clays react differently to injected fluids (43). In Gulf Coast sands containing kaolinite, there is a migration of fine particles (see also (44). Smectite (bentonite) can be very sensitive to fresh water, tho nct reaction of illite is to increase pore tortuosity, chlorites are very acid-sensitive. Wellcrystalized illite and chlorite in "dirty" Chester Series sandstones of the Illinois Basin, however, are relatively insensitive ( $\underline{45}$ ). Degraded clays in "clean" Cliester sandstones are expandable. Clay minerals in shales of the Chester Series, mostly illite and chlorite, are stable.

The special distribution of clay minerals in the reservoir rock texture is a factor in potential permeability losses. Clay minerals can occur as discrete detrital grains or as coatings on sand grains (i.e., pores are lined with clay). The first case is relatively unimportant to permeability reduction. In the second case, even a very small percentage of reactive clay minerals can cause a very serious loss in permeability $(\underline{45}, \underline{46})$.

On another point, slobod and Beiswanger (47) report experiments on test cores of Berea sandstone, known to contain water-sensitive clays, in which addition of small amounts of polymers controlled clay swelling. 


\section{A.3.3.3 Conclusions and Recommendations}

The potential for problems resulting from destabilization of clay minerals is real enough to merit careful consideration and planning of preventive and remedial measures at all proposed CAES sites. The precise mineralogical variety of clay minerals present in a rock may be a more important control of swelling or deterioration potential than is the total amount of clay minerals. In the Chester Series (Mississippian) of the Illinois Basin, illite/chloritebearing shales and "dirty" sandstones are less susceptible to swelling from water-flooding and presumably from water of condensation than are "clean" sandstones containing degraded clays. The extent to which this generalization may apply to rocks of other ages is unknown.

The distribution of clay minerals within a reservoir rock texture is potentially important. Rocks should be examined petrographically in thin sections, by $x$-rays, and with core permeability tests. The injection of small amounts of polymers may be a way to control clay swelling.

\section{A.3.3.4 List of References Examined}

Bernard ( $\underline{4}, \underline{48})$, Buckley and Leverett $(\underline{49})$, Byars and Gallop ( $\underline{50})$, Calhoun (42), Clark et al. (1), Davies and

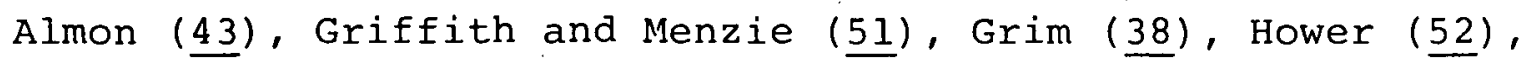

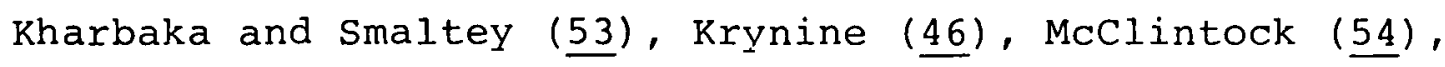

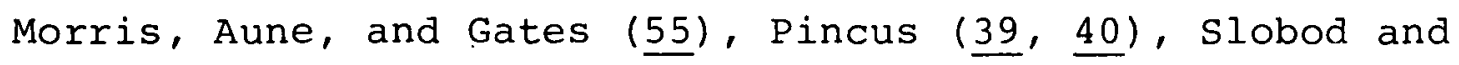

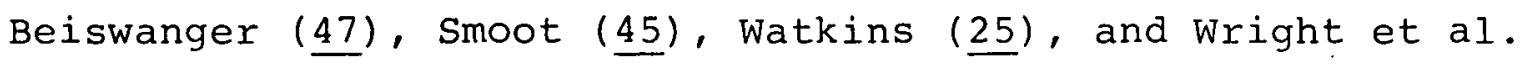
$\underline{(56)}$ 


\section{A.3.4 Possible Mechanical Failures in Reservoir Rocks and Caprocks}

\section{A.3.4.1 Definition of Potential Problems}

A unique feature of underground CAES, as compared for example to underground yas storage, is the diurnal cycle of pressure changes during normal operations. A question to be answered is whether cyclic pressure changes under elevated temperatures eventually cause fatigue damage to reservoir rock or caprock. Another consideration is the long-t.prm effecte of clevated lemperatures on reservoir and caprocks.

\section{A.3.4.2 Summary of Literature}

The literature canvass found very little that was applicable to conditions under which a CAES plant would be expected to operate.

Pincus (39, 40 ) has reported on an ongoing laboratory study of cyclir ventilation (i.e., air-injection) of st. Peter sandstone, Berea Sandstone, Salem Limestone, and other formations, at elevated temperatures and pressures. So far there has been little evidence of systematic changes in significant rock properties as a result of ventilation. Laboratory conditions, however, have not yet fully simulated expected operating conditions of CAES plants.

In other laboratory experiments ( 
Berea, St. Peter, and Bandera sandstones heated to $400^{\circ} \mathrm{C}$ to $800^{\circ} \mathrm{C}$ under atmospheric and simulated petroleum reservoir pressures showed evidence of serious mechanical disruptions and a 50\% increase in permeability. Cyclic pressure changes were not reported as part of the experiment.

A sampling of literature on in situ combusion techniques of secondary petroleum recovery was canvassed for insights into stability of reservoir or caprocks at elevated temperatures. Clark et al. (4l) reported on an in situ combustion test in Crawford County, Illinois. The Robinson sand was burned at temperatures of $1200^{\circ} \mathrm{F}$ to $1300^{\circ} \mathrm{F}$. Aside from color changes related to the oxidation of iron minerals, the sand appeared petrographically unchanged except for some increase in permeability to air.

\section{A.3.4.3 Conclusions and Recommendations}

The report of clark et al. (41) described rock subjected to temperatures as high as $1300^{\circ} \mathrm{F}$ (far in excess of any planned for CAES) that showed little change. Based on this experience, it would appear that mechanical deterioration of reservoir rocks by reason of elevated temperatures is unlikely.

On the basis of the literature examined, it is not possible to say whether the cyclic pressure changes and temperatures of normal CAES plant operation would result in mechanical damage to reservoir rocks or caprocks. Quite possibly, reservoir rocks are not affected by such changes. 
Further Iiterature canvasses are not expected to yield much data of significance.

\section{A.3.4.4 List of References Examined}

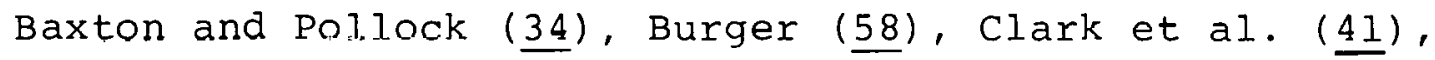
Pincus ( $\underline{39}, \underline{40})$, Showalteer and Mclean (31), Somcrton et al.

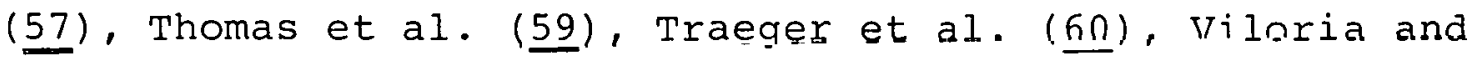

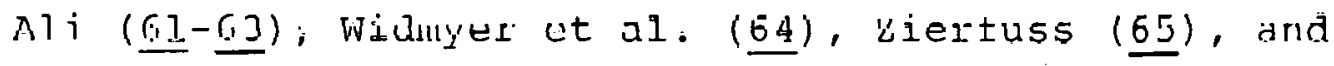
Zierfuss and Van der Vliet $(\underline{66})$.

A.3.5 Effccts of Oxidation of Iron-Bearing Minera 1 s and of steel

A.3.5.1 Definition of Potential Problems Iron-bearing minerals, particularly pyritc, are commonly present in small amounts in many potential reservoir units and caprocks. For the purposes of CAES investigations, of greatest interest are the potentially harmful effects of the nxidation of pyrite (iron sulfide) to sulfates and sulfate ions. These harmful effects could include rorrosion of well casing by acid water, reduction of reservoirrock permeability by reprecipitation of sulfate minerals, destabilization of clay minerals by changes in water chemistry (see Section A.3.3), generation of swelling pressures, and deterioration in shale caprocks.

The oxidizing environment of compressed air storage also raises the possibility of steel corrosion in well casings if any moisture is present. It is of interest to know to 
what extent this type of corrusion may exist under CAEs field conditions.

\section{A.3.5.2 Summary of Literature}

The literature canvassed yielded useful information on three points of interest: gypsum precipitation, heaving shales, and steel oxidation.

In the oil fields of Bradford, Pennsylvania, precipitated gypsum (calcium sulfate) clogged wells and lines used in waterflooding (67). The possibility of oxidized pyrite as a source of sulfate ions was considered but rejected in favor of gypsum dissolved from the reservoir rock and later reprecipated.

Heaving in shales from the Pennsylvanian-age deposits of Kansas City was ascribed to the oxidation of pyrite followed by conversion to gypsum (68).

Oxidation is associated with the drying of shales exposed to air in underground caverns. Both Byars and Gallop (50) and Nelson ( $\underline{69}$ ) report that oxygen-rich waters cause significant corrosion of steel.

\section{A.3.5.3 Conclusions and Recommendations}

Sufficient information was gathered for the consideration of two points. Yuster's (67) work suggests that sulfate ions from pyrite oxidized by contact with injected air could combine with calcium ions in formation waters to deposit gypsum in pore spaces of reservoir rock with 
consequent loss of permeability. The exact way this would happen cannot be predicted in advance, but there could be enough water present in pore spaces to permit ion transfer even long after the start of air injection. Yuster (67), in discussing the Bradford field, did not think it probable that sulfate ions came from oxidized pyrite, but this does not rule out the possibility of it happening elsewhere. In some Pennsylvanian sandstone reservoirs interbedded coal streaks could be an important source of pyrite.

In cases where highly pyritiferous shale caprocks are in direct contact with reservoir beds and are injected with dry air, the oxidation of pyrite with resulting formation of gypsum may impose expansive stresses on the shale. The magnitude and importance of these stresses should be considered in reservoir evaluation.

No literature pertaining directly to sorrosion of steel. casing or destabilization of clay minerals by oxidized pyrite was seen but a further search could be productive. Literature examined did indicate that well casings will be subject to oxidation if any moisture is present, unless preventive action is taken.

\section{A.3.5.4 List of References Examined}

Allred ( $\underline{70})$, Byars and Gallop (미), Coveney and Parizek

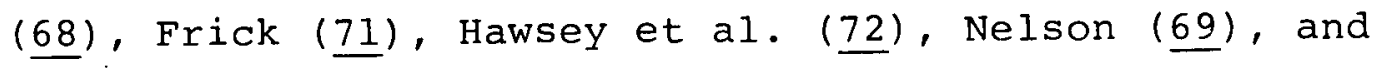
Yuster $(\underline{67})$. 
CAES-T2

\section{A.3.6 Problems of Bacterium and Other Microorganism Prolifieration}

\section{A.3.6.1 Definition of Potential Problems}

Unchecked proliferation of bacteria resulting in the loss of reservoir rock permeability and/or the corrosion of casing and other lines has been a major concern in waterflooding oil-recovery and underground natural gas storage projects.

With reference to CAES, bacteria or other microorganisms introduced into the well-reservoir system might spread into connate waters or waters of condensation, causing reservoir plugging and generation of acid products capable of corrosion. An assessment of the probability of such occurrences and of preventive remedial measures that could be taken is of considerable importance in. CAES planning. Aside from effects on the reservoir itself, another possible result of the introduction of microorganisms into aquifer systems is the contamination of nearby potable water resources. This subject is addressed in section A. 3.8 .

\section{A.3.6.2 Summary of Literature}

Allred (70) summarizes the potential problems caused by microorganisms in waterflooding for enhanced oil recovery. The following are the three most important types of problem-causing microorganisms: sulfate-reducing bacteria, iron bacteria, and capsule (slime-forming) bacteria. 
Sulfate-reducing bacteria (genus Desulfovibrio) are very tough and resistant to bacteriacides. The bacteria are anaerobic but cannot be killed by aeration. They do not need organic matter to grow. The bacteria derive hydrogen from yalvanic corrosion of steel pipe alla use 1 t to form hydrogen sulfide by reduction of sulfates. Hydrogen sulfide then combines with ferrous ions in water to form insoluble ferrous sulfide, which clogs rock pores and plugs piping.

Iron bacteria accumulate ferric hydroxide around wells. They grow besl at low temperatures and can exist in waters containing between 0.9 to 9.0 ppm oxygen. No organic matter is necessary for thej.r grow.th. Iron bacteria cause much trouble by blocking lines and casing with gelatinous; slimy masses of iron hydroxide.

Capsule bacteria form slime masses on pipe, but because they need organic matter to grow, they are not a major problem in waterflooding.

Hawsey et al. (2) point out that sulfate-reducing and iron bacteria can cause serious corrosion problems. Sulfate bacteria are found in many different kinds of waters and as troublesome contaminants in underground gas storage facilities of the aquifer type. Iron bacteria of the genera Gallionella and Sphaerotilus occur in fresh waters.

Any sign of hydrogen sulfide, sour oil, black water, or iron sulfide in the effluent or in the wells or pipes 
indicates bacterial contamination. Surficants applied through water wells, combined with hydrofracturing can help eliminate bacteria. Surficant can be administered in liquid form.

Crowe (73) emphasizes treatment of bacterial residues from water-injection wells. Pores can be clogged by organic matter or by ferrous sulfide, ferric sulfide, or ferric hydroxide. Corrosion of steel can be inhibited by application of hypochlorite, to oxidize organic deposits, followed by acidizing to dissolve inorganic residues.

\section{A.3.6.3 Conclusions and Recommendations}

In the environment of compressed air storage, sulfatereducing bacteria and possibly molds appear to be the organisms most likely to exist. Since sulfate-reducing bacteria can proliferate in the oxygenated waters of a waterflood drive, their existence is probable in aquifer waters or waters that condense in the reservoir rock some distance from the well bore. In the worst possible case, sulfate-reducing bacteria introduced into the air reservoir through the well bore would proliferate in the existing moist environment of the aquifer. By the time all moisture was expelled (and this process might never be complete), serious plugging with sulfide compounds may have occurred. As water is expelled, these compounds may be oxidized to sulfates with all the attendant problems addressed in Section A.3.5. Under some conditions sulfate-reducing bacteria introduced by CAES could contaminate potalle aquifers. 
Some consideration should be given during plant design to preventing bacterial contamination.

\section{A.3.6.4 List of References Examined}

Allred ( $\underline{70})$, Bastin and Greer (4), Crowe (3) , Hawsey et al. ( $(\underline{72})$, Lada ( $\underline{75})$, and Raleigh and Flock (ㄷ).

\section{A.3.7 Thermal Stresses on Well Casings}

A.3.7.1 Definition of Potential Problems

Although thermal stresses on well casings are more a mechanical or petroleum engineering consideration than a geological one, geology is necessary to estimate the formation temperatures likely to be encountered in CAES reservoirs. Of interest to the CAES system is whether well casings might fail under thermal stresses generated at the air-injection temperatures, assumed to be a maximum of. $150^{\circ} \mathrm{F}$.

\section{A.3.7.2 Summary of Literature}

A Natural Research Council study (77) reports that conventional drilling techniques and equipment (including casing) can be used up to temperatures of about $350^{\circ} \mathrm{F}$ without special difficulty and up to $500^{\circ} \mathrm{F}$ with greatly increased wear and other undesirable effects. Rubber components in seals and packers and downhole motors are limited to between $300^{\circ} \mathrm{F}$ and $350^{\circ} \mathrm{F}$ and conventional drilling muds to about $300^{\circ} \mathrm{F}$. 
Laboratory investigations of thermal expansion of cemented casing were performed by smith (8). Extrapolating his results to field conditions in oil wells, Smith (78) concluded that casing cemented with neat cement can be heated to about $430^{\circ} \mathrm{F}$ without adverse effects. With Lummile cement, casing elongation is negligible.

Dyart and Respese (79) found that even under extreme conditions at great depth, casing free of cement is in no danger of parting. With cementing, vertical pipe movement is restrained. Radial separation from cement might occur, but cracks so formed are very small and inaccessible to fluids because of compression.

\section{A.3.7.3 Sonclusions and Recommendations}

There should be no failure or damage to well casings because of thermal stresses, assuming injection/withdrawal wells are drilled with equipment and materials approximating those used in the petroleum industry. Normal oil wells can be drilled at temperatures up to $300^{\circ} \mathrm{F}$ to $350^{\circ} \mathrm{F}$ (at the lowest estimate) without encountering special problems. Assuming a near-surface temperature of $60^{\circ} \mathrm{F}$ and a geothermal gradient of $1.25^{\circ} \mathrm{F}$ per 100 feet $(\underline{78})$, even a 4000-foot deep well should not experience temperatures in excess of $110^{\circ} \mathrm{F}$. Maximum operating temperatures of CAES should be no greater than $150^{\circ} \mathrm{F}$. 


\section{A.3.7.4 List of References Examined}

Davis and Dewest ( $\underline{80})$, Dyart and Respress (79), National Research Council (77), and Smith (으).

\section{A.3.8 Environmental Concerns and Hazards}

\section{A.3.8.1 Definition of Potential Problems}

Under certain circumstances, the circulation of air through reservoir syetcmo can iniliate environmental disturbances above and below ground. The nature, probability of occurrence, and preventive measures that might be applied to such disturbanccs will have lo be addressed in applications to public authorities for permission to develop CAES sites.

The most dramatic of the possible environmental hazards is atmospheric emission and/or explosion of hydrocarbons derived from depleted oil fields used for CAES. Additional impact on air quality, both at hydrocarbon and non-hydrocarbon bearing CAES sites, could result from emissions nf noxious gases (such as $\mathrm{CO}_{2}$ or $\mathrm{H}_{2} \mathrm{~S}$ ) and emission of solid particles originating in the air reservoir rock (see sections A.3.2 and A.3.3 for details).

With respect to underground water supplies, potential undesirable side-effects of air injection include thermal, chemical, and biological contamination of the air-storage aquifer, and, if there is leakage through the caprock, of other aquifers as well. Disturbance of local flow systems and well yields are another possible effect of CAES aquifer storage. 


\section{A.3.8.2 Summary of Literature}

of the literature canvassed, the best overal1 summary of potential environmental problems is the article by Stottlemyre and Loscutoff (81). The authors confine themselves to a listing and brief explanation of possible environmental concerns of CAES and to suggestions for future research programs. The environmental concerns listed are essentially the same as those mentioned in subsection A.3.8.1, which is based to a considerable degree on the stottlemyre and Luscutoff (81) paper. Many of the concerns are suggested by experiences of allied technologies such as enhanced oil recovery.

Several of the papers examined point out the danger of explosions when air is used to repressure oil fields. Ryder (29) states that any air-gas mixture in the casing head is potentially explosive if the quantity of air is more than $80 \%$ to $20 \%$ gas and that it is best to keep the air content below 60\%. Dickey and Bossler (23) refer to explosion problems in the Venango Field, Pennsylvania. On the other hand, Russian workers have reported no adverse effects from injection of natural gas into aquifers previously tested with injected air (82). 
of special interest to CAES is Watkins (25) report of fire hazards from methane released from non-petroleum bearing aquifers (Arbuckle series of southeastern Kansas).

\section{A.3.8.3 ronglusions and Recommendations}

The possibility of explosion hazards and air pollution by emission of noxious gases into the atmosphere will require control medsures at any CAES site where use of a depleted petroleum reservoir is contemplated. Further details on $\mathrm{CO}_{2}$ generation are given in section A.3.2.

As pointed out in Section A.3.6, since bacteria introduced underground by waterflooding are known to contaminate oil reservoirs, bacteria introduced by air injection could contaminate air reservoirs and through them (directly or indirectly) potable-water aquifers beyond the air "bubble." This matter should be studied and necessary preventive or remedial measures planned. A brief discussion of bacterial control is presented, in section A.3.6.

\section{A.3.8.4 List of References Examined}

Dickey and Bossler (23), Economic Commission for Europe (82), Jones (83), Lindsly (ㅌ5), Ryder (29), Stottlemyre and Loscutoff (1ㅗ), and Watkins (25). 


\section{A.3.9 Miscellaneous}

\section{A.3.9.1 Introduction}

In the course of canvassing literature on the previously discussed topics, references were found un ullier miscellaneous subjects of possible interest to CAES. A brief summary on noteworthy points is presented in the following subsection.

\section{A.3.9.2 Summary of Literature and Commentary}

Holder et al. ( $(84)$ reported that solid lydsales of methanc and other gases form at temperatures of about $55^{\circ} \mathrm{F}$ to $65^{\circ} \mathrm{F}$ at depths of about 3000 to 4000 feet. Hydrate compounds are of possible interest as sealants at spill points of underground natural gas reservoirs. Bond (8), however noted that low temperatures would be needed to form the hydrates in the first place. He suggests that this problem could be mitigated by using $\mathrm{H}_{2} \mathrm{~S}$ hydrates instead of methane hydrates.

With respect to CAES, hydrates as reservoir seals would seem to be of more theoretical than practical interest. Naturally occurring hydrates in oil/gas reservoirs would presumably be converted to gaseous methane when heated by warm injected air. The possibility of explosions would then be an additional factor to consider when evaluating petroleum reservoirs for CAES use.

Another point of possible CAES interest is Bond's ( 1 ) remark that the injection of $\mathrm{CO}_{2}$ or carbonated water might increase the permeability of limestone, and possibly sandstone, reservoirs because of its ability to dissolve carbonates. 
Addressing another topic, Overby and Rough (85) presented. results of a study of vertical jointing in the salamanca Sandstone of the Bradford field of Pennsylvania and Alleylieny field of New York. Strike directions on the surface can be used to predict the trends of induced fracturing in the Third Bradford Sand. Knowledge of potential fracture patterns in reservoir and caprocks could be useful in cAEs site evaluation.

Possible application of geothermal well technology to CAES were briefly canvassed. Takahashi et al. (6) noted that petroleum and water-well drilling hardware could be adapted to geothermal service. From this it would follow that this type of hardware could also be used for CAES. Wehlage's (87) book on geothermal engineering is a good overall introduction to the subject but contains little of relevance to CAES.

In the hope of uncovering information of value in the analysis of reservoir-rock permeability, several references were reviewed. Neither Odel (8), Walls (9), nor Rernik et al. (90) appeared to be of significant relevance to CAES studies.

of more interest was Bernard's wốk (48) on the effects of reactions between interstitial and injected waters on the permeability of reservoir rocks. Testing Berea Sandstone cores with a variety of chemical solutions, Bernard (48) reported no reduction of permeability by reaction between the solutions, although this result does not necessarily apply to possible effects on solids such as clay minerals. 
A.3.9.3 List of References Examined

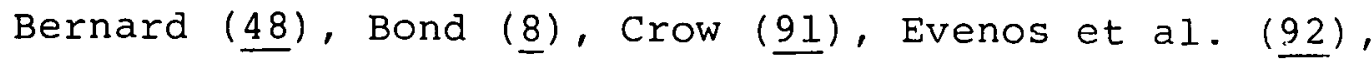

Holder et al. (4), Katz (93), Kuuskraa et al. (944),

Linville (ㅁ), McCarthy (96), Odel (88), Overby and Rough

(5) $)$ Reznik et al. (90), Rudd (97), Slobod (98), Takahaski

et al. ( $\underline{86})$, Walls ( 199$)$, and Wehlage (87) .

\section{R.EFERFNCES}

1. D. L. Ayers and R. E. Strong. "Compressed Air Storage Another Answer to the Peaking Problem." Power Engineering, Vol. 79, No. 8 (August), 1975, pp. 36-39.

2. D. R. Bervig and R. W. Pinker. "An Assessment of Compressed Air Energy Storage." In Proceedings of the 1978 Compressed Air Energy Symposium, pp. 127-128. Pacific Grove, California: Department of Energy, 1979. CONF-780599.

3. J. Fleury. "Energy Transfer by Compressed Air Storage." Revue generale de thermique, Vol. 14, No. 157 (Jan.), 1975, pp. 17-25. In French.

4. H. Harboe. "The Use of Compressed Air for Energy Storage." Amer. Chem. Soc. Div. Fuel Chem. Preprint, Vol. 19, No. 4, 1974, pp. 151-161.

5. D. L. Katz and E. R. Lady. Compressed Air Storage. Ann Arbor, Michigan: Ulrich's Books, Inc., 1976.

6. F. C. Rogers and A. E. Allen. "Energy Storage Underground." Anaheim, California: Power Engineering Society Summer Meeting and Energy Resources Conference, July 1974 .

7. General Electric Company. "Economic and Technical Feasibility study of Compressed Air storage." Schenectady, New York: U.S. Energy Research and Development Administration, 1976. No. E(11-1)-2559. ERDA 76-76.

8. D. C. Bond. "Underground Storage of Natural Gas." Illinois Petroleum, No. 101. Urbana, Illinois: Illinois state Geological Survey, 1975. 
9. T. C. Buschbach and D. C. Bond. "Underground Storage of Natural Gas in Illinois." Illinois Petroleum, No. 101. Urbana, Illinois: Il Iinois state Geological. Survey, 1974 .

10. M. J. Hulsen et al. "Feasibility of CAES in California." In Proceedings of the 1978 Compressed Air Energy Symposium, pp. 179-212. Pacific Grove, California: Department of Energy, 1979. CONF-780599.

11. D. A. Howells. "Geotechnical Problems of Cavern Storage." The Consulting Engineer, Vol. 40, No. 11, 1976, pp. 39-41.

12. G. T. Kartsounes. "Evaluation of Turbille Systems for Compressed Air Energy storage Plants." Argonne, Illinois: Argonne National Laboratory, 1976. ANL/ES-59.

13. C. S. Kim and G. T. Kartsounes. "A Parametric study of Turbine Systems for Compressed Air Energy Storage Flants." Argonne, Illinois: Argonne National Laboratory, 1978. ANL/ES-64.

14. R. S. Korsmcyer. "Underground Air Storage and Electrical Energy Pruduction." Oak Ridge, Tennessee: Oak Ridge National Laboratory, 1972. ORNL-NSF-EPIl.

15. W. Park et al. Benefit/Cost Analysis of Accelerating R\&D Activities Directed at Near-Term Electric Utility Applications, Vol. 1: "Methodology, Analysis, and Results," Vol. 2: "Program Descriptions." Mitre Corporation, 1978. ERDA MTR-7447.

16. G. C. Smith and L. E. Wiles. "Analysis of Underground Porols Reservoirs for Compressed Alr Fnergy Storagc." In Proceedings of the 1978 Compressed Air Energy Symposium, pp. 327-368. Pacific Grove, California: Department of Energy, 1979. CONF-780599.

17. W. H. Day, R. K. Alff, and F. M. Jarvis. "Pumped Air Storage for Electric Power Generation." Anaheim, California: Power Engineering Society Summer Meeting and Energy Resources Conference, July 1974. Paper 74CHO913-4-PWR.

18. Engineering News-Record. "Compressor Kinks Unraveled at German Air Energy Plant," Nov. 30, 1978, p. 18.

19. A. J. Giramonti. "Preliminary Feasibility Evaluation." United Technologies Research Center, 1976. 
20. E. R. Lady and D. L. Katz. "Underground Compressed Air Storage for Electric Utility Load Levelling." Journ. Petrol. Technol., November 1978, pp. 1656-1660.

21. J.A. Stottlemyre et al. "Stability Criteria and Compressed Air Energy Storage in a Porous Rock Reservoir." In Proceedings of the 1978 Compressed Air Energy Symposium, Pp. 213-242. Pacific Grove, California: Department of Energy, 1979. CONF-780599.

22. J. Despois and E. F. Nougarède. "Thermal Aspects of Present Day Energy Problems," Recontre annuelle de la Societé Francaise de thermiciens, Grenoble, France. In French.

23. P. A. Dickey and R. B. Bossler. "Venango Fields of Pennsylvania," Producers Monthly, Vol. 5, November, 1940, pp. 9-21.

24. Offshore. "Texas Researcher Uses Air at High Fressure to Recover Oil," Vol. 16, No. 5, 1976, p. 312.

25. J. W. Watkins. "Produced Waters." In Petroleum Producers Handbook, edited by T. C. Frick, Chapt. 21, Vol. 2. New York: McGraw Hill, 1962.

26. W. H. Flood. "Air Repressuring in Colmar - Plymouth Field of Illinois," Oil and Gas Journ., July 14, 1938, p. 44-50.

27. A. H. Bell and F. Squires. "Illinois - Secondary Recovery," Producers Monthly, Vol. 6, No. 11 (Sept.), 1941, pp. 10-14.

28. J. E. Schaefer. "Ohio - Secondary Recovery," Producers Monthly, Vol. 6, No. 6 (April), 1941, pp. $11-1 \overline{5}$.

29. H. M. Ryder. "Pressuring Efficiency," Producers Monthly, Vol. 1, No. 12 (Oct.), 1937, pp.6-l1.

30. M. D. Rushing et al. "High Pressure Air Injection," Petrol. Eng., Vol. 48, No. 3, 1976, pp. 52-56.

31. W. E. Showalter and M. A. McLean. "Fireflood at Breaolinda Field, Orange County, California," Tulsa, Oklahoma: Soc. Petrol. Eng. (AIME) Symposium Improved Oil Recovery, 1974. Paper SPE-4763.

32. H. Walter. "Application of Heat for Recovery of oil: Field Test Results and Possibility of Profitable Operation," Journ. Petrol. Technol., Vol. 9, February, 1957, pp. $16-22$. 
33. L. W. Heim. "Foam Injection Test in the Siggins Field, Illinois," Journ. Petrol. Technol., Vol. 22, 1970, pp. 1499-1506.

34. T. S. Baxton and C. B. Follock. "The Sloss COFCAW Project - Further Evaluation of Performance during and after Air Injection," Tulsa, Oklahoma: Soc. Petrol. Eng. (AIME) Sympos. Improved Oil Recov., 1974, Paper SPE- 4766 .

35. B. L. Lindsly. "The Application of Compressed Air to the Elliot Pool, Nowata County, Oklahoma," U.S. Bur. Mines, 1.926, Rept. Invest. 2778.

36. I. L. Stone and J. S. Crump. "The Effect of Gas Composition on Oil Recovery," Trans. AIME, Vol. 207, 1956, pp. 105-110.

37. P. D. Torrey. "New Technioues for Improving Oil Recovery," Producers Monthiy, vol. 22, January, .2958, pp. $27-40$.

38. R. Grim. Clay Mineralogy, 2nd edition. New York: MrGraw-Hi1 1, 1968 .

39. H. J. Pincus. "Underground Compressed Air Fnergy Storage Laboratory Studies of Pressure-Temperature Cycling." Richmond, Washington: Pacific Northwest Laboratory, Battelle Memorial Institute, 1978. PLil Award B-5777/4A-K.

40. H. J. Pincus. "Fabric Analysis of Ventilated Rocks." In Proceedings of the 1978 Compressed Air Energy Symposium, pp. 279-294. Pacific Grove, California: Department of Energy, 1979. CONF-780599.

41. G. A. Clark et al. "The Fry in-situ Combustion Test Performance," Journ. Petrol. Technol., Marili, 1965. pp. 348-363.

42. J. C. Calhoun, Jr. Fundamentals of Reservoir Engineering, Norman, Oklahoma: University of oklahoma Press, 1953 .

43. D. K. Davies and W. R. Almon. "Clay Technology and Well Stimulation," (abstract). Bull. Amer. Assoc. Petrol. Geol., 1978, pp. 1756-1757.

44. G. C. Bernard. "Effect of Floodwater Salinity on Recovery of Oil from Cores containing Clays," Producers Monthly, Vol. 32, No. 6 (June), 1968, pp. 2.-5.

45. T. W. Smoot. "Clay Mineralogy as Applied to Secondary Recovery Problems," Producers Monthly, Vol. 23, June, 1959, pp. 32-36. 
46. P. D. Krynine. "Mineralogy of Water Flooding," Producers Monthly, Vol. 3, No. 2, December, 1938, pp. 10-13.

47. R. L. Slobod and F. G. Beiswanger. "Use of Polymers to Control Clay Swelling," Producers Monthly, Vol. 32, No. 8, August, 1968, pp. 21-26.

48. G. C. Bernard. "Effect of Reactions between Interstitial and Injected Waters on Permeability of Reservoir Rocks." Urbana, Illinois: Illinois state Geological Survey, 1957. Bulletin 80 .

49. Buckley and Lcverett. Mechanism of Fluid Displacement in Sands," Trans. Amer. Inst. Min. Eng., Vol. 146, 1942, pp. 107-116.

50. H. G. Byars and B. R. Gallop. "Injection + Oxygen = Corrosion and/or Well Plugging Solids," Materials Performance, Vol. 13, No. 12 (Dec.), 1974, pp. 3I-36.

51. A. F. Griffith and D. E. Menzie. "Brine and Fresh Water Permeability of a hater-sensitive sand," Producers Monthly, November, 1957, pp. 27-31.

52. W. F. Hower. "Influence of Clays on the Production of Hydro-Carbons," Soc. Petrol. Eng., AIME, February, 1974.

53. Y. K. Kharbaka and W. C. Smaltey. "Flow of Water and Solutes through Compacted Clays," Bull. Amer. Assoc. petrol. Geol., Vol. 60, 1976, pp. 973-980.

54. C. B. McClintock. "Geologic Factors of Repressuring in Pennsylvania Region," Producers Monthly, Vol. 1, October, 1937, pp. 26- 27 .

55. F. C. Morris, Q. A. Aune, and G. L. Gates. "Clays in Petroleum Reservoir Rocks: Its Effect on Permeability, with Particular Reference to Tejon-Grapevine Area, Kern County, California," U.S. Bur. Mines, 1959. Rept. Invest. 5425.

56. J. Wright et al. "Analysis of Brines from.oil Productive Formation in Oklahoma," U.S. Bur. Mines, 1957. Rept. Invest. 5226.

57. W. H. Somerton et al. "Thermal Alteration of Sandstone," Journ. Petrol. Technol., Vol. 17, 1965, pp. 589-593.

58. J. E. Burger. "Spontaneous Ignition in Oil Reservoirs," Journ. Soc. Petrol. Eng., Vol. 16, No. 2'(April), 1976, pp. 73-81. 
59. J. Thomas, Jr., et al. "Thermal Conductivity of Carbonate Rocks," Engineering Geology, Vol. 7, 1973, pp. 3-12.

60. R. K. Traeger et al. "Deep Steam Project 16, Enhanced Oil Recovery - Quarterly Report for October 1 December 31, 1977," Sandia Laboratory, 1978. SAND 78033 .

61. G. S. Viloria and F. Ali. "Thermal Propertics of Rocks and Fluids," Producere Munthly", Vol. 12, No. 7 (July) 1968 , pp. 70-74.

62. G. S. Viloria and F. Ali. "Thermal Conductivity and its Variation with Density, Temperature, and Fluid SaturaLiun," Pruducere Monthly, vol. 32, No. U (August), lycis, N. $27=\overline{30}$.

63. G. S. Viloria and F. Ali. "Measurement of Rock Thermal Conductivity," Producers Monthly, Vol. 32, No. 9 (sopt.), 1968, pp. 22*25.

64. R. H. Widmyer et al. "The Charco Redondo Thermal Recovery Pilot," Journ. Petrol. Technol., Vol. 29, 1977, pp. 1522-1532.

65. H. Zierfuss. "Heat Conductivity of Some Carbonate Rocks and Clayey Sandstones," Bull. Amer. Assoc. Petrol. Geol., Vol. 53, 1969, pp. 251-260.

66. H. Zierfuss and G. Van der Vliet. "Laboratory Measurements of Heat Conductivity of sedimentary Rocks," Bull. Amer. Assoc. Petrol. Geol., Vol. 40, 1956, pp. 2475-2488.

67. S. T. Yuster. "The Gypsum Problem in Watcr Flooding," Producers Monthly, Vol. 3, No. 6 (April), 1939, pp. 27-35.

68. R. M. Conveney and E. J. Parizek. "Deformation of Mine Floors by Sulfide Alteration," Bull. Assoc. Eng. Geol.." Vol. 14, 1977, pp. 131-156.

69. H. W. Nelson. "Corrosion Problems and Chemical Treatment," Producers Monthly, Vol. 2, No. 5 (March), 1938, pp. $10-\overline{14}$.

70. R. C. Allred. "The Role of Microorganisms," Producers

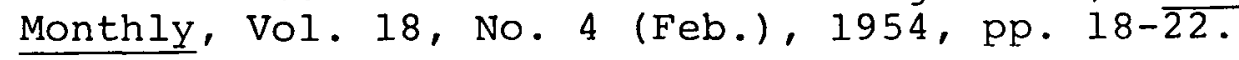

71. T. C. Frick, ed. Petroleum Production Handbook, 2 Volumes. New York: McGraw Hill, 1962. 
72. J. W. Hawsey et al. "Eliminating Bacterial Contamination in Producing and Gas-storage Wells," Producers Monthly, Vol. 20, No. 11 (Nov.), 1964, pp. 8-11.

73. C. W. Crowe. "New Treating Technique Removes Bacterial Residues from Water Injection Wells," Producers Monthly, Vol. 32, No. 8 (Aug.), 1968, pp. 2-8,

74. E. S. Bastin and F. E. Greer. "Additional Data on Sulphate - Reducing Bacteria in Soils and Waters of Illinois Oil Fields," Bull. Amer. Assoc. Petrol. Geol., Vol. 14, 1930, pp. 153-159.

75. A. Lada. "The Role of Microorganisms in Secondary oil Recovery," Producers Monthly, Vol. 23, Apri1, 1959.

76. J. T. Raleigh and D. L. Flock. "A Study of Formation Plugging with Bacteria," Journ. Petrol. Technol.,

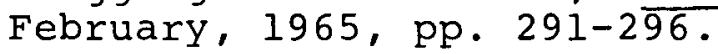

77. National Research Council. "Report Ad Hoc Committee on Technology of Drilling for Energy Resources," U.S. Dept. Commerce, Nat. Tech. Inf. Service, 1976. PB 259206 .

78. F. M. Smith. "Thermal Expansion of Cemented Casing," Producers Monthly, Vol. 31, No. 3 (March), 1967, Pp. 2-8.

79. G. R. Dyart and C. Respess. "Stresses on Casing and Cement Caused by Changing Temperatures," Producers Monthly, Vol. 32, No. 3 (March), 1968, pp. 20-23.

80. S. N. Davis and R. J. M. DeWest. Hydrology. New York: John Wiley \& Sons, 1966.

81. J. A. Stottlemyre and w. V. Loscutoff. "Environmental Concerns for Compressed Air Energy Storage in Porous Media Systems," In Proceedings of the 1978 Compressed Air Energy Symposium, pp. 667-686. Pacific Grove, California: Department of Energy, 1979. CONF-780599.

82. Economic Commission for Europe Committee on Gas. "The Theoretical and Economic Aspects of Storage of Gas in Water-Bearing Beds Situated in Horizontal or Slightly Sloping strata," Report received from the USSR:

Economic Commission Europe, Committee on Gas; Working Party on the Transmission of Gas (1st session), Gas/ WP.5/Working Paper No. 3, April 27, 1966. English (orig. Russian). 
83. G. W. Jones. "Explosion Hazards of Petroleum Vapors," Producers Monthly, Vol. 2, No. 2 (Oct.), 1938. pp. 10-17.

84. G. D. Holder et al. "Hydrate Formation in Subsurface Environments," Bull. Amer. Assoc. Petrol. Geol., Vol. 60, 1976 , pp. 981-994.

85. W. K. Overby, Jr., and R. L. Rolugh. "Surface Studies Predict Urientation of Induced Formation Fractures," Producers Monthly, vol. 32, No. 6, 1968, pp. 16-19.

86. P. K. Takahashi et al. "State of the Art of Geothermal Reservoir Engineering," Journ Power Div., Amer, Soc. Civil Enq., Vol. 101, 1.975, Mp. 171-1?6.

87. E. F. Wehlage. The Basics of Applied Geothermal Engineering. West Covina, California: Geothermal Publishing Co., 1975.

88. A. S. Odel. "Effect of Viscosity Ratio on Relative Permeability," Journ. Petrol. Technol., Vol. 216, 1959, pp. 346-353.

89. C. G. Walls. "Permeability, Pore size," Institute of Petroleum Journ., Vol. 51, 1965, pp. 195- 200 .

90. A. A. Reznik et al. "Air-Water Permeability Studies of Pittsburgh and Pocahontas Coals," Journ. Soc. Petrol. Eng., Vol. 14, No. 6, 1974, pp. 556-562.

91. C. V. Crow. "Shanghai Underground Gas Storage Field," unpublished manuscript, Illinois Power Company, undated.

92. A. I. Evenos et al. "Impermeation of Porous Media by in-situ Hydrate Formation," Soc. Petrol. Fng. (AIME), 1970. Proprint SFE-2801.

93. D. L. Katz. "Making Good Use of Observation Wells in Gas Storage." St. Louis: Amer. Gas Assoc. Transmission Conf., 1977.

94. V. A. Kuuskraa et a1. "Research and Development in Enhanced Oil Recovery." Nat. Tech. Inf. Service, December, 1976.

95. B. Linville. "Contracts and Grants for Cooperative Research on Enhancement of Recovery of Oil and Gas." Bartlesville, Oklahoma: Bartlesville Energy Research Center, 1977. 
96. D. F. McCarthy "Underground Storage Facilities for Gaseous and Liquid Hydrocarbons," Pipeline and Gas Journ., March, 1972, pp. 52-58.

97. N. Rudd. "Evaluation of Caprock for Underground Compressed Air Energy Storage." In Proceedings of the 1978 Compressed Air Energy Symposium, pp. 243-278. Pacific Grove, California: Department of Energy, 1979. CONF-780599.

98. R. L. Slobod. "Review of Methods Used to Increase Oil Recovery," Producers Monthly, February, 1958, pp. 24-31. 
THIS PAGE

\section{WAS INTENTIONALLY LEFT BLANK}


A.B

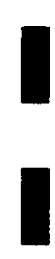


Attachment $B$

RESERVOIR DATA FOR COMPRESSED AIR STORAGE SITES

CONTEN'IS

Table

Page

B-1 Reservoir Data for Compressed Air Storage

$\mathrm{B}-1$ at the Brocton Site in Douglas and Edgar Counties, Illinois, Located in section 27 , Township 15 North, Range 14 West

$B-2$

Reservoir Data for Compressed Air Storage at the Brookville site in ogle County, Illinois, Located in section 2, Township 23 North, Range 7 East

Reservoir Data for Compressed Air Storage at the Deland site in Piatt County, Illinois, Located in section 8, Township 19 North, Rànge 5 East

Reservoir Data for Compressed Air Storage at the Fishhook Site in Pike and Adams Counties, Illinois, Located in Section 32 , Township 3 South, Range 4 west

B-5 Reservoir Data for Compressed Air Storage at the Hume Site in Edgar County, Illinois, Located in Section 24, Township 16 North, Range 14 West at the Lewis site in Sullivan County, Indiana, Iocated in section 9, Township 9 North, Range 8 West

B-7 Reservoir Data for Compressed, Air Storage at the Media Site in Henderson County; Illinois, Located in section 17, Township 9 North, Range 4 West at the Parnell site in Dewitt County, Illinois, Located in section 3, Township 20 North, Range 4 East

B-9 Reservoir Data for Compressed Air Storage at the Paxton Site in Sullivan County, Indiana, Located in Section 33, Township 7 North, Range 9 west 


\section{CONTENTS (Cont'd)}

Table

Page

B-10 Reservoir Data for Compressed Air Storaqe

$B-10$ at the Prairie Creek site in Vigo County, Indiana, Located in Sections 15 and 16 , Township 10 North, Range 10 West

B-ll Reservoir Data for Compressed Air Storage $\mathrm{B}-11$ at the Toulun A Site in Henry County, Illinois, Located in section 26, Township 14 North, Range 5 East

$\mathrm{B}-12$

Reservoir Data for Compressed Air Storage $\mathrm{B}-1.2$ at the Toulon B Site in stark County, Illinois, Located in section 11, Township 13 North, Range 5 East

B-13 Reservoir Data for Compressed Air Storage $B=13$ al Lle wadesville west Site in Posey comnty, Indiana, Located in Section 11, Township 5 Suuth, Range 13 west

$\mathrm{B}-14$

Reservnir nata for Compressed Air storáge at the Wappella East. Site in Dewitt county, Illinois, Located in Section 28, Township 21 North, Range 3 East 
TABLE B-1

RESERVOIR DATA FOR COMPRESSED AIR STORAGE AT THE

BROCTON SITE IN DOUGLAS AND EDGAK COUNTIES, ILLINOIS, LOCATED IN SECTION 27, TOWNSHIP 15 NORTH, RANGE 14 WEST

PARAMETER

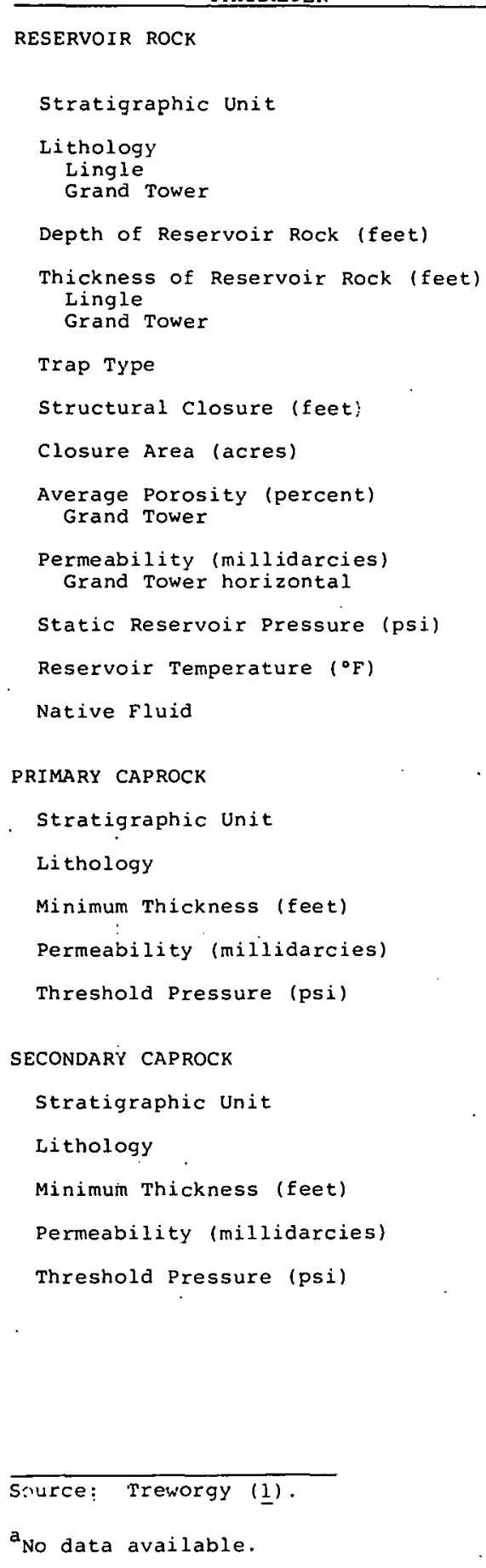

VALUF,

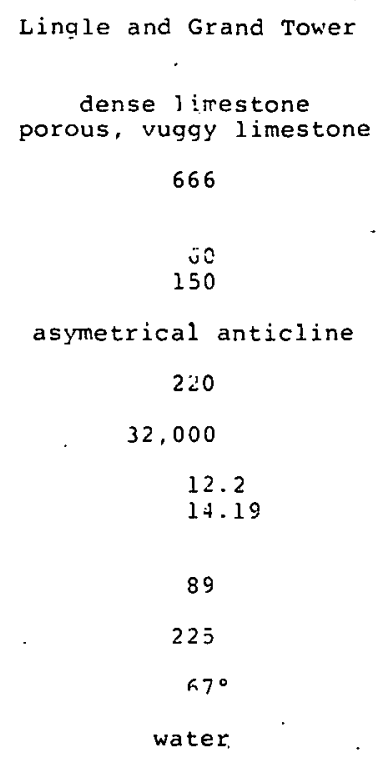


CAES-T 2

TABLE B-2

RESERVOIR DATA FOR COMPRESSED AIR STORAGE AT THE

BROOKVILLE SITE IN OGLE COUNTY, ILLINOIS,

LOCATED IN SECTION 2, TOWNSHIP 23 NORTH, RANGE 7 EAST

PARAMF,TER

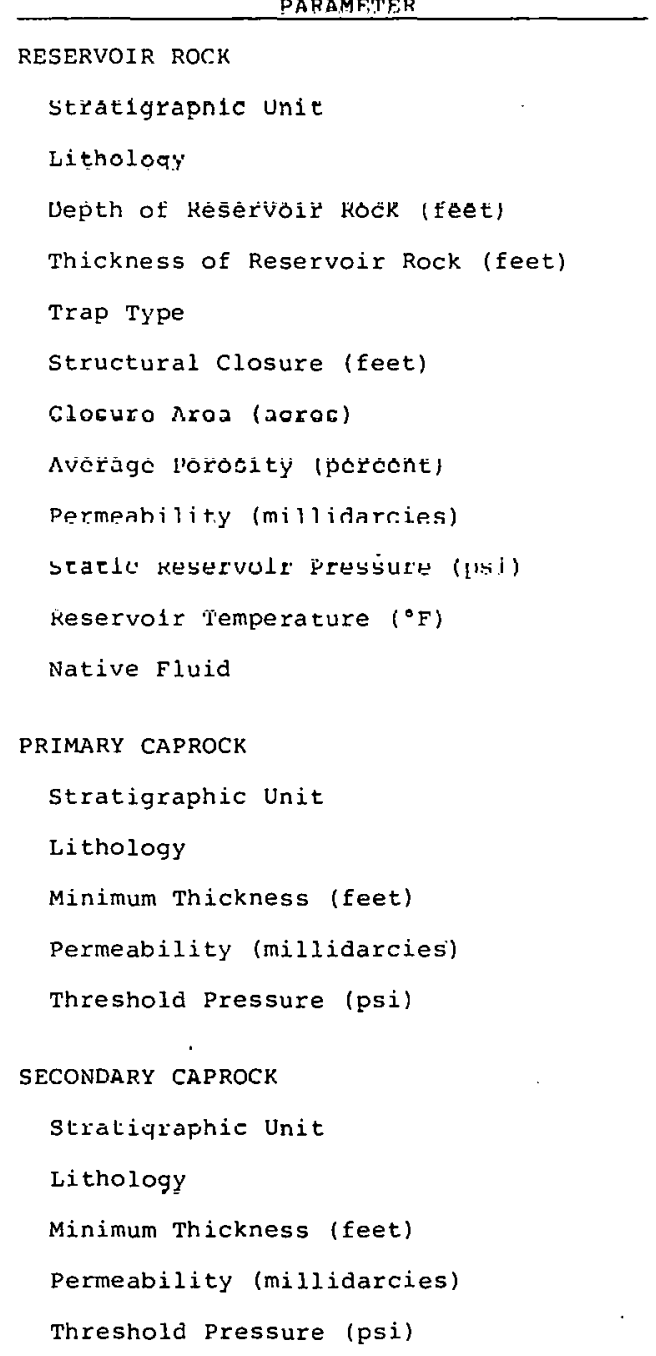

VATLIF.

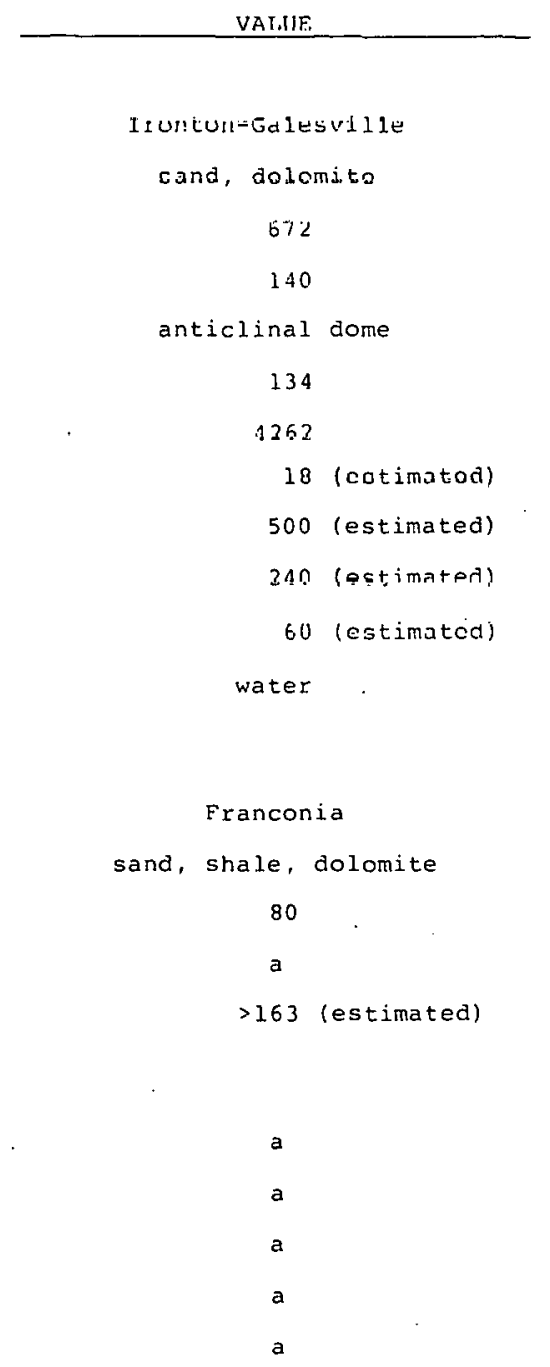

Source: Treworgy (1), based on General Electric Company (2) except for closure area and potential capacity, which are calculated values.

${ }_{\text {No }}$ data available. 
TABLE B-3

RESERVOIR DATA FOR COMPRESSED AIR STORAGE AT THE

DE LAND SITE IN PIATT COUNTY, ILLINOIS,

LOCATED IN SECTION 8, TOWNSHIP 19 NORTH, RANGE 5 EAST

PARAMETER

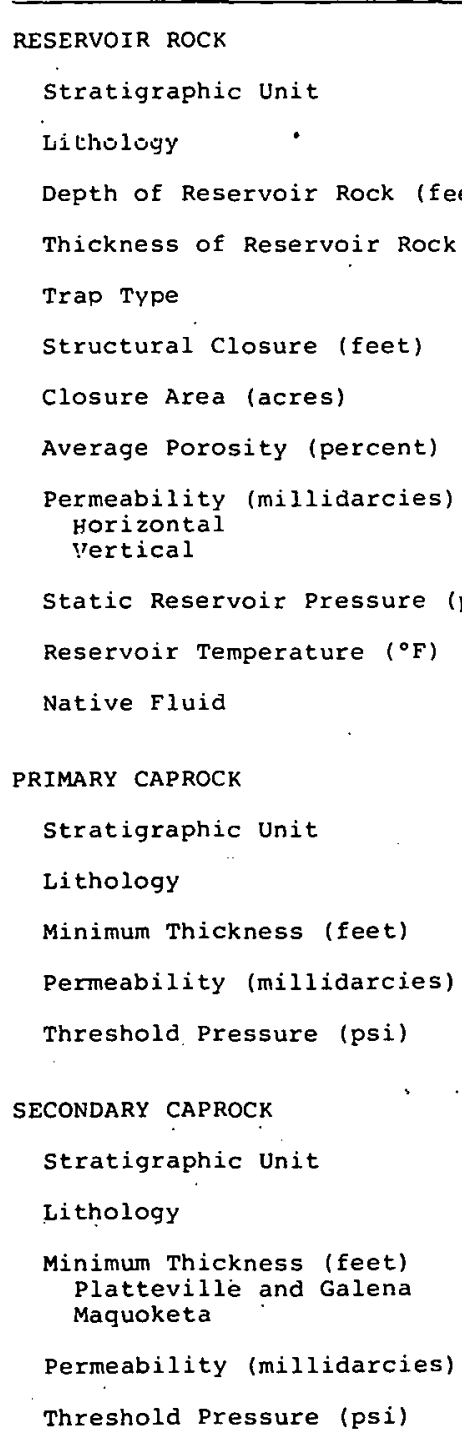

VALUE

St. Peter

รลกส

$-2350$

-200 (estimated $^{a}$

dome

68

1479

$16.6^{\mathrm{a}}$

$377^{\mathrm{a}}$
$475^{\mathrm{a}}$

940 (estimated) $^{a}$

87

water

Joachim

silty, argillaceous dolomite

-40 to 60

$2.33 \times 10^{-4^{a}}$ to $2 \times 10^{-6^{a}}$

generally $>800^{\mathrm{a}}$.

Platteville and Galena, Maquoketa carbonates, shale.

$$
\begin{gathered}
-400 \\
-200 \\
3.81 \times 10^{-4 a} \text { to } 4 \times 10^{-6 a} \\
700^{a} \text { to }>800^{a} \text { in lower } 15 \text { feet }
\end{gathered}
$$

Source: Treworgy (1).

astimated from data available at the Parnell site. 
TABLE B-4

RESERVOIR DATA FOR COMPRESSED AIR STORAGE AT THE

FISHHOOK SITE IN PIKE AND ADAMS COUNTIES, ILLINOIS, LOCATED

IN SECTION 32, TOWNSHIP 3 SOUTH, RANGE 4 WEST

\section{PARMETER}

\section{RESERVOIR ROCK}

Stratigraphic lnit

Lithology

Dopth of haserwoir knok (teet)

Thickness of Reservoir Rock (feet)

Trap Type

Structural closure (feet)

rinsure Area (arires)

Average Purusity (percent)

Permeability (millidarcies) Horizontal Vertical

Static Reservoir Pressure (psi)

Reservoir Temperature $\left({ }^{\circ} \mathrm{F}\right)$

Native Fluid

PRIMARY CAPROCK

Stratigraphic unit

Lithology

Minimum Thickness (feet)

Permeability (millidarcies)

Threshold Pressure (psi)

SECONDARY CAPROCK

Stratigraphis Init

r.ithningy

Minimum Thickness (feet)

Permeability (millidarcies)

Threshold Pressure (psi)
VALUEE

VALUE
St. Peter
sand
291
200
anticline
71
11,733
19.1
892
673
300 (estlildted)
70 (estimated)
water

dolomite with shale streaks

28

a

a

Platteville

limestone with shale streaks

67

a

a

Source: Treworgy (1).

Note: Values are for within the -220 contour.

$a_{\text {No data available. }}$ 


\section{CAES-T2}

TABLE B-5

RESERVOIR DATA FOR COMPRESSED AIR STORAGE AT THE

HUME SITE IN EDGAR COUNTY, ILLINOIS,

LOCATED IN SECTION 24, TOWNSHIP 16 NORTH, RANGE 14 WEST

PARAMETER

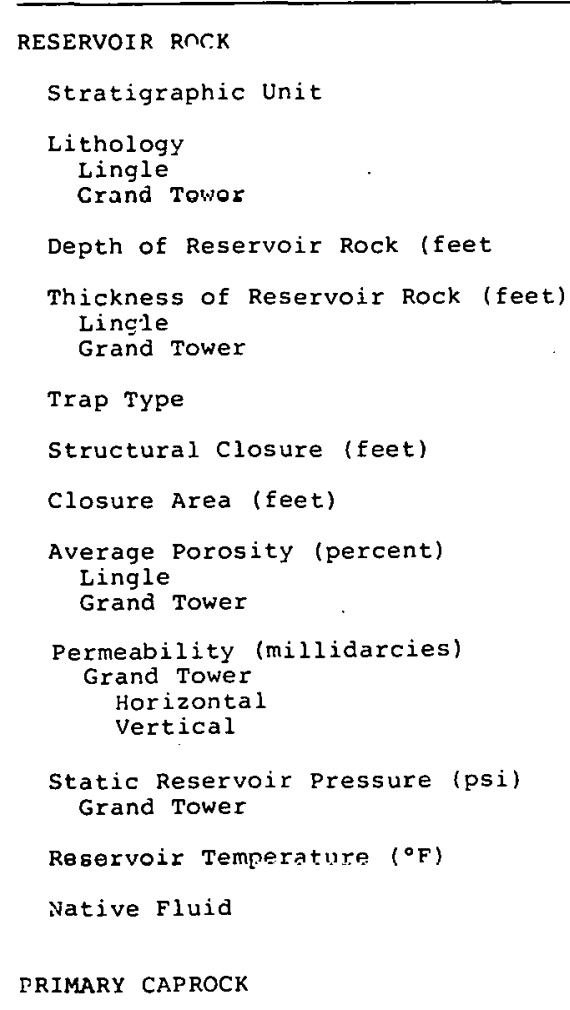

Stratigraphic Unit

Lithology

Minimum Thickness (feet)

Permeability (millidarcies)

Threshold Pressure (psi)

SECONDAR CAPROCK

Stratigraphic Unit

Lithology

Minimum Thickness (feet)

Permeability (millidarcies)

Threshold Pressure (psi)
VALUE

Lingle and Grand Tower

dense limestone

sandy dolomite

$6>0$

50
130

asymetrical anticline

$136\left(150^{\mathrm{a}}\right)$.

$6,500\left(7,600^{a}\right)$

$12 \cdot 4$

5.7
15.0

$540^{a}, \mathrm{c}$ to $8,850^{a}, \mathrm{c}$

$3 \varepsilon^{b} \mathrm{~b}$

241

$67^{\circ}$

water

New Albany-Hannibal

shale

.102

$1 \times 10^{-6}$ to $6 \times 10^{-2}$

$0.1^{\text {a }}$ to $4.0^{a}$

25 to $>800$ (generally $>800$ )

Source: Treworgy ( 1 ) and Peoples Gas, Light and Coke (3).

${ }^{a}$ Source: URS corporation (4) ).

tFrom core analysis report.

c From pump test.

$\mathrm{d}_{\text {No }}$ data available. 
TABLE B-6

RESERVOIR DATA FOR COMPRESSED AIR STORAGE AT THE

LEWIS SITE IN SULLIVAN COUNTY, INDIANA,

LOCATED IN SECTION 9, TOWNSHIF 9 NORTH, RANGE 8 WEST

\section{FARAMETER}

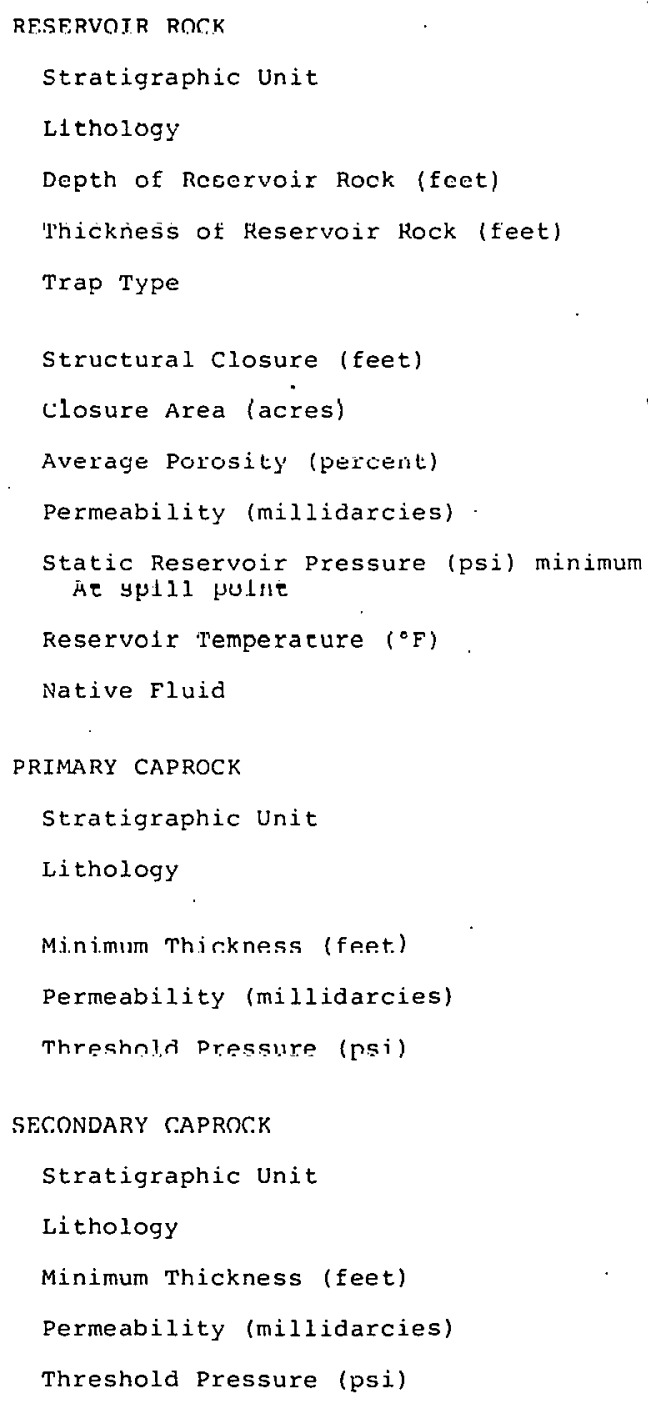

\section{VAIUS:}

Mansfield
sanastone
509
10u to 269
structural closure associated with
Devonian reef
90
553
$20^{a}$
$250 \quad$ to $400^{b}$
$240^{\circ}$
240
$\sqsubset$
water

Mansfield

silty shale to shale with thin shaly sand interbeds

35

c

r.

Manfield

interbedded shale, sand, and coal

$$
\begin{aligned}
& 400 \\
& C \\
& C
\end{aligned}
$$


TABLE B-7

RESERVOIR DATA FOR COMPRESSED AIR STORAGE AT THE

MEDIA SITE IN HENDERSON COUNTY, ILLINOIS, LOCATED

IN SECTION 17, TOWNSHIP 9 NORTH, RANGE 4 WEST

PARAMETER

RESERVOIR ROCK

Stratigraphic Unit

Litholue:

Depth of Reservoir Rock (Eeet)

Thickness of Reservoir Rock (feet)

Trap Type

Structural closure (fieet)

Closure Àrea (acres)

Average porosity (percent)

Permeability (millidarcies) Horizontal

lertical

Static Reservoir Pressure (psi)

Reservoir Temperature ( $\mathrm{F}$ )

Native Fluid

FRISLARY CNPROCK

Stratigraphic unit

Litholog:

Minimum Thickness (feet)

Permeability (millidarcies)

Threshold Pressure (psi)

SECONDARY CAPROCK

Stratigraphic unit

Lithology

Minimum Thickness (feet)

Permeability (millidarcies)

Threshold Pressure (psi)
VALUE

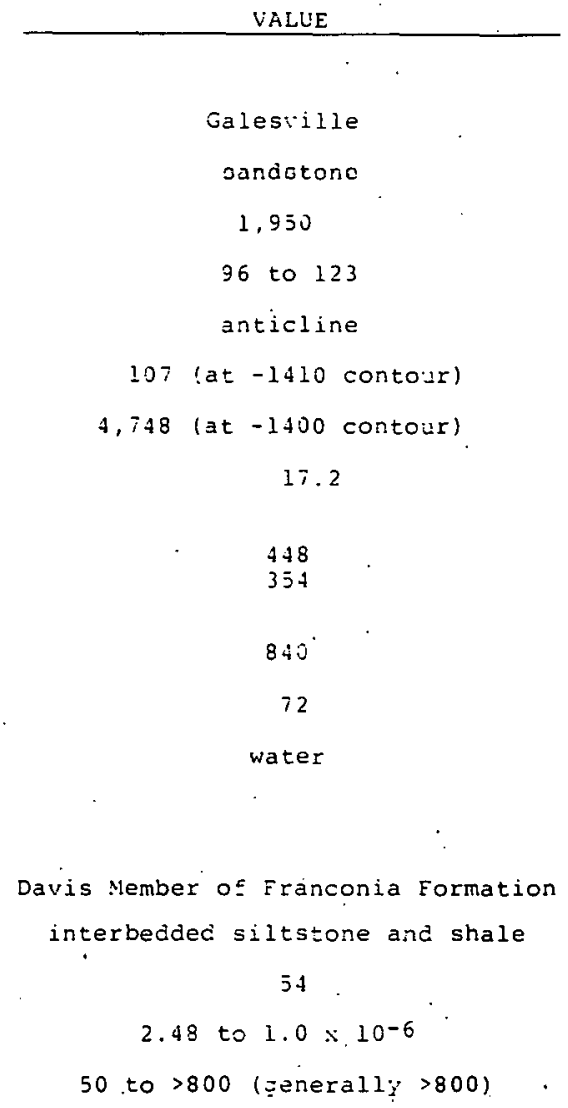

a

$\exists$

a

$a$

a

Source: Treworgy (1).

${ }^{a}$ No data available. 
TABLE $B-8$

RESERVOIR DATA FOR COMPRESSED AIR STORAGE AT THE

PARNELL SITE IN DEWITT COUNTY, ITTTTNOTS, LOCATED

IN SECTION 3, TOWNSHIP 20 NORTH, RANGE 4 EAST

\section{PARAMETER}

RESERVOIR ROCK

Stratigraphic Unit

Lithology

vepth of keservolr Rock (Eeet)

Thickness of Reservoir Rock (feet.)

Trap Type

Structural Closure (feet)

Clusule ines (acies)

Upper 50 feet olily

Averagc Porocity (porsent)

Upper 50 feet only

Permeability (millidarcies)

Horisontal

Vertical

Upper 50 feet only

Horizontal

Vertical

Static Reservoir Pressure (psi)

Reservoir Temperature $\left({ }^{\circ} \mathrm{F}\right)$

Native Fluid

PRIMARY CAPROCK

stratigraphic unit

idcliuluyy

Minimum Thickness (Eeet)

Permeability (millidarcies)

iniesnold pressure (psi)

SECONDARY CAPROCK

Stratigraphic Unit

Lithology

Minimum Thickness (feet)

Platteville and Galena

Maquoketa

Permeability (millidarcies)

Threshold Pressure (psi)
VALUE

VALUE
st. Peter
sand
3,273
-200

dog-leg anticline

143

12.448

2,345

$14: 73$

16.8

217
270

457

573

900

85 (estimated)

water

Joachim

si.jty, argillarenus dolomite

50

$2.33 \times 10^{-4}$ to $2 \times 10^{-6}$

genera $\{1\}>800$

Platteville and Galena, Maquoketa carbonates, shale

\section{$-400$}

200

$3.81 \times 10^{-4}$ to $4 \times 10^{-6}$ in lower 15 feet

700 to $>800$ in lower 15 feet

Source: Treworgy ( 1 ). 
TABLE B-9

RESERVOIR DATA FOR COMPRESSED AIR STORAGE AT THE

PAXTON SITE IN SULLIVAN COUNTY, INDIANA, LOCATED

IN SECTION 33, TOWNSHIP 7 NORTH, RANGE 9 WEST

PARAMETER

RESERVOIR ROCK

Stratigraphic Unit

Lithology

Depth of Reservoir Rock (feet)

Thickness of Reservoir Rock (feet)

Trap Type

Structural Closure (feet)

Closure Area (acres)

Average Purusily (percent)

Permeability (millidarcies)

Static Reservoir Pressure (psi)

Reservoir Temperature $\left({ }^{\circ} \mathrm{F}\right)$

Native Fluid

PRIMARY CAPROCK

Stratigraphic Unit

Lithology

Minimum Thickness (feet)

Permeability (millidarcies)

Threshold Pressure (psi)

SECONDARY CAPROCK

Stratigraphic Unit

Lithology

Minimum Thickness (feet)

Permeability (millidarcies)

Threshold Pressure (psi)
VALUE

VAlue
Hardinsburg
sandstone
930
51 to 73
erosional truncation
62718 to $20^{\mathrm{a}}$
18 to $250^{\mathrm{b}}$
372
c
water

$$
\begin{gathered}
\text { Mansfiela } \\
\text { shale } \\
10 \\
\text { c }
\end{gathered}
$$

Pennsylvanian

interbedded shale, sandstone, and coal 1000

c

$c$

Source: Keith (5).

${ }^{a}$ Based on limited data from other areas.

$b_{\text {In other areas. }}$

${ }^{\text {No data available. }}$ 
TABLE $B-10$

RESERVOIR DATA FOR COMPRESSED AIR STORAGE AT THE

PRATRTE CREEK SITE IN VIGO COUNTY, INDIANA, LOCATED

IN SECTIONS 15 AND 16, TOWNSHIP 10 NORTH, RANGE 10 WEST

PARAMETER

RESERvulk kuCK
Stratigraphic Unit
Lithology
Depth of Reservoir Rook (teot)
Thickness of Reservoir Rock (feet)
Trap Type
Structural Closure (feet)
Clonure nrni (arros)
Average Porosity (percent)
Permeability (millidarcies)
Static Reservoir Pressure (psi) minimum
At spill point
Reservoir Temporature (of)
Native Fluid

PRIMARY CAPROCK

Stratigraphic Unit

Lithology

Minimum Thickness (feet)

Fermeability (nillidarcies)

Threshold Pressure (psi)

SECONDARY CAPROCK

Stratigraphic Unit

Lithology

Minimum Thickness (feet)

Permeability (millidarcies)

Threshold Pressure (psi)
VAT,LITE.

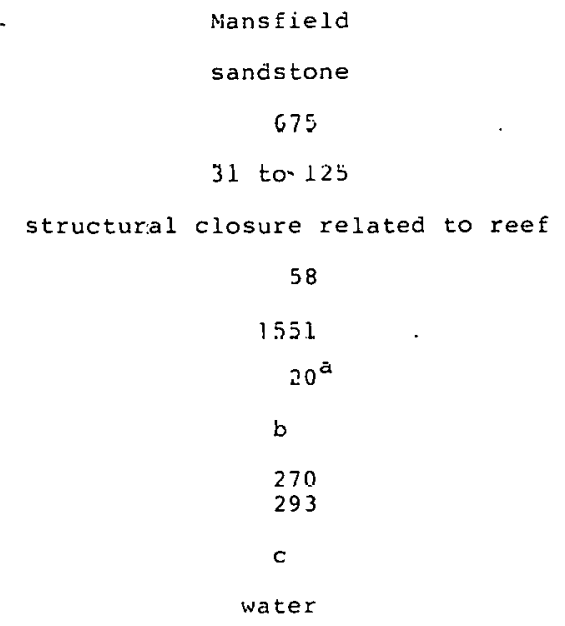

Mansfield silty shale

70

c

$c$

Pennsylvanian

shale with sand and thin coal beds 500

c

c

Source: Keith (ㅁ).

astimated from other areas.

bunknown, but probably in hundreds of millidarcies.

No data available. 
TABLE B-11

RESERVOIR DATA FOR COMPRESSED AIR STORAGE AT THE

TOUILON A SITE IN HENRY COUNTY, ILLINOIS, LOCATED

IN SECTION 26, TOWNSHIP 14 NORTH, RANGE 5 EAST

\section{PARAMETER}

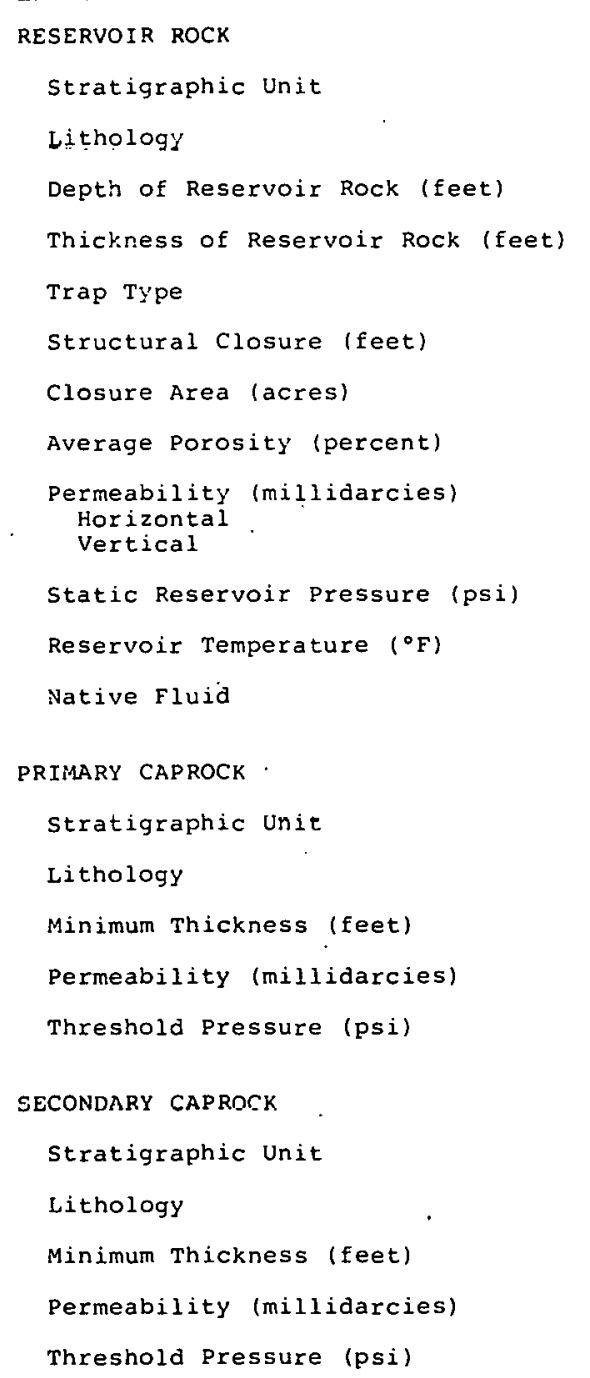

VALUE

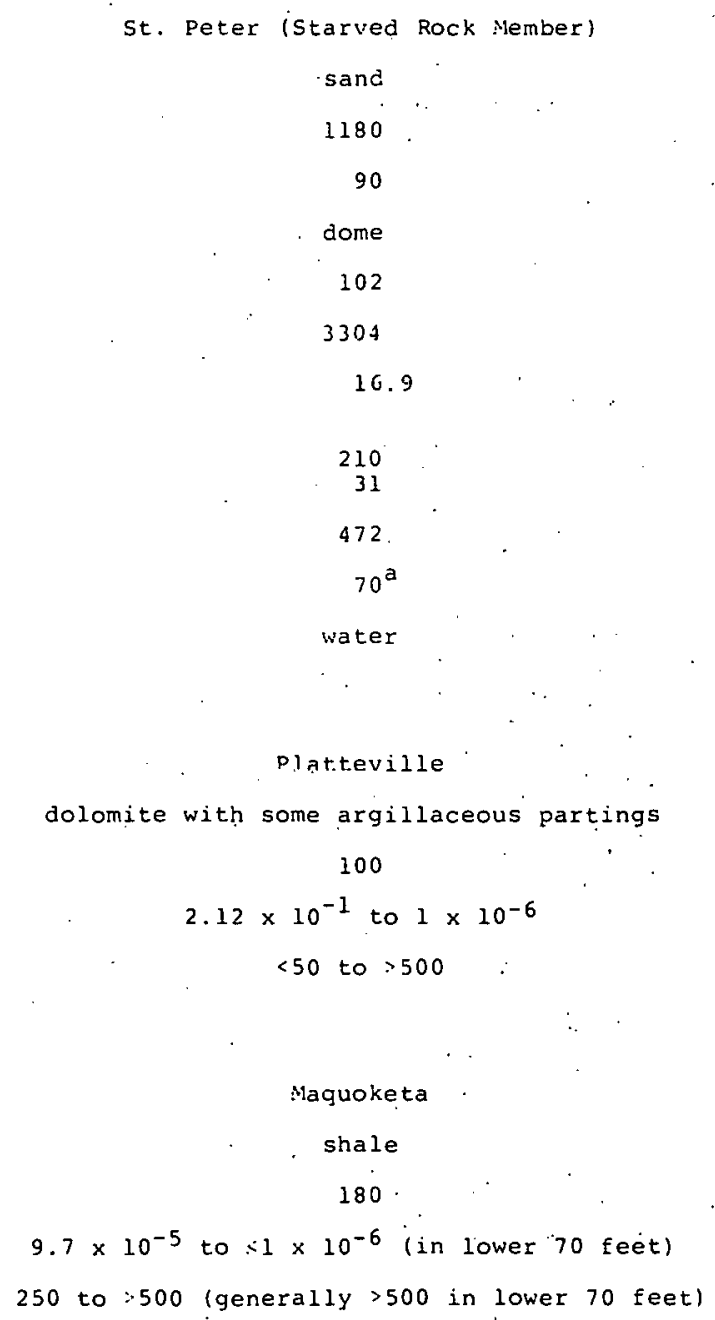


TABLE B-12

RESERVOIR DATA FOR COMPRESSED AIR STORAGE AT THE

'IUUIJON B SITE IN STARK COUNTY, ILLINOIS, LOCATED

IN SECTION 11, TOWNSHIP 13 NORTH, RANGE 5 EAST

PARAMETER

\section{RESERVOIR ROCK}

Stratigraphic unit

Lithology

Depth of Reservoir Rock (feet)

Thickness of Reservoir Rock (feet)

Trap Type

Structural closure (feet)

Closure Area (acres)

Averagge porosicy (percent)

Permeability (millidarcies)

Horizontal

Vertical

Static Reservoir Pressure (psi)

Reservoir Temperature ( $\left.{ }^{\circ} \mathrm{F}\right)$

Native Fluid

PRIMARY CAFROCK

Stratigraphic Unit

Lithology

Minimum Thickness (feet)

Permeability (millidarcies)

Threshold pressure (psi)

SECONDARY CAPROCK

Stratigraphic Unit

Lithology

Minimum Thickness (feet)

Permeability (millidarcies)

Threshold Pressure (psi)
VALUE

St. Peter (Starved Rock Member)

sand

1150

90

dome

87

2045

16.9

210

31

460

$70^{a}$

water

Platteville

dolomite with some argillaceous partings

100

$2.12 \times 10^{-1}$ to $1 \times 10^{-6}$

$\therefore 50$ to $>500$

Maquoketa

shate

180

$9.7 \times 10^{-5}$ to $\because 1 \times 10^{-6}$ (in lower 70 feet)

250 to $\therefore 500$ (generally $>500$ in lower 70 feet)

Source: Treworgy (1).

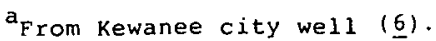


TABLE $\quad B-13$

RESERVOIR DATA FOR COMPRESSED AIR STORAGE AT THE

WADESVILLE WEST SITE IN POSEY COUNTY, INDIANA, LOCATED

IN SECTION 11, TOWNSHIP 5 SOUTH, RANGE 13 WEST

\section{PARAMETER}

\section{RESERVOIR ROCK}

Stratigraphic Unit

Li thology

Depth of Reservoir Rock (feet)

Thickness of Reservoir Rock (feet)

Trap Type

structural Closure (feet)

Closure Area (acres)

Averag̣e Porosity (percent)

Permeability (millidarcies)

Static Reservoir Pressure (psi) minimum At spill point

Reservoir Temperature $\left({ }^{\circ} \mathrm{F}\right)$

Native Fluid

PRIMARY CAPROCK

Stratigraphic Unit

Lithology

Minimum Thickness (feet)

Permeability (millidarcies)

Threshold Pressure (psi)

SECONDARY CFPROCK

Stratigraphi,c Unit

Lithology

Minimum Thickness (feet)

Permeability (millidarcies)

Threshold Pressure (psi)

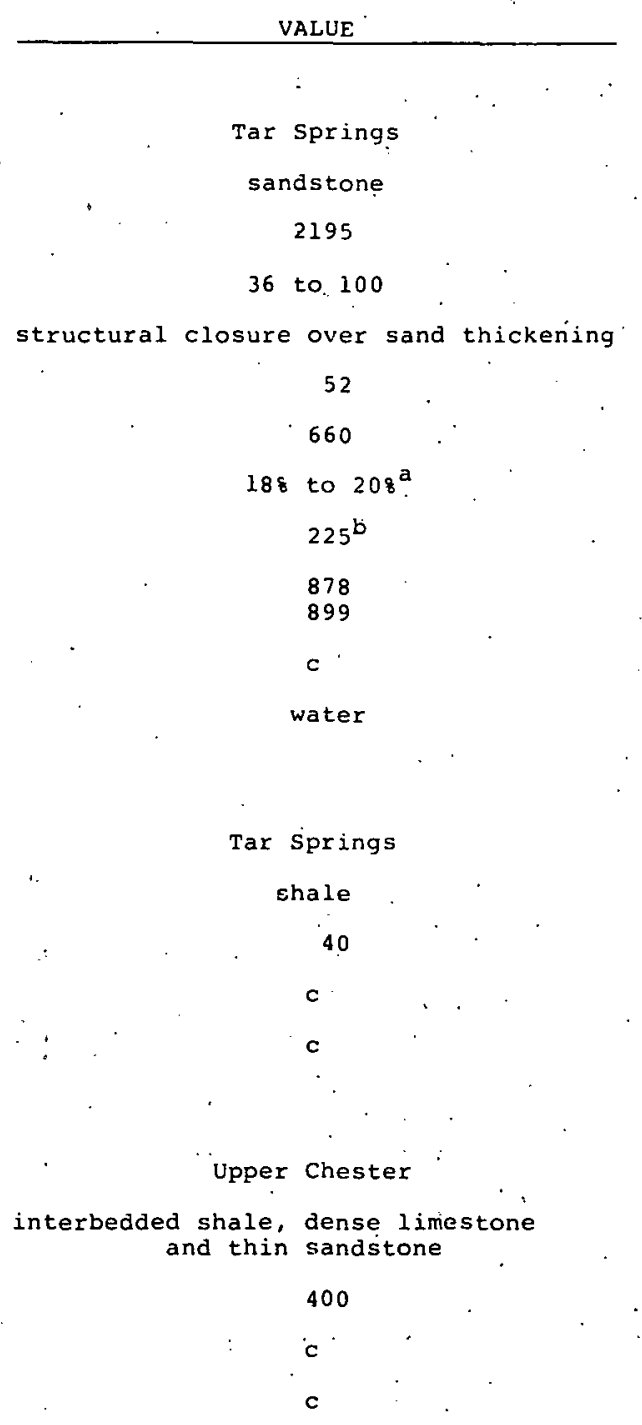

Source: Keith ().

astimated from other areas..

${ }^{b}$ From other areas in Posey county.

${ }^{\text {No }}$ data available. 
TABLE $\quad B-14$

RESERVOIR DATA FOR COMPRESSED AIR STORAGE AT THE

WAPELLA EAS'I' SI'I'E IN DE'WI'L"I' COUN'IYY, ILLLNOLS, LOCATEED

IN SECTION 28, TOWNSHIP 21 NORTH, RANGE 3 EAST

PARAMETER

RESERVOIR ROCK

Strațigraphic Unit

Lithology

nenth nf keservnir knsk (feet.) ,

Thickness of Reservoir Rock (feet)

Trap Type

Structural closure (feet)

Closure Area (acres)

Average Porosity (percent)

Permeability (millidarcies)

Hoi izontal

Vertical

Static Reservoir Prossure (psi)

Reservoir Temperature $\left({ }^{\circ} \mathrm{F}\right)$

Native Fluid

PRIMARY CAFROCK

Stratigraphic Unit

Lithology

Minimum Thickness (feet)

Permeability (millidarcies)

Threshold Pressure (psi)

SECONDARY CAPROCK

Stratigraphic Unit

Lithology

Minimum Thickness (feet)

Platteville and Galena

Maquoketa

Permeability (millidarcies)

Threshold Pressure (psi)
VALLE

St. Peter

sand

2162

200 (estimated) $^{2}$

dome

80

1844

16.1 a

$331^{\mathrm{a}}$

$880^{a}$

84 (estimated)

water

Joachim

silty, argillaceous dolomite

40

$2.33 \times 10^{-4^{a}}$ to $2 \times 10^{-6^{a}}$

generally $>800^{a}$

Platteville and Galena, Maquoketa carbonates, shale

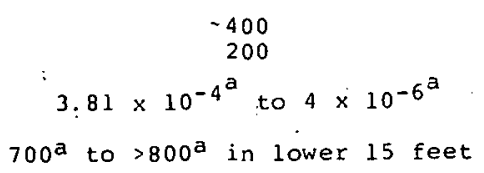

Source: Treworgy (ㅁ) .

astimated from data available at the Parnell site.

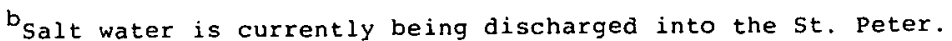


REFERENCES

1. J. D. Treworgy, Assistant Geologist, Illinois state Geological Survey, Urbana, Illinois. Transmittal on March 14, 1979, of Data Sheets to A. K. Yonk, Senior Geologist, Sargent \& Lundy, Chicago, Illinois.

2. General Electric Company. "Economic and Technical Feasibility Study of Compressed Air Storage.". Schenectady, New York: U.S. Energy Research and Development Administration, 1976. No. E(11-1)-2559. ERDA 76-76.

3. Peoples Gas, Light, and Coke Company, Peoples Gas, Light, and Coke Company Docket to Illinois. Commerce Commission for Hume site. Springfield, Illinois, September 1972. Docket No: 57619 .

4. URS Corporation. Personal Communication in 1978 to Illinois state Geological Survey.

5. B. D. Keith, Geologist, Indiana Geological Survey, Bloomington, Indiana. Transmittal on February 19, 1979 ; of Data Sheets to A. K. Yonk, Senior Geologist, Sargent \& Lundy, Chicago, Illinois.

6. R. Hanson. "Public Ground Water Supplies in Illinois." Urbana, Illinois: Illinois state Water Survey, 1950.. Bulletin 40 . 


\section{CAES-T2}

\section{Attachment $\mathrm{C}$ \\ REPORT COST ESTIMATES}

\section{CONTENTS}

Table

C-1 Summary Report Cost Estimate

C-2 Detail Report cost Estimate $\underline{\text { Page }}$

$\mathrm{C}-1$

c-5 
GENERAL DATA

\begin{tabular}{|c|c|c|c|c|c|c|c|c|c|}
\hline $\begin{array}{l}\text { Sitess. } \\
\text { (Reservoir: Rock) }\end{array}$ & $\begin{array}{l}\begin{array}{c}\text { Detand } \\
\text { ist. Peter) }\end{array} \\
\end{array}$ & $\begin{array}{r}\begin{array}{r}\text { Wapel1a } \\
\text { East } \\
\text { (st: Peter) }\end{array} \\
\end{array}$ & $\begin{array}{c}\text { Media } \\
\text { (Galesville) }\end{array}$ & 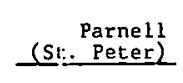 & $\begin{array}{c}\text { Toul on A } \\
\text { (st. Peter) } \\
\end{array}$ & $\begin{array}{c}\begin{array}{c}\text { Brookville } \\
\text { (Galesville) }\end{array} \\
\end{array}$ & $\begin{array}{c}\begin{array}{l}\text { Fishhook } \\
\text { (st. Peter) }\end{array} \\
\end{array}$ & $\begin{array}{l}\text { Brocton } \\
\text { (crand Tower) }\end{array}$ & $\begin{array}{l}\text { (Grand Hune } \\
\text { Hower) }\end{array}$ \\
\hline 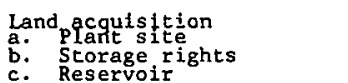 & $\begin{array}{l}2,022 \text { acre } \\
305 \text { acre } \\
3,214 \text { acre }\end{array}$ & 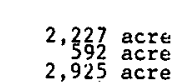 & $\begin{array}{l}2,838 \text { acre } \\
5,1163 \text { acre }\end{array}$ & 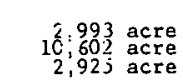 & 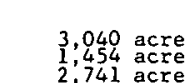 & $\begin{array}{l}\text { 4, 631 acre } \\
\text { ?88 acree }\end{array}$ & $\begin{array}{l}7,370 \text { acre } \\
6,233 \text { acre }\end{array}$ & 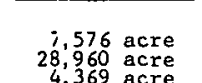 & \\
\hline $\begin{array}{l}\text { Total plane capacity } \\
\text { for cost estimate }\end{array}$ & & $1,000 \mathrm{Nw}$ & $00 \mathrm{MH}$ & & 1,000 & $1,000 \mathrm{mw}$ & $000 \mathrm{rw}$ & & \\
\hline & $\begin{array}{l}\text { Luke } \\
\text { chintor }\end{array}$ & $\begin{array}{l}\text { Lalke } \\
\text { clinton }\end{array}$ & & $\begin{array}{l}\text { lake } \\
\text { ciinnon }\end{array}$ & $\begin{array}{l}\text { Damu Acrivs } \\
\text { Naturat Water }\end{array}$ & Perchied Pond & Parchad Pond & $\begin{array}{l}\text { Dan } A \\
\text { Natura } \\
\text { Natura }\end{array}$ & \\
\hline volune & 14,000 & $13,000 \mathrm{ac}-\mathrm{ft}$ & $425 \mathrm{ac}-\mathrm{ft}$ & 13,000 & 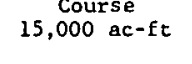 & 425 ac- $-\mathrm{ft}$ & $425 \mathrm{ac}-\mathrm{ft}$ & & \\
\hline $\begin{array}{l}\text { Nulls } \\
\text { Number of wells } \\
\text { Depth (Avg.) } \\
\text { Length of make-up pipeline }\end{array}$ & $\begin{array}{l}165 \mathrm{ea} . \\
2,374.5 \mathrm{ft} . \\
49,100 \mathrm{LF}\end{array}$ & $\begin{array}{l}190 \mathrm{ea} . \\
2,190.3 \mathrm{ft} . \\
51,500 \mathrm{LF}\end{array}$ & $\begin{array}{l}235 \mathrm{ea} . \\
1,970 \mathrm{ft} . \\
59,800 \mathrm{LF}\end{array}$ & $\begin{array}{l}215 \text { ea. } \\
2,292.7 \mathrm{ft} . \\
109,900 \mathrm{LF}\end{array}$ & $\begin{array}{l}975 \mathrm{ea} . \\
1,214.3 \mathrm{ft} . \\
51,200 \mathrm{LF}\end{array}$ & $\begin{array}{l}1,250 \mathrm{ea} . \\
717.6 \mathrm{ft} . \\
80,300 \mathrm{LF}\end{array}$ & $\begin{array}{l}1,200 \mathrm{ea} . \\
1,028.2 \mathrm{ft} . \\
87,200 \mathrm{LF}\end{array}$ & $\begin{array}{l}9,00 \text { ea. } \\
65: 7 \mathrm{ft} . \\
28,000 \mathrm{LF}\end{array}$ & \\
\hline
\end{tabular}

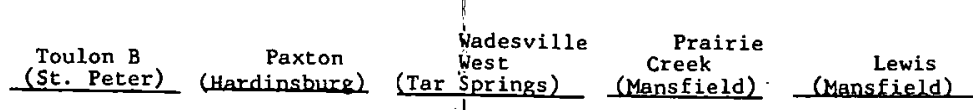

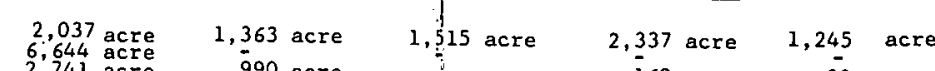
$\begin{array}{lllll}2,741 \text { acre } & 990 \text { acre } & 1 & 160 \text { acre } & 80 \text { acre } \\ 862 \mathrm{MN} & 693 \mathrm{MWN} & 327 \mathrm{MW} & 246 \mathrm{MW} & 98 \mathrm{NW}\end{array}$ $862 \mathrm{MN} \quad 693 \mathrm{MW} \quad 327 \mathrm{MN} \quad 246 \mathrm{MN} \quad 98 \mathrm{MN}$ Dam Across
Naturaal water 14,000 ac-ft 3,400 ac-ft $\quad 425$ ac-ft $\quad 1,800$ ac-ft 700 ac-ft $\begin{array}{lllll}850 \text { ea. } & 715 \text { ea. } & 170 \text { eá. } & 900 \text { ea. } & 380 \text { ea. } \\ 1,213.2 \mathrm{ft} . & 982.2 \mathrm{ft} . & 2,210 \mathrm{ft} & 695 \mathrm{ft} & 540.1 \mathrm{ft} .\end{array}$ $\begin{array}{lllll}36,650 \mathrm{LF} & 48,200 \mathrm{LF} & 83,800 \mathrm{LF} & 18,900 \mathrm{LF} & 84,700\end{array}$ 


\begin{tabular}{|c|c|c|c|c|c|c|c|c|c|}
\hline & $\begin{array}{c}\text { Sites } \\
\text { SReservoir Rock) }\end{array}$ & 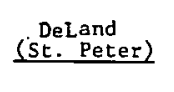 & $\begin{array}{l}\text { Wapella east } \\
\text { SIt. Peterz) }\end{array}$ & $\begin{array}{l}\text { Media } \\
\text { (Galesvil1e) }\end{array}$ & 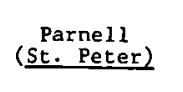 & $\begin{array}{l}\text { Toulon } \mathrm{A} \\
\text { (st. Petetr } r)\end{array}$ & 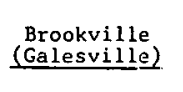 & $\begin{array}{l}\text { Fishhook } \\
\text { (st. Peter) } \\
\end{array}$ & $\begin{array}{l}\text { Brocton } \\
\text { (Grand Tower) }\end{array}$ \\
\hline $\begin{array}{c}\text { Fep.,. } \\
\text { Account No. }\end{array}$ & Description & & & & & & & & \\
\hline 310 & Land and Land Rights & & & & & & & & \\
\hline $\begin{array}{l}: 1 \\
: 11\end{array}$ & 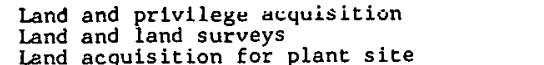 & $\$ 6,065,000$ & $\$ 6,680,000$ & $\$ 8,515,000$ & $\$ 8,980,000$ & $\$ 9,120,000$ & $\$ 13,895,000$ & $\$ 22,1100,000$ & \\
\hline .112 & 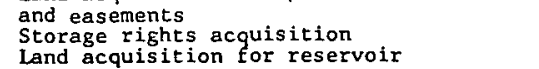 & $\begin{array}{r}95,000 \\
9,645,000 \\
\end{array}$ & $\begin{aligned} 8,80,000 \\
8,775,000\end{aligned}$ & $1,550,000$ & $\begin{array}{l}3,180,000 \\
8,775,000\end{array}$ & $\begin{array}{l}400,000 \\
8,225,000\end{array}$ & 240,000 & $\begin{array}{r}926,1,80,000 \\
1,870,000\end{array}$ & \\
\hline & TOTAL 310.1 & $\$ 15,805,000$ & $\$ 15,635 ; 000$ & $\$ 10,065,000$ & $\$ 20,935,000$ & $\$ 17,785,000$ & $\$ 14,135,000$ & $\$ 23,980,000$ & \\
\hline .2 & 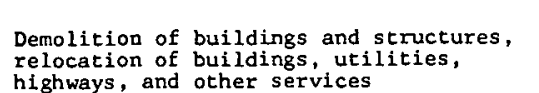 & $3,335,000$ & 360,000 & 15,000 & 765,000 & 150,000 & - & 25,000 & $\longleftarrow$ See Note 6 on Page $\mathrm{C}-4$ \\
\hline & TOTAL 310 & $\$ 19.140,000$ & $\$ 15,995,000$ & $\$ 10,080,000$ & $\$ 21,700,000$ & $\$ 17,935,000$ & $\$ 14,135, \cap \cap 0$ & $\$ 21,005,000$. & \\
\hline 311 & Structures and Improvements & & & & & & & & \\
\hline .1 & 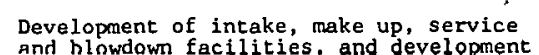 & $8,510,000$ & $6,155,000$ & $2,215,000$ & $6,730,000$ & $6,220,000$ & $2,350,000$ & $3,550,000$ & \\
\hline$: 2$ & 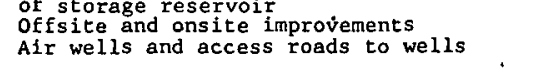 & $\begin{array}{l}4,100,000 \\
45,345,000 \\
\end{array}$ & $\begin{aligned} 4,595,000 \\
49,090,000 \\
\end{aligned}$ & $\begin{array}{lll}4 & 4,752,000 \\
55,605,000 & \end{array}$ & $\begin{array}{ll}52,555,000 \\
57,710,000\end{array}$ & $\begin{array}{llll}153,1350,000 \\
.53,34000 \\
\end{array}$ & $\begin{array}{r}88,210,000 \\
137,105,000 \\
\end{array}$ & 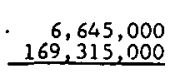 & \\
\hline & TOTAL 311 & $\$ 55,955,000$ & $\$ 59,840,000$ & $\$ 62,545,000$ & $\$ 67,025,000$ & $\$ 164,895,000$ & $\$ 147,665,000$ & $\$ 179,510,000$ & \\
\hline
\end{tabular}

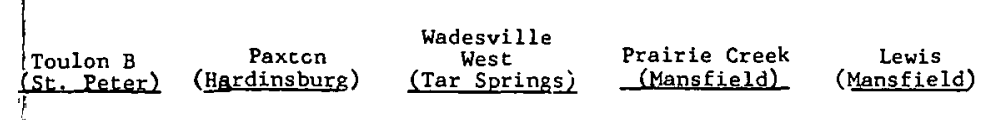

\begin{tabular}{|c|c|c|c|c|}
\hline $\begin{array}{l}\$ 6,120,000 \\
1,995,000 \\
8,25,000\end{array}$ & $\$ 4,090,000$ & $\$ 4,545,000$ & $\$ 7,010,000$ & $\{3,735,000$ \\
\hline 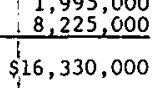 & $2,970,000$ & & 480,000 & 240,000 \\
\hline $16,330,000$ & $\$ 7,060, \mathrm{C}$ & $\$ 4,545,000$ & $\$ 7,490,000$ & $\$ 3,975,000$ \\
\hline 105,000 & $1,950,000$ & 20,010 & $1,375,000$ & 425,000 \\
\hline $16,135,000$ & $\$ 9,010,000$ & $\$ 4,565,000$ & $\$ 8,865, \cap \cap 0$ & $\$ 4,400,000$ \\
\hline $5,970,000$ & $6,640,000$ & $3,185,000$ & $5,525,0000$ & $4,725,000$ \\
\hline 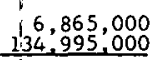 & $\begin{array}{r}2,960,000 \\
98,410 ; 000\end{array}$ & $\begin{array}{r}5,570,000 \\
43,90,0\end{array}$ & $\begin{array}{l}7,310,000 \\
96,735,00\end{array}$ & $\begin{array}{r}3,040,000 \\
34,94 ; 000\end{array}$ \\
\hline 830 , & 3,000,00 & $.655,000$ & $09,570,0$ & 0,0 \\
\hline
\end{tabular}




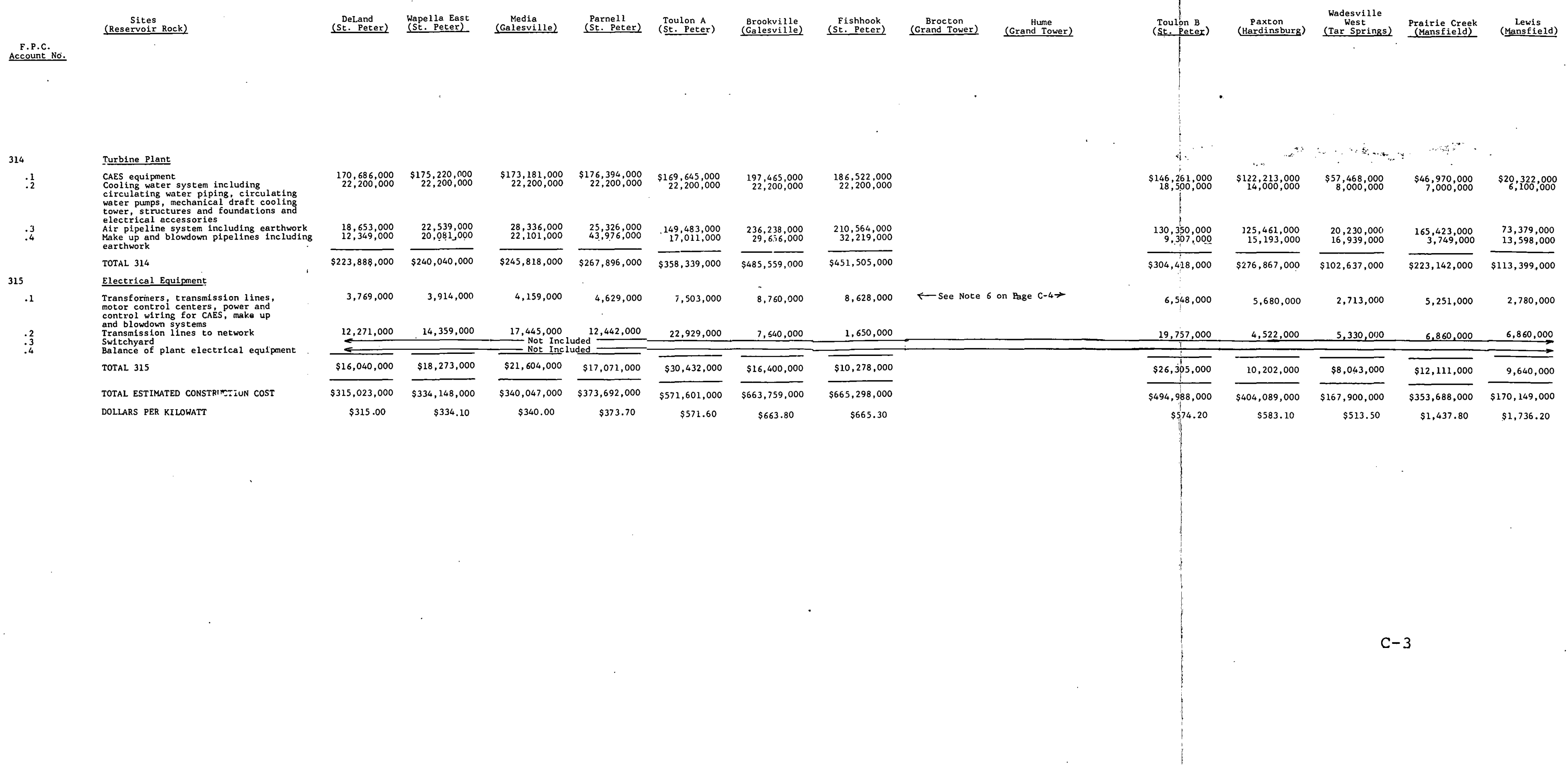


NOTES:

1. Cost for land acquisition for plant site and reservoir were based on an average of $\$ 3,000.00$ per acre; costs for storage rights
acquisitition were based on an average of $\$ 300.00$ per acre.

2. We1l pricing was based on Katz and Lady "Compressed Air Storage" 1976 Report and escalated to March 1979 prices.

3. The following costs are not included in the absed air sedras

a. Indirect expenses.

b. Escalation of equipment, materials, erection and construction labor.

c. Allowance for Funds used During Construction (AFDC).

d. Sales and use taxes.

4. Not included are the structural and electrical facilities for the main power block.

5. Water supply for the Detand, Parnell and wapella East sites is via pipeline from Clinton Lake but the estimate includes a cost for
development of a new reservoir because it may be required.

6. The cost estimates for Brocton and Hune are not included due to the large number of walls calcsulated based on the
exeremely low values of pernability and discovery pressure in pubi ished 
GENERAL DATA

(Reservoir: Rock)

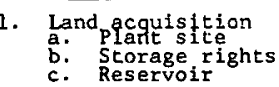

2. Total plane capacity
for cost estimate

chater
Type

volune

4. Wells Number of wel1s

Depth (Avg.)

Length of make-up pipeline

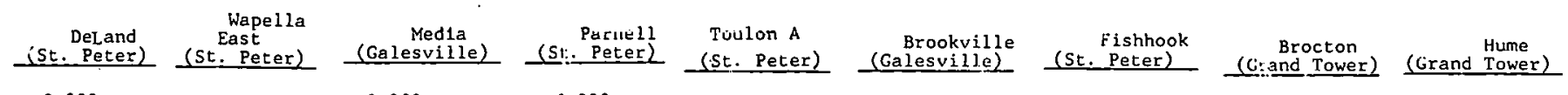

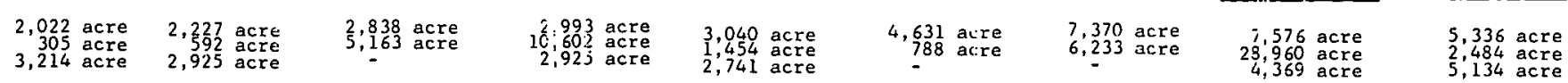

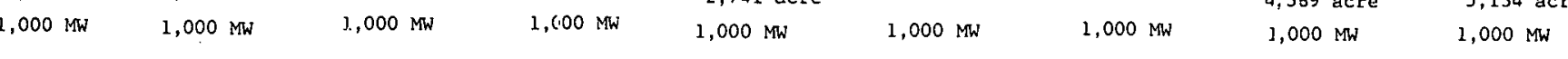

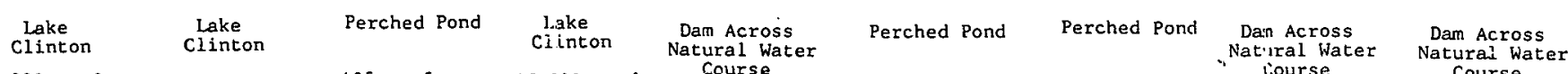

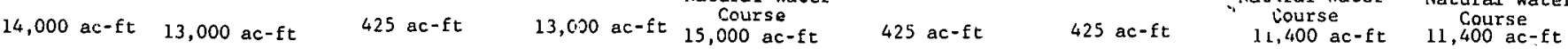

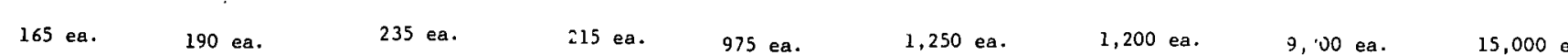

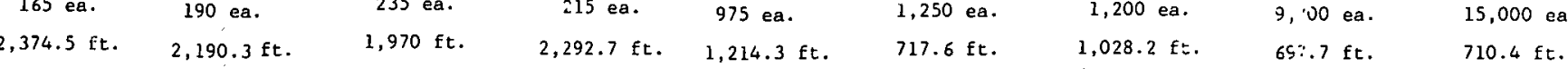
$\begin{array}{lllllllll}49,100 \mathrm{LF} & = \\ 51,500 \mathrm{LF} & 59,800 \mathrm{LF} & 109,900 \mathrm{LF} & 1,214,3 \mathrm{ft} . & 17.6 \mathrm{LF} & 80,300 \mathrm{LF} & 87,200 \mathrm{LF} & 28,000 \mathrm{LF} & 89,600 \mathrm{LF}\end{array}$

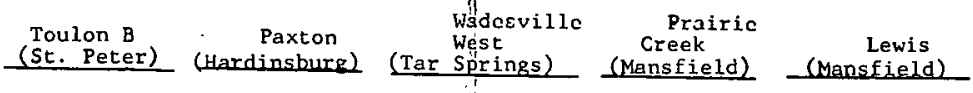

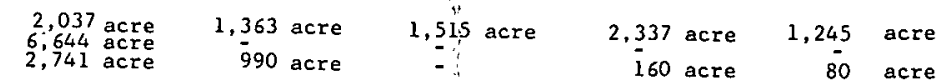
$862 \mathrm{MW} 693 \mathrm{MW} \quad 327, \mathrm{MW} \cdot 246 \mathrm{MN} 98 \mathrm{MW}$

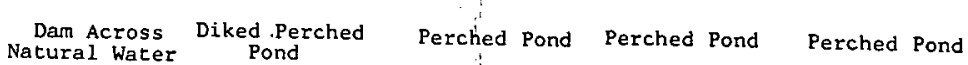
14,000 ac-ft $\quad 3,400$ ac-ft $\quad 425$ ać-ft $\quad 1,800$ ac-ft $\quad 700$ ac-ft

850 еa. 715 еa. $\quad 170$ еа. $\quad 900$ еа. 380 еа.

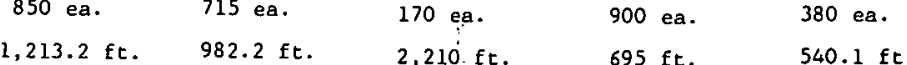

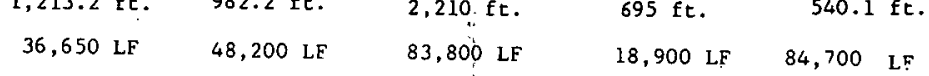


(Reservoir Rock)

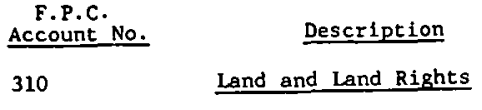

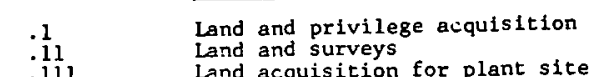

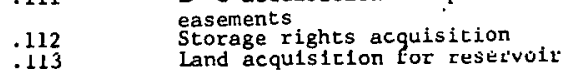

TOTAL 310.11

Clearing
Denolituron of bulldings and
structuruse

structures
TOTAL 310.1

Relocation of buildings utitiities
highways and other services

Power 1 nes

pipes, sewers, gas p pitas
Highways

Re locats
ditch of

culverts
Underground pipelines

TOTAL 310.2

caping of wells. etc.

TOTAL 310

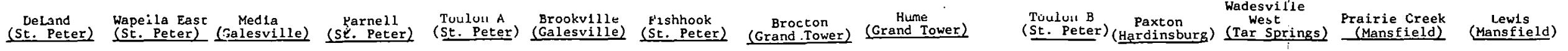

\begin{tabular}{|c|c|c|c|c|c|c|c|c|c|c|c|}
\hline$\$ 6,065,000$ & $\$ 6,680,000$ & $\$ 8,515,000$ & $\$ 8,980,000$ & $\$ 9,120,000$ & $\$ 13,895,000$ & $\$ 22,110,000$ & $\$ 6,110,000$ & $\$ 4,090,000$ & $\$ 4,545,000$ & $\$ 7,010,000$ & $\$ 3,735,000$ \\
\hline $\begin{array}{r}95,000 \\
9,445,000\end{array}$ & $\begin{array}{r}18,750,0000 \\
8,75,000\end{array}$ & $1,550,000$ & $\begin{array}{l}3,180,000 \\
8.777,000 \\
8\end{array}$ & $\begin{array}{l}4,42,0,000 \\
8,225,000\end{array}$ & $.240,000$ & $1,870,000$ & $\begin{array}{r}1,995,000 \\
8,225,000 \\
\end{array}$ & $2,970,000$ & & 480,000 & $24 \overline{0} 0,000$ \\
\hline$\$ 15,805,000$ & $\$ 15,635,000$ & 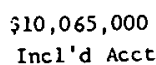 & $\begin{array}{l}520,935,0000 \\
3112.2201\end{array}$ & $\$ 17,785,000$ & $\$ 14,135,000$ & $\$ 23,980,000$ & $\$ 16,330,000$ & $\$ 7,060,000$ & $\$ 4,545,000$ & $\$ 7,490,000$ & $\$ 3,975,000$ \\
\hline 160,000 & 145,000 & $\begin{array}{r}15,000 \\
\end{array}$ & $\begin{array}{r}140,000 \\
\end{array}$ & $\begin{array}{r}50,000 \\
\end{array}$ & $\ldots$ & 25,000 & $\begin{array}{l}55,000 \\
\end{array}$ & 20,000 & $\begin{array}{r}20,000 \\
\end{array}$ & $\begin{array}{l}30,000 \\
\end{array}$ & 20,000 \\
\hline & & & & & $4,135,000$ & $\$ 24,005,000$ & $\$ 16,385,000$ & , 080,000 & $\$ 4,565,000$ & $\$ 7,520,000$ & $\$ 3,96$ \\
\hline
\end{tabular}

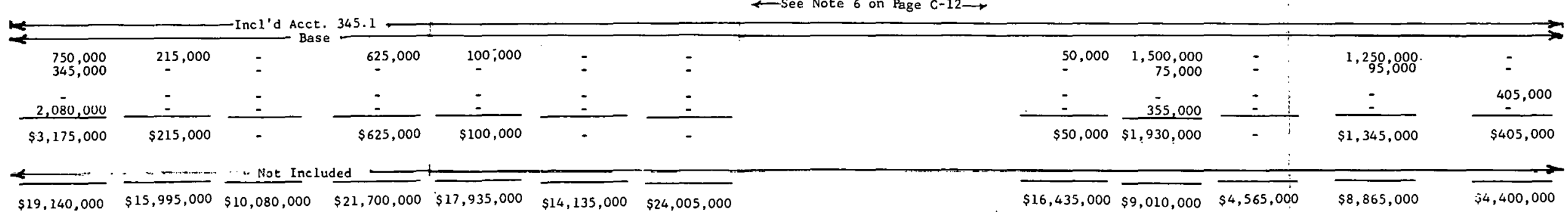




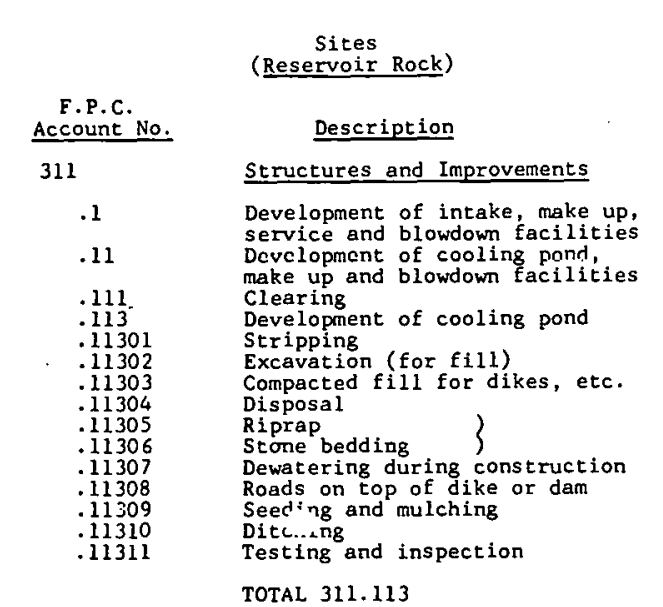

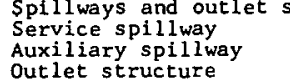
TOTAL 311.114 TOTAL 311.11

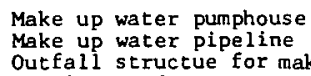
pipeline Outfoll structure $f:$ : outfall pipel ine TOTAL 311.1

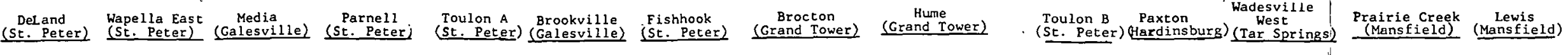

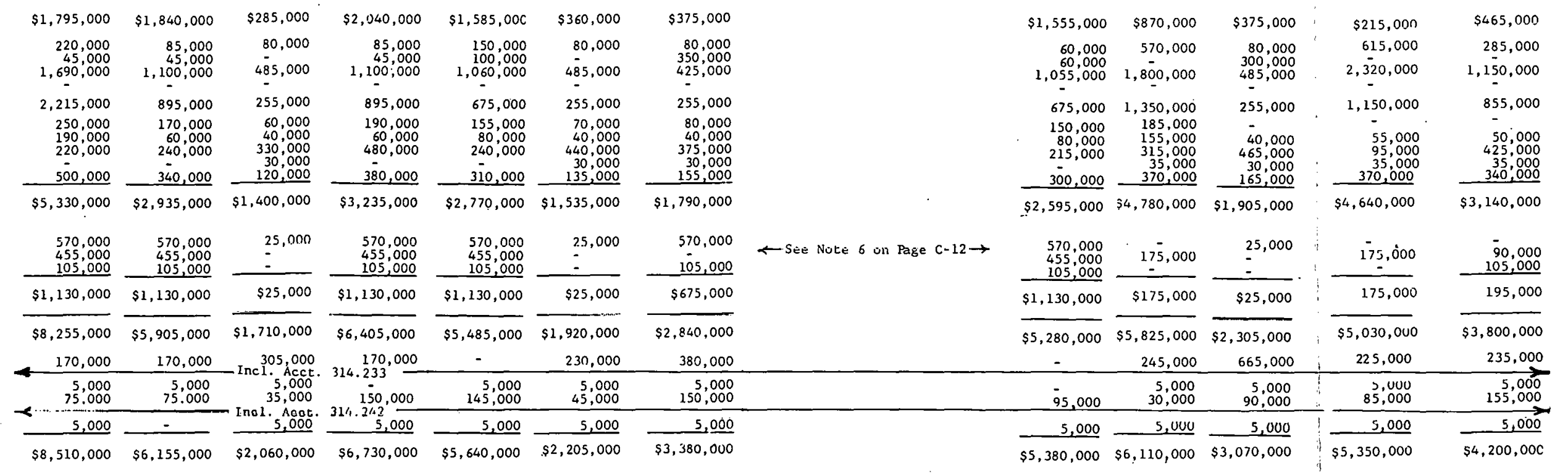




\begin{tabular}{|c|c|c|c|c|c|c|c|c|c|}
\hline \multirow{3}{*}{$\begin{array}{l}\text { E.P.C. } \\
\text { Accounc No. } \\
311\end{array}$} & $\begin{array}{l}\text { Sites } \\
\text { (Reservoir Rock) }\end{array}$ & 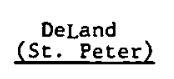 & 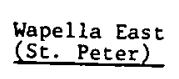 & $\begin{array}{l}\text { Media } \\
\text { (Galesvil1e) }\end{array}$ & $\begin{array}{l}\begin{array}{c}\text { Parnel1 } \\
(\text { St. Peter })\end{array} \\
\end{array}$ & 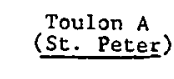 & 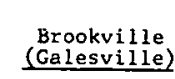 & $\begin{array}{l}\text { Fishhook } \\
\text { St. Peter) }\end{array}$ & \multirow[t]{5}{*}{ 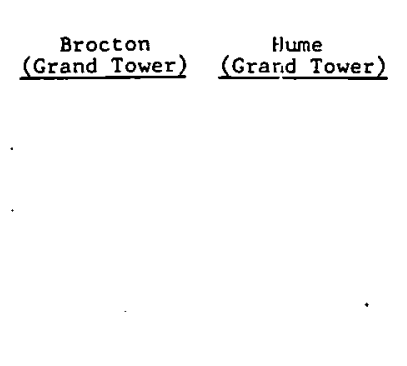 } \\
\hline & Description & & & & & & & & \\
\hline & Structures and Improvements (Cont' $d$ ) & & & & & & & & \\
\hline $\begin{array}{l}: 21 \\
: 2101 \\
: 2102\end{array}$ & 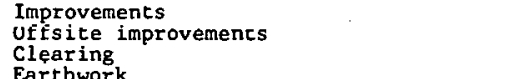 & $\$ 15,000$ & $\$ 80,000$ & $.945,000$ & $\$ 50,000$ & $\$ 100,00 c$ & $\$ 95,000$ & $\$ 80,000$ & \\
\hline \multirow{2}{*}{$\begin{array}{l}.210202 \\
.21021 \\
.21022 \\
.21023 \\
.21023 \\
.21024\end{array}$} & 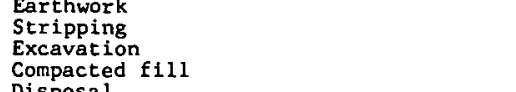 & $\begin{array}{l}20,000 \\
65,000 \\
35,000\end{array}$ & $\begin{array}{l}145,000 \\
2555,000 \\
2250\end{array}$ & $\begin{array}{l}70,000 \\
419 ;, 000 \\
39000\end{array}$ & $\begin{array}{l}199,000 \\
1550,000 \\
1500\end{array}$ & 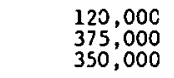 & $\begin{array}{l}140,000 \\
950,000 \\
440,000\end{array}$ & $\begin{array}{l}\substack{110 \\
375,000 \\
35,0000} \\
3,000\end{array}$ & \\
\hline & TOTAL 311.2102 & $\$ 120,000$ & $\$ 67,000$ & $\$ 875,000$ & $\$ 415,000$ & $\$ 845,000$ & $\frac{140,000}{\$ 1,670,000}$ & $\$ 840,000$ & \\
\hline \multirow{3}{*}{$\begin{array}{l}.2103 \\
.21031 \\
.212033 \\
.21035 \\
.21036 \\
.21037\end{array}$} & 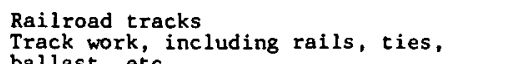 & 165,000 & $1,445,000$ & 815,000 & 290,000 & 1,795,000 & $1,365,000$ & $1,300,000$ & \\
\hline & 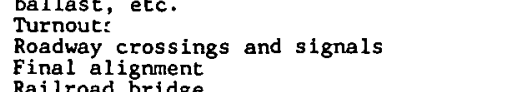 & $\begin{array}{l}\begin{array}{l}30,000 \\
5,000 \\
5,000\end{array} \\
5\end{array}$ & $\begin{array}{l}\substack{45,000 \\
25,000 \\
45,000} \\
4\end{array}$ & $\begin{array}{l}45,000 \\
45,000 \\
45000\end{array}$ & $\begin{array}{l}45,000 \\
40,000 \\
10,000\end{array}$ & $\begin{array}{l}\substack{45,000 \\
\text { s5, } \\
55,000} \\
0\end{array}$ & $\begin{array}{l}\begin{array}{l}45,000 \\
40,000 \\
45,000\end{array} \\
0\end{array}$ & 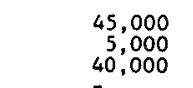 & \\
\hline & TOTAL 311.2103 & $\$ 205,000$ & $\$ 1,560,000$ & $\$ 925,000$ & $\$ 385,000$ & $\$ 1,915,000$ & $\$ 1,495,000$ & $\$ 1,390,000$ & \\
\hline \multirow{3}{*}{$\begin{array}{l}\text { - } 21044 \\
: 21041 \\
: 21042 \\
: 21043\end{array}$} & $\begin{array}{l}\text { Roads } \\
\text { Ugprade existing roads }\end{array}$ & & 825,000 & 70,000 & & & & 400,000 & —See Note 6 on Page $c$ \\
\hline & $\begin{array}{l}\text { Oetep passes, inciuding temporary by-pass } \\
\text { Access roads }\end{array}$ & $i 5,000$ & 5,000 & $\begin{array}{l}40,000 \\
40,000\end{array}$ & 30,000 & 70,000 & $\begin{array}{l}500,000 \\
0.0500\end{array}$ & 105,000 & \\
\hline & TOTAL 311.2104 & $\$ 15,000$ & $\$ 830,000$ & $\$ 120,000$ & $\$ 30,000$ & $\$ 70,000$ & $\$ 605,000$ & $\$ 505,000$ & \\
\hline \multirow{5}{*}{$\begin{array}{l}.2105 \\
.2106 \\
.215 \\
.2151 \\
.2152 \\
.2152\end{array}$} & 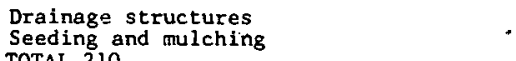 & $\begin{array}{r}10,0,00 \\
5,000 \\
0.00\end{array}$ & $\begin{aligned} 5,000 \\
5\end{aligned}$ & $\begin{array}{l}{ }_{20}^{140,000} \\
20,000 \\
\end{array}$ & $\begin{array}{r}170,000 \\
5,000\end{array}$ & $\begin{array}{l}95,000 \\
80,000\end{array}$ & 25,000 & $\begin{array}{r}75,000 \\
40,000 \\
\end{array}$ & \\
\hline & 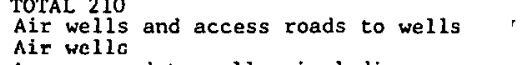 & 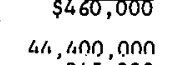 & 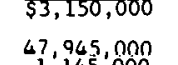 & 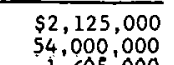 & $\begin{array}{l}\$ 1,055,000 \\
56,260,000\end{array}$ & $\begin{array}{l}\frac{53,105,000}{139,575000} \\
149,5\end{array}$ & $\$ 3,890,000$ & $\begin{array}{l}\begin{array}{l}22,930,0,000 \\
164,000,000\end{array} \\
\end{array}$ & \\
\hline & $\begin{array}{l}\text { Aacess coadd to wel1s, includim } \\
\text { earrthork }\end{array}$ & , 945,000 & $\begin{array}{ll}-1,145,000 \\
1,140\end{array}$ & $1,605,000$ & $1,450,000$ & $\begin{array}{l}3,965,000 \\
3,960\end{array}$ & $\begin{array}{ll}13,4,005,000 \\
4,900\end{array}$ & $\begin{array}{l}3,313,000 \\
3,1300\end{array}$ & \\
\hline & TOTAL 311.215 & $\$ 45,345,000$ & $\$ 49,090,000$ & $\$ 55,605,000 \$$ & $\$ 57,710,000, \$$ & $\$ 153,540,000$ & $\$ 137,105,000$ & $\$ 169,315,000$ & \\
\hline & TOTAL 311.21 & $\$ 45,805,000$ & $\$ 52,240,000$ & $\$ 57,730,000$ & $558,765,000$ & $56,645, \cap 00$ & $\$ 140.995,000$ & $\$, 172,245,000$ & \\
\hline
\end{tabular}




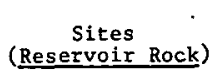
Description

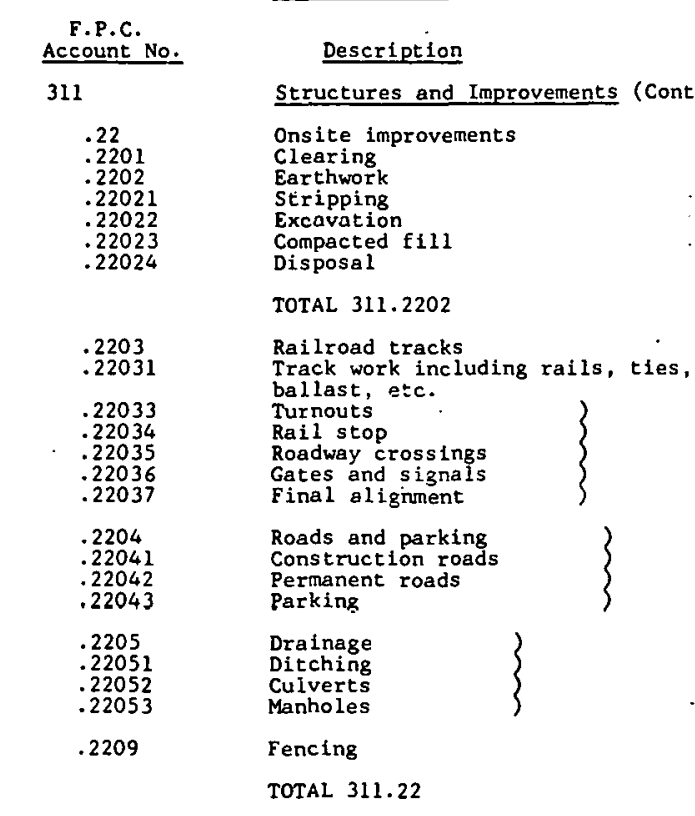

TOTAL 311.22

TOTAL 311.2

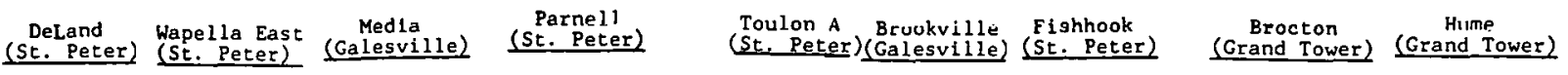

\begin{tabular}{|c|c|c|c|c|c|c|}
\hline$\$ 300,000$ & $\$ 300,000$ & $\{300,000$ & $\$ 300,000$ & $\$ \$ 00,000$ & $\$ 300,000$ & $\$ 300,000$ \\
\hline $\begin{array}{l}410,000 \\
4455,000 \\
485,000\end{array}$ & $\begin{array}{l}430,000 \\
335,000 \\
385,000\end{array}$ & $\begin{array}{r}410,000 \\
80,000 \\
1,010,000\end{array}$ & 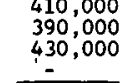 & 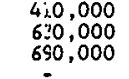 & $\begin{array}{l}4,110,000 \\
1,70000000 \\
1,900,000\end{array}$ & 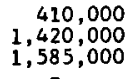 \\
\hline & & & & & & \\
\hline
\end{tabular}

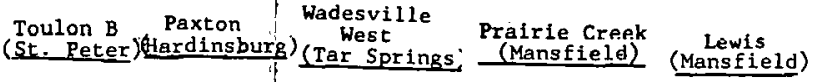

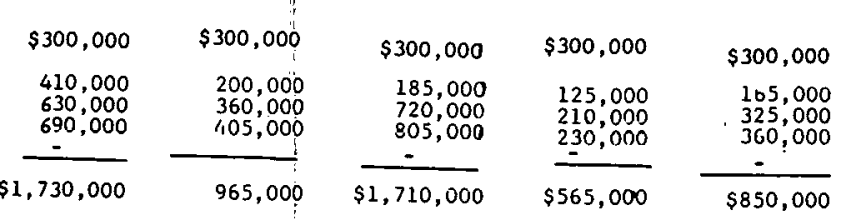

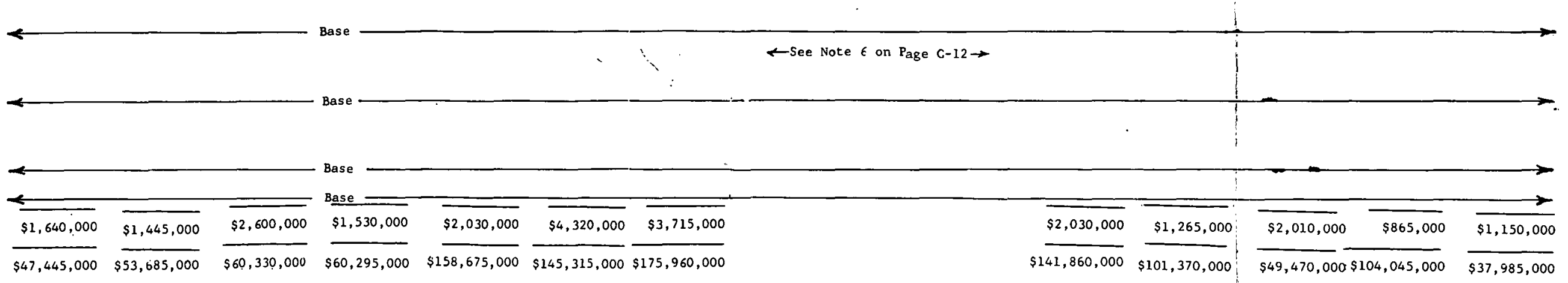




\begin{tabular}{|c|c|c|c|c|c|c|c|c|c|}
\hline & (Reservoir Rock) & 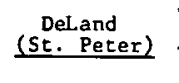 & 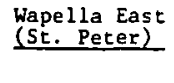 & 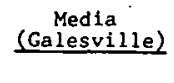 & 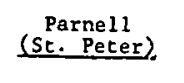 & 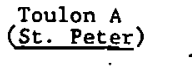 & $\begin{array}{l}\text { Brookville } \\
\text { (calesvillee }\end{array}$ & 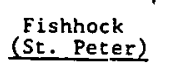 & $\begin{array}{l}\text { (Goccon } \\
\text { Grand Tower) (Grand Tower) }\end{array}$ \\
\hline 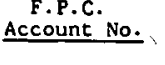 & Description & & & & & & & & \\
\hline $\begin{array}{l}311 \\
.42\end{array}$ & $\begin{array}{l}\text { Structures and Improvements (Cont'd) } \\
\text { Screen house at reservoir }\end{array}$ & & & $\begin{array}{c}5155,000 \\
0\end{array}$ & & $-5880,000$ & $\$ 145,000$ & $\{1770.000$ & \\
\hline & TUTAL 3HL & $\$ 55,955,000$ & $\$ 59,840,000$ & $\$ \in 2,545,000$ & $\$ 67,025,000$ & $\$ 164,895,000$ & $\$ 147,665,000$ & $\$ 1,79,510,000$ & \\
\hline 314 & Turbine Plant & & & & & & & & \\
\hline $\begin{array}{l}: 1 \\
: 11 \\
: 12 \\
: 13\end{array}$ & 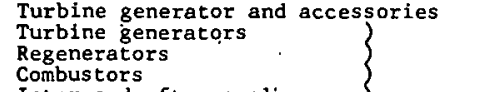 & $170,500,000$ & $174,900,000$ & $172,700,000$ & $176,000: 00 \mathrm{c}$ & $169 ; 400,000$ & $196,900,000$ & $185,900,000$ & \\
\hline $\begin{array}{l}: 21 \\
: 21 \\
: 212 \\
: 213 \\
: 214\end{array}$ & 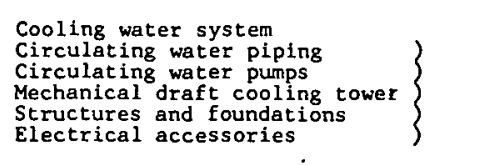 & $22,200,000$ & $22,200,000$ & $22,200,000$ & $: 2,200,000$ & $22,200,000$ & $22,200,000$ & $22,200,000$ & ऍee Note 6 on Page $\mathrm{C}-12 \longrightarrow$ \\
\hline$: 221$ & $\begin{array}{l}\text { Compressed air piping } \\
\text { Piping, fittings, and valves }\end{array}$ & . 18, 653,000 & $.22,539,000$ & $28,336,000$ & $25,326,000$ & $149,483,000$ & 236,238 , ח00 & $210,564,000$ & \\
\hline $\begin{array}{l}.231 \\
.2323 \\
.233\end{array}$ & 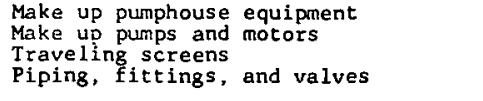 & $\begin{aligned} \begin{array}{r}152,4000 \\
32,000 \\
12,16,7,000\end{array} & \end{aligned}$ & $\begin{array}{r}\begin{array}{r}179,000 \\
34,000 \\
12.762,000\end{array} \\
\end{array}$ & $\begin{array}{l}\begin{array}{l}267 \\
110,000 \\
14,819 ; 000\end{array} \\
14,000\end{array}$ & $\begin{aligned} \begin{array}{r}242,000 \\
34,000\end{array} \\
27,233^{3}, 000\end{aligned}$ & $\begin{array}{r}180,000 \\
12,687,000\end{array}$ & 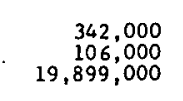 & $\begin{array}{rl}3 & 355,000 \\
1123 & 0.000 \\
21,608.0000\end{array}$ & \\
\hline $\begin{array}{l}.24 \\
.241 \\
.242\end{array}$ & 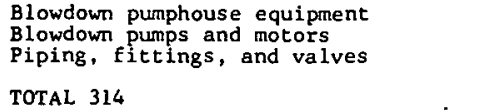 & $\frac{182,000}{\$ 23,888,000}$ & $\frac{1,319,000}{\$ 240,040,0009}$ & $\begin{array}{l}7,284,000 \\
245,818,000\end{array}$ & $\frac{16,743,000}{\$ 267,000}$ & $\frac{4,62,000}{\$ 358,339,000}$ & $\frac{9,1757,000}{\$ 485,559,000}$ & $\begin{array}{l}\frac{104,000}{10,011,000} \\
\$ 451,505,000\end{array}$ & \\
\hline
\end{tabular}




\begin{tabular}{|c|c|c|c|c|c|c|c|c|c|c|c|c|c|c|}
\hline \multirow{3}{*}{ 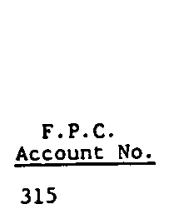 } & \multirow{3}{*}{$\begin{array}{l}\text { (Bites } \\
\text { (Reservoir Rock) } \\
\text { Description }\end{array}$} & $\begin{array}{l}\text { DeLand } \\
\text { (st. Peter) }\end{array}$ & $\begin{array}{l}\text { Japella East } \\
\text { (St. Peter) }\end{array}$ & $\begin{array}{l}\text { Media } \\
\text { Gealesvil1e2 } \\
\end{array}$ & \multicolumn{2}{|c|}{ 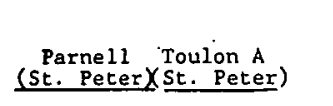 } & 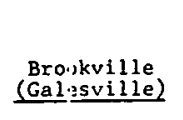 & 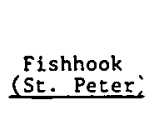 & $\begin{array}{c}\text { Brocton } \\
\text { (Grand Tower) }) \text { (Grand Tower) }\end{array}$ & \multicolumn{2}{|c|}{$\begin{array}{l}\text { Toulon B B Paxton } \\
\text { (St. Peeter) Adardinsbur. }\end{array}$} & \multicolumn{2}{|c|}{ 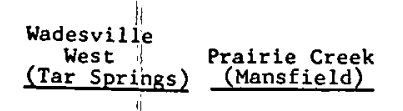 } & \multirow[t]{2}{*}{ (Manjfis } \\
\hline & & & & & & & & & & & & & & \\
\hline & & & & & & & & & & & & & & \\
\hline .1 & 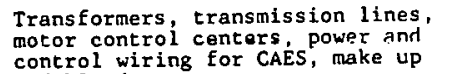 & & & & & & & & & & & & & \\
\hline .11 & 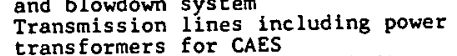 & - $\$ 2,694,000$ & $\$ 2,706,000$ & $\$ 2,732,000$ & $\$ 2,866,000$ & $\$ 3,379,00 c$ & $\$ 3,430,000$ & $\$ 3,442,000$ & & $\$ 2,979,000$ & $\$ 2,565,000$ & $\$ 1,409,000$ & $\$ 1,539,000$ & $\$ 673,000$ \\
\hline .12 & 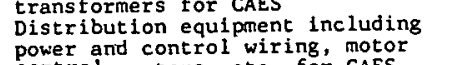 & 621,000 & 713,000 & 885,000 & 948,000 & $3,639,000$ & $4,641,000$ & $4,455,000$ & & $3,176,000$ & $2,643,000$ & 615,000 & $3,431,000$ & $1,407,000$ \\
\hline .13 & 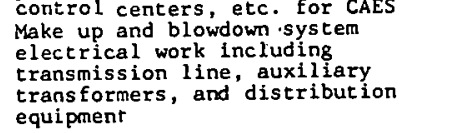 & 454,000 & 495,000 & 542,000 & 815,000 & $485,000^{\circ}-$ & 689,000 & 731,000 & & 393,000 & 472,000 & 689;000 & 281,000 & 700,000 \\
\hline & TOTAL 315.1 & $\$ 3,769,000$ & $\$ 3,914,000$. & . $\$ 4,159,000$ & $\$ 4,629,000$ & $\$,, 503,000$ & $\$ 8,760,000$ & $\$ 8,628,000$ & - See Note 6 on Page $\mathrm{C}-12 \rightarrow$ & $\$ 6,548,000$ & $\$ 5,680,000$ & $\$ 2,713 ; 000$ & $\$ 5,251,000$ & $\$ 2,780,000$ \\
\hline \multirow[t]{4}{*}{$:_{3}^{2}$} & $\begin{array}{l}\text { Transmission lines to network } \\
\text { Switchyard } \\
\text { Bat ance of plant electrical }\end{array}$ & $212,271,000$ & $14,359,000$ & 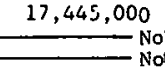 & $\begin{array}{l}12,442,000 \\
\text { Included } \\
\text { Incl luded d }\end{array}=$ & $22,929,000$ & $7,660,000$ & $1,650,000$ & & & $4,522,000$ & & $6,860,000$ & $\stackrel{6,860,000}{\longrightarrow}$ \\
\hline & $\begin{array}{l}\text { equipment } \\
\text { TOTAL } 31.5\end{array}$ & $\$ 16,040,000$ & $\$ 18,273,000$ & $\$ 21,604,000$ & $\$ 17,071,000$ & $\$ 30,432,000$ & $\$ 16,400,000$ & $\$ 10,278,000$ & & $\$ 26,305,000$ & $\$ 10,202,000$ & $\$ 8,043,000$ & $\$ 12,111,000$ & $\$ 9,640,000$ \\
\hline & TOTAL ESTTMATED CONSTRUCTION COST & $\$ 315,023,000$ & $\overline{\$ \$ 334,148,000 \mathrm{~s}}$ & $\$ 340,047,000$ & $\$ 373,692,000$ & $5571,001,000 ?$ & $\$ 663,759,000$ & $\$ 665,298,000$ & & $\$ 444,988,00 n$ & $\$ 4044,089,0000$ & $\$ 167,900,000$ & $\$ 353,688,000\}$ & $8170,149,000$ \\
\hline & DOLLARS PER KILOWATT & $\$ 315.00$ & $\$ 334.10$ & $\$ \$ 340.00$ & $\$ 373.70$ & $\$ 571.60$ & $\$ 6,3.80$ & $\$ 665.30$ & & $\$ 574,20$ & $\$ 583.10$ & $\$ 513.50$ & $\$ 1,437.80$ & $\$ 1,736.20$ \\
\hline
\end{tabular}


Nores:
1. Cost for land acquisition for plant site and reservoir were based on an average of $\$ 3,000.00$ per acre; costs for storage rights
accuisition were based on an average of $\$ 300.00$ per acre.

2. We11 pricing was based on Katz and Lady "Compressed Air Storage" 1976 Report and escalated to March 1979 prices.

3. The following costs are not included i.l the above estimate

a. Indirect expenses.

b. Escalation of equipnent, materials, erectivin and construction labor.

fuction (AFDC).

d. Sales and use taxes.

Deteral and electrical facilities for the main power block.

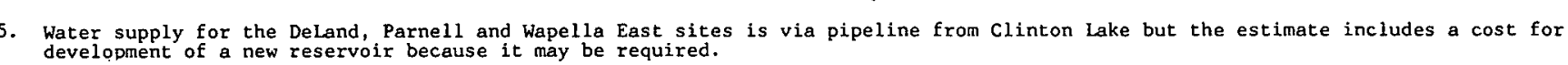

6. The coste estinates for Brocton and Hune are not included due to the large number of wells calculated based on the
extremely y low values of aquifer permability and discovery pressure in published information. 


\section{CAES-T2}

Attachment D

POTENTIAL AREAS OF RISK FROM CAES AQUIFER PLANT

\section{CONTENTS}

Section

Page

D. I GENERAL

D. 2 DISCUSSION

D.2.1 Formation of Explosive Mixtures

D.2.2 Potential Leakage from Air Storage Reservoir

D.2.3 Chemical and Biological Contamination of Potable Aquifer

D.2.4 Alteration of Groundwater Flow Patterns

$D-1$

$\mathrm{D}-1$

D-1

$D-3$

$\mathrm{D}-4$

$D-5$

D.2.5 Potential Crop Damage

$D-5$

D.2.6 Surface and Groundwater Contamination from

$D-5$ Pumping Test

REFERENCES

$D-6$ 


\section{CAES-T2}

Attachment D

POTENTIAL AREAS OF RISK FROM CAES AQUIFER PLANT

\section{I GENERAL}

The main areas of potential risk to the project include the following: formation of explosive mixtures at a later date if gas is stored in a reservoir previously used for the air testing program; potential leakage from the air storage reservoir; chemical and biological contamination of a potabie aquifer; alteration of groundwater flow patterns; potential crop damage from air leakage; and surface and groundwater contamination from the pumping test.

\section{2 DISCUSSION}

\section{D.2.1 Formation of Explosive Mixtures}

One potential source of risk could occur if a gas. storage company were to utilize a reservoir for natural gas |storage after the air injection test program. P. A. Witherspoon (1) felt that risk would rest with the gas companies, as all work being performed as part of the CAES program will be public record. He also felt that gas storage companies would shy away from a field that had been previously used for air storage. There would always be pockets of air in the reservoir, and these pockets could form a combustible mixture when mixed with natural gas. However, if the storage company kept the air-gas mixture coming from the reservoir from further mixing with air in lines there would probably be no danger of explosions. 
D. L. Katz (2) felt that an air storage reservoir could be safely converted to natural gas storage. There probably would be added expenses, for an air sweep and added precautions for monitoring operations.

An investigation of the available literature revealed several papers that point out the danger of explosions when air is used to repressure oil fields. Ryder (3) states that any air-gas mixture in the casing head is potentially explosive if the quantity of air is more than $80 \%$ air to $20 \%$ gas and that it is best to keep the air content below $60 \%$. Dickey and Bossler (4) referred to explosion problems in the Venango Field, Pennsylvania. On the other hand, Russian workers have reported no adverse effects from the injection of natural gas into aquifers previously tested with injected $\operatorname{air}(\underline{5})$.

A major concern with testing a site with air is that gas storage companies would probably not use a structure for gas storage that had been tested with compressed air. This effectively removes a potential gas storage site from future development. A landowner who has allowed air injection into a geologic structure beneath his property faces the possibility of a future loss of income due to modifications in the storage reservoir. 


\section{D.2.2 Potential Leakage from Air Storage Reservoir}

A major source of risk could occur as a result of air

leaking from the air reservoir reaching the ground surface or a potable aquifer. The major problem is not necessarily in the leakage of air, but the mixing of air with natural gas during its passage through higher strata. There have been cases in the gas storage industry where gas has leaked into farm wells and exploded. Also, there are cases where the gas storage companies have had to replace wells or provide farmers with potable water due to gas contarnination of existing water wells. An example of this situation occurred at the Herscher Project in eastern Illinois (see Reference $\underline{6}$ for a description of the project). In order to protect the project from unwarranted claims, P. A. Witherspoon (l) recommends taking water samples of all farm and municipal wells within 1 mile of the spillpoint contour. These samples should be tested before the injection of air by an independent laboratory for mineral content, coliform bacteria, nitrates, and minute gas content (particularly methane and ethane). The test results should be returned to the well owner by registered letter. Also, a waterlevel recorder should be installed in a water well that represents the type of completion for the wells in the site area. The procedure adds another method of checking for any leakage through the caprocks. 
It should be noted that each site has to be examined individually for potential air leakage concerns. Some sites do not have any strata above the storage zone that contain natural gas or hydrocarbons, while some sites in central Illinois and Indiana have natural gas. The bedrock aquifers at the contral Ilinols sites are saline and are not utilized as a source of groundwater; however, in northern and western Illinois almost all of the aquifers contain potable water.

To ensure that an air storage reservoir site has capable caprock and to protect the project from unwarranted claims, certain tests should be performed. ilhese include a thorough geologic investigation, laboratory tests for caprock threshold pressure and an aquifer pumping test. Evaluation of the pumping test will immediately indicatc any large lcaks, such as undisclosed faulting. However, subtle leaks may be difficult to determine, and may require a number of observation wells.

\section{D.2.3 Chemical and Biological Contamination of Potable Aquifer} Another potential concern and source of risk is from air leakage carrying chemical or geological contamination, introduced during the drilling operations, from the air storage reservoir into a stratigraphically higher aquifer containing potable water. All known aquifers above the storage reservoirs should be tested for mineral content, coliform bacteria, and minute gas quantities before beginning the air injection test program. 


\section{D.2.4 Alteration of Groundwater Flow Patterns}

Air leakage could also accumulate in stratigraphically higher aquifers and displace the water, therefore altering flow patterns and disrupting water supplies ( 7 ). If the air storage reservoir is in a potable aquifer, a potential problem could arise if the air leaks past the spillpoint to a portion of the aquifer presently being utilized for potable.water supplies. To monitor potential air leakage into higher aquifers or laterally past the spillpoint, it is important to have ouservation wells in porous zones above the storage zone and at the spillpoints.

\section{D.2.5. Potential Crop Damage}

Loss of crops due to leaking air is a potential source of Iiability. Katz and Lady ( 18 ) have indicated that when natural gas leaks to the ground surface, vegetation is stuntied or kilied. Such a reaction to has been noted over gas storage fields when leaks were known to be occurring. Katz and Lady. (8) feel the harm to vegetation is likely to be the same for percolating air as for gas. The reason is that percolating gas is believed to interfere with the capiliary behavoir of the soil-water system so that it cannot support normal vegetation.

\section{D.2.6 Surface and Groundwater Contamination from Pumping Test}

Contamination of surface waters and potable groundwater by brines produced during the pumping test is a possible 
concern. To protect against such contamination, the waste holding pond will be constructed to meet all applicable state and federal standards for waste storage ponds. Deponding on local soil conditions present at the site, it may be necessary to have a few observation wells to monitor for potential brine leakage: It should be noted that the storage reservoirs have a wide variance in water quality, some even contain potable water. Water samples should be taken from the air storage reservoir. for laboratory tests on mineral content and total dissolved solids. These data can be utilized to evaluate the seriousness of any potential leakage from the water holding pond. Potential contamination problems resulting from a water pumping test may be eliminated by lining the holding pond. However, the construction of a pond lining depends on individual site conditions and local environmental regulations, and these constraints vary throughout the United States.

Another potential area of risk from the pumping test is contamination of agricultural soils causing loss of farmland. In this case, it may be necessary to either compensate the farmer for loss of farmland or to remove the contaminated soil and replace it with tillable soil.

\section{REFERENCES}

1. P. A. Witherspoon, Geologic Consultant. Personal Communication on August 8, 1979, at meeting at Sargent \& Lundy, Chicago, Illinois. 
2. D. I. Katz, Reservoir Consultant. Letter of August 13, 1979, to D. L. Mussa, Senior Structural Project Engineer, Sargent \& Lundy, Chicago, Illinois.

3. H. M. Ryder. "Pressuring Efficiency." Producers Monthly, Vol. 1, No. 12 (Oct.), 1937, pp. 6-11.

4. P.A. Dickey and R. B. Bossler. "Venango Fields of Pennsylvania." Producers Monthly, Vol. 5, November 1940 , pp. 9-21.

5. Economic Commission for Europe Committee on Gas. "The Theoretical and Economic Aspects of the Storage of Gas in Water-Bearing Beds Situated in Horizontal or Slightly Sloping Strata." Report received from the USSR: Economic Commission Europe, Committee on Gas; Working Party on the Transmission of Gas (lst session), Gas/ WP.5/Working Paper No. 3, April 27, 1966. English (orig. Russian).

6. T. C. Buschbach and D. C. Bond. "Underground Storage of Natural Gas in Illinois." Illinois Petroleum, No. 101. Urbana, Illinois: Illinois State Geological Survey, 1974.

7. J. A. Stottlemyre and W. V. Loscutoff. "Environmental Concerns for Compressed Air Energy Storage in Porous Media Systems." In Proceedings of the 1978 Compressed Air Energy Symposium, pp. 667-686. Pacific Grove, California: Department of Energy, 1979. CONF-780599.

8. D. L. Katz and E. R. Lady. Compressed Air Storage. Ann Arbor, Michigan: Ulrich's Books, Inc., 1976. page 181 . 
B 


\author{
Appendix B \\ REEVALUATION OF PAXTON SITE FOR \\ COMPRESSED AIR ENERGY STORAGE \\ CONTENTS
}

Section

REFERENCES
Page

B-2 


\section{Appendix B}

\section{REEVALUATION OF PAXTON SITE FOR COMPRESSED AIR ENERGY STORAGE \\ TABLES}

\section{Table}

$B-1$

Cumulative Pore volume at the Paxton site. 


\begin{abstract}
Appendix B
REEVALUATION OF PAXTON SITE FOR

COMPRESSED AIR ENERGY STORAGE
\end{abstract}

ILLUSTRATIONS

Figure

Page

$\mathrm{B}-1$

Structure Contour Map for the

$\mathrm{B}-3$

Paxton Site Based on New IGS

Well

B-i i 
Appendix B

REEVALUATION OF PAXTON SITE FOR

COMPRESSED AIR ENERGY STORAGE

The Indiana Geological Survey (IGS) decided to test the basic premise for the Paxton site by drilling a test well with its own rig during the summer of 1979 (1). Based on two wells located in the southwest corner of Section 28 of Township 7 North and Range 9 West, a Mississippian Hardinsburg erosional remnant capped by Mississippian Glen Dean limestone was postulated when drilling began. It was anticipated that both the Glen Dean and Hardinsburg were nearly flat structurally, thus the Glen Dean was expected at a depth of between 880 and 890 feet. The Hardinsburg Sandstone was expected at a depth of 930 feet below the surface.

The location of the new well is approximately 75.0 feet west of the corner of sections $21,22,27$, and 28 and is shown on Figure B-1 (a modification of Figure 4-34 from Appendix A). Drilling was stopped at a depth of 950 feet without encountering either Glen Dean or Hardinsburg rocks. Since Pennsylvanian rocks were still present at the total depth, it was felt that the erosional remnant does not exist at this location (1). This interpretation indicates that the Hardinsburg storage reservoir at the Paxton site could be no greater than one-third the original postulated size and may even be considerably smaller, although additional drilling would be needed to fully evaluate the site. 
The results of the IGS test well give a calculated potential capacity for the reservoir of $1.68 \times 10^{9}$ cubic feet, which is insufficient to support a compressed air energy storage plant of greater than $100 \mathrm{MW}$. The actual capacity, furthermore, may even be less. The new information gives a calculated pore volume of $0.11 \times 10^{9}$ cubic feet and an areal extent of 330 acres for the erosional Hardinsburg Formation remnant. The revised values for the pore volume at the Paxton site are listed in Table $B-1$.

\section{REFERENCES}

I: B. D. Keith, Geologist, Pctrolcum section, Indiana Geological Survey, Bloomington, Indiana. Letter of January 14, 1980, to J. M. Bumgarner, Project Engineer, Public Service Company of Indiana, Inc., Plainfield, Indiana.

2. B. D. Keith, Geologist, Petroleum Section, Indiaria Geological Survey, Bloomington, Indiana. Transmittal on February 19, 1978, of Structure Contour Maps to A. K. Yonk, Senior Geologist, Sargent \& Lundy, Chicago, Illinois. 


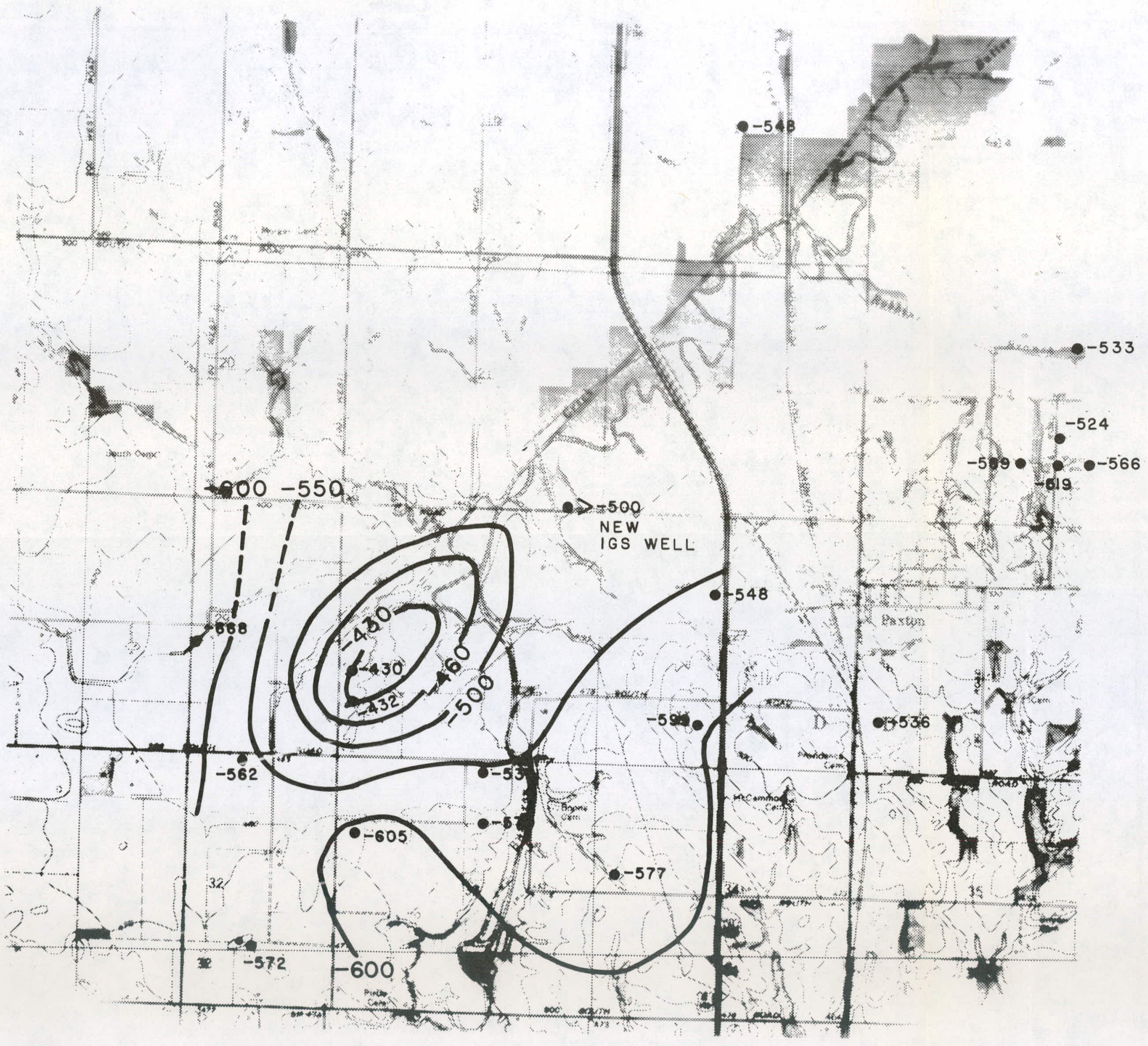

- -570 APPROXIMATE WELL LOCATION AND ELEVATION (MSL) OF THE BASE OF THE PENNSYLVANIAN.

=500 - STRUCTURE CONTOUR AND ELEVATION (MSL) OF THE BASE OF THE PENNSYLVANIAN.

\section{NOTES}

BASE MAP FROM 7.5 MINUTE SULLIVAN QUADRANGLE, INDIANA, 1941-56.

2. STRUCTURE CONTOURS FROM B.KEITH $(\underline{1}, \underline{\underline{2}})$ 。

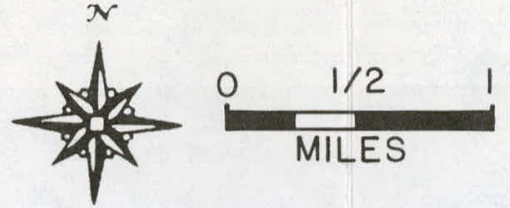

STRUCTURE CONTOUR MAP FOR THE PAXTON SITE BASED ON

SARGENT\&LUNDY 


\section{THIS PAGE}

\section{WAS INTENTIONALLY \\ LEFT BLANK}


TABLE B-1

CUMULATIVE PORE VOLUME AT THE PAXTON SITE

$\begin{array}{ccc}\begin{array}{c}\text { CONTOUR } \\ \text { (feet MSL) }\end{array} & \text { AREA (acres) } & \begin{array}{c}\text { CUMULATIVE } \\ \text { PORE VOLUMEa } \\ \text { (cubic feet) }\end{array} \\ -428 \text { (peak) } & 0 & - \\ -430 & 52 & 430,373 \\ -460 & 173 & 28,363,223 \\ -500 \text { (maximum } & 330 & 111,600,000 \\ \text { spillpoint) } & & \end{array}$

apore volumes were calculated using the following formula: pore volume in cubic feet $=\frac{h}{2} \times\left(A_{1}+A_{2}\right) \times 43,560 \times$ porosity

where $h=$ height based on difference in contour intervals (feet)

$\mathrm{A}_{1}=$ area within upper contour (acres):

$A_{2}=$ area within lower contour (acres)

$43,560=$ number of square feet in an acre

porosity $=19.0 \%$ for the reservoir rock, which is Hardinsburg Sandstone 


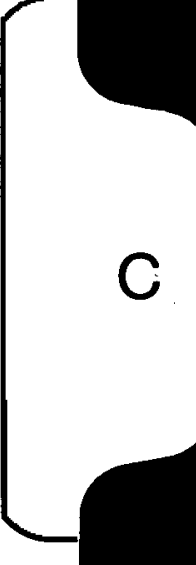




\author{
Appendix C \\ COMPRESSED AIR ENERGY \\ STORAGE DRILLING AND TESTING \\ GENERIC SPECIFICATION
}

$C-i$ 


\section{COMPRES̃SED ALK ENERGY STORAGE}

DRI LLING AND TESTING

GENERIC SPECIFICATION

\section{TABLE OF CONTENTS}

\section{ARTICLE}

\section{DIVISION 1 - GENERAL REQUIREMENTS}

101. Purchaser............................. $1-1$

102. Name of Project............................ 1-1

103. Location of Project........................ 1 .1

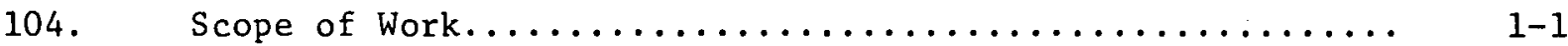

105. Schedule of Work........................... 1-5

106. Permits..............................

107. Definitions............................. 1-6

108. Site Conditions.......................... 1-6

109. Protection.............................. $1-7$

110. Maintenance of Existing Roads................... 1-8

111. Lines and Grades.......................... 1-8

112. Codes, Standards and Referenced Publications........... 1-8

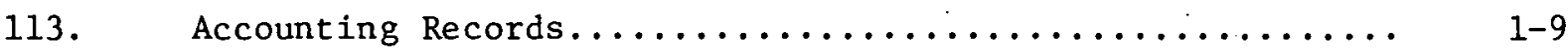

DIVISION 2 - STANDARD AND DRAWINGS

201. Design Drawings (Consulting Engineers') $\ldots \ldots \ldots \ldots \ldots \ldots \ldots$........

202. Data (Contractor's) ......................... 2-1

203. Driller's Field Records...................... 2-1

204. Soil Driller's Records...................... 2-2

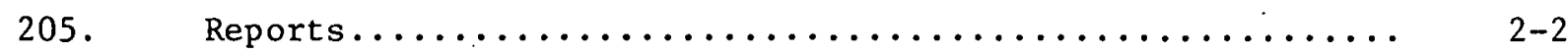

206. Packing and Shipping Samples.................. 2-2 
TABLE OF CONTENTS, Cont.

ARTICLE

PAGE

DIVISION 3 - SLIMHOLE STRUCTURE TEST WELLS

301. Genera1............................. 3-1

302. Equipment and Materials.................. $3-1$

303. Construction of Wel1s...................... 3-1

304. Drill Cuttings Samples.................... 3-2

305. Plugging of Wells...................... $3-2$

306. Removal of Mud Pit.......................... $3-3$

DIVISION 4 - INJECTION/WITHDRAWAL WELLS ANDD OBSERVATION WELLS

401. General................................. $4-1$

402. Equipment and Materials................... 4-1

40J. Construction of Injection/Withdrawal Wells.......... 4-2

404. Construction of Reservoir Wells................ 4-4

405. Construction of Caprock Observation Well........... 4-5

406. Alignment and Plumbness.................... 4-6

407. Well Perforating........................ 4-7

408. Core Analyses......................... 4-7

409. Water Testing........................... 4.4

410. Sampling and Drilling Time.................. 4-8

DIVISION 5 - CONSTRUCTION OF WATER HOLDING POND

501. Drilling and Sampling.................... $5-1$

502. Laboratory Tests....................... $5-2$

503. Percolation Tests........................ $5-2$

504. Earthwork........................... $5-3$

505. Slope Protection........................ $5-4$ 
TABLE OF CONTENTS, Cont.

\section{ARTICLE}

DIVISION 5 - CONSTRUCTION OF WATER HOLDING POND, Cont.

506

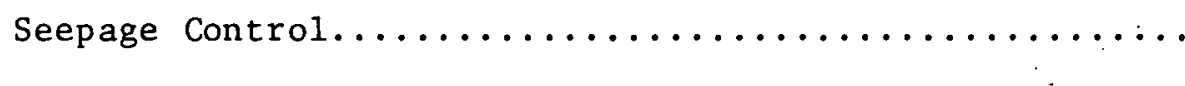

$5-5$

507.

Demolition Work..

$5-5$

DIVISION 6 - WATER PUMPING TEST

601.

6-1

602. Materials and Equipment........................ $6-1$

603. Execution............................ $6-1$

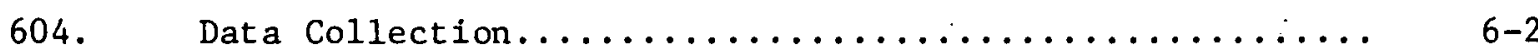




\section{THIS PAGE \\ WAS INTENTIONALLY \\ LEFT BLANK}

$T C-4$ 
SPECIFICATION FOR

COMPRESSED AIR ENERGY STORAGE

DRILLING AND TESTING

DIVISION 1 - GENERAL REQUIREMENTS

101. PURCHASER:

102. NAME OF PROJECT:

103. LOCATION OF PROJECT

104. SCOPE OF WORK

104.1 Contractor sha11 perform the following WORK for and at the above Project Site :

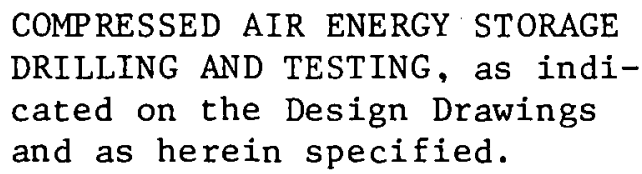

104.2 Work Furnished and Installed or Performed: Contractor shall furnish, install and/or perform materials, equipment and services to complete the WORK as subdivided hereinafter with respect to the varfous phases of the WORK:

a. Phase I - Slimhole Structure Test Wells:

a1. Survey we11 locations

a2. Drill and geologically log wells

a3. Geophysically log wells (electric-induction)

a4. Construct mud pits

a5. Plug wells to within 3 feet of ground surface

a6. Backfill mud pits and restore area to original condition

a7. Progress reports, and field and laboratory test data

b. Phase II - Injection-Withdrawal We11s and Observation We11s:

bl. Survey well locations

b2. Dri.l1 wells into bedrock, install surface casing and casing head hous-ing

b3. Complete drilling of wells to total depth, retrieve rock cores, package and ship samples to testing laboratory 
b4. Run borehole geophysical logs (Compensated Neutron and Formation Density Log)

b5. Install long string casing

b6. Run 3-D cement bond logs in wellis

b7. Perforate casing

b8. Cap wells upon completion of WORK

b9. Phone daily progress and submit weekly progress reports, and field and laboratory test daca

c. Phase III - Construction of Water Holding Pond

d. Phase IV - Water Pumping Test:

dl. Furnish and install Reda*pump, control panel and metering devices for the highest crest well, including the following:

d1.1 Water leve1 recorders in observation wells

UL.2 Aluustic water level findera in pumping will

d1. 3 Recording barograph

d2. Perform test on crest we11, including the following:

d2.1 Monitor pumping rate and draw-down or pumping level

d2.2 Obtain and analyze water samples.

d2. 3 Reinject filtered water from holding pond back into one of the observation wells.

d3. Remove holding pond and restore area to original condition

d4. Submit daily and weekly progress reports, and field and laboratory test data

e. All other work specified herein or as directed by Project Manager/ Purchaser to properly complete the WORK

104.3 Special Provisions: The WORK shall also conform to the following special provisions :

a. Work on Private Property: Contractor shall not enter up on or allow any of his employees to enter upon any private property without prior authorization from Purchaser to do so.

b. During the course of the WORK, Contractor shall immediately report to Purchaser any unusual conditions which may affect the progress of the WORK.

*This equipment or its equal will be selected for the actual specification. 
c. Contractor is advised that if during the prosecution of the WORK, downtime occurs due to mechanical failure of Contractor's equipment, or due to inclement weather, Purchaser will not reimburse Contractor for such delays.

d. Consulting Geologists: Contractor sha11 retain the services of one of the following Ceologists as a regular subcontractor to and to form a part of the Compressed Air Energy Storage Drilling and Testing Contract:

\author{
Mr. Ernest Loveless* \\ P.0. Box 238 \\ Monroe City, Indiana 47557 \\ Mr. Merle Williams* \\ P.0. Box 701 \\ Mt. Vernon, Illinois 62864
}

d1. The duties of the Consulting Geologist shall consist of the following:

d1.1 Sit on well

d1.2 Assist in directing drilling procedures

dl. 3 Study and describe the drill cuttings and core samples

d1.4 Pick formation contracts

d1.5 Determine coring and casing depths

d1.6 Coordinate the removal of core samples from the core barrel

d1.7 Assist in the running and cementing of all well casings

d1. 8 Coordinate the running of all survey logs

d1.9 Assist in performing fluid buildup curves

e. Testing Laboratory: Contractor shall retain the services of the following laboratory as a regular subcontractor to and to form a part of the Compressed Air Energy Storage Drilling and Testing Contract:

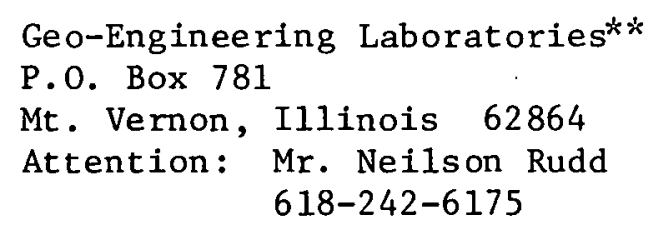

e1. The duties of the Testing Laboratory shall consist of the following:

el. 1 Box and transport the core samples to the laboratory

el.2 Analyze the core samples as directed

*This consultant or his equal will be selected for the actual specification. **This firm or its equal will be selected for the actual specification. 
el. 3 Preparation and submittal of core analyses reports

el.4 Storage of core samples

f. Water Analyses Services: Contractor shall retain the services of the following laboratory as a regular subcontractor to and to form a part of the Compressed Air Energy Storage Drilling and Testing Contract:

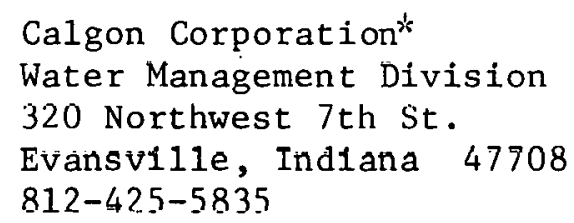

f1. The duties of the Water Analyses Services Contractor shall consist of the following: Analyze water samples for mineral content, $\mathrm{pH}$, total dissolved solids, and specific gravity.

g. Water Pump Test: Contractor shall retain the services of the following Company as a regular subcontractor to and to form a part of the Compressed Air Energy Storage Drilling and Testing Contract:

$$
\begin{aligned}
& \text { Reda Pump Co:" } \\
& \text { c/o John Cutright } \\
& \text { Tulsa, Oklahoma } \\
& 918-747-3668
\end{aligned}
$$

g1. The duties of the Water Pump Test Contractor shall consist of the following: Provide submersible pump and control panel.

h. Geophysical Logging: Contractor shall retain the services of one of the following companies as a regular subcontractor to and to form a part of the Compressed Air Energy Storage Drilling and Testing Contract:

$\begin{array}{lll}\text { Birdwel1* } & & \text { Schlumberger Well Services* } \\ \text { Drawer U } & & \text { P. O. Box 751 } \\ \text { Olney, Illinois } 62450 & \text { Mt. Vernon, Illinois } 62864 \\ 618-393-2188 & & 618-244-4992\end{array}$

h1. The duties of the Geophysical Logging Contractor shall consist of the following: Provide the following geophysical logs:

h1. 1 Electric-induction $\log$

h1.2 Neutron $\log$

h1.3 Simultaneous Compensated Neutron-Formation density logs

h1.4 3-D cement bond 1 log

*This firm or its equal will be selected for the actual specification. 
i. Mobilization and Demobilization: This item, as set forth in the Proposal Form, shall include all of the following and all items of a similar nature:

i1. Moving in of all equipment and supplies

12. Setting up all facilities for the WORK, Including all temporary facilities

i3. Moving out of all equipment and supplies and removal of all temporary facilities at completion of the WORK

105. SCHEDULE OF WORK

105.1 The Schedule of Work herein specified sets forth certain critical dates which Contractor is required to meet. However, the stipulation of these critical dates shall not relieve Contractor of the obligation to process the WORK, from start to completion, in an orderly and continuous manner during the course of the WORK.

105.2 At least once a month, or more often if requested by Purchaser, and on such date as designated by Purchaser, Contractor shall furnish such information as Purchaser deems necessary for reporting schedule progress and costs including, but not limited to, information related to schedule, costs, man-hours and work performed. Information shall be presented in the detail and format requested by Purchaser. Purchaser shall have the right to verify all data presented.

105.3 Scheduled Dates for Work by Contractor: In accordance with the foregoing requirements, Contractor shall perform the WORK in accordance with the following schedule:

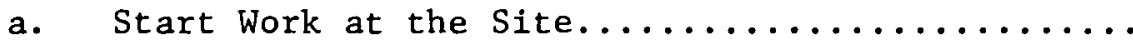

b. Complete Slimhole Structure Test Wells.........

c. Complete first Reservoir Injection-Withdrawal

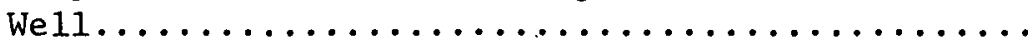

d. Complete two Reservoir Observation Wells........

e. Complete second Reservoir Injection-Withdrawal.

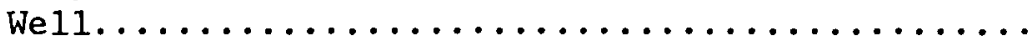

f. Complete Caprock Observation We11...........

g. Construct Water Disposal Pit..............

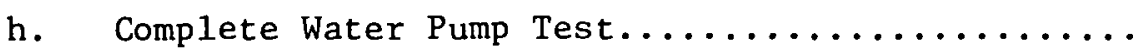

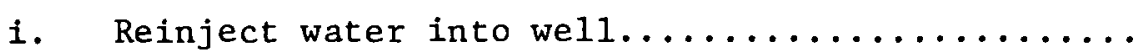

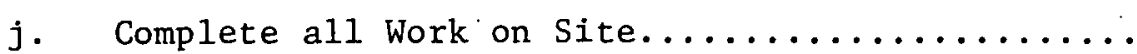

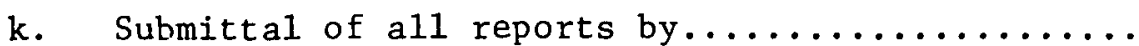


106. PERMITS

Contractor shall obtain permits required for the WORK. Contractor shall arrange with Purchaser for his representative to accompany Contractor in securing all such permits.

\section{DEFINITIONS}

107.1 Wherever the term "Job Specification" appears or is implied, it shall be construed to mean "Project Specification".

107.2 Wherever the terms "approved", "as approved", "satisfactory", "as requested", or other similar terms are used in this Specification, they shal.1. mean "as approved, etc., by the Purchaser", unless otherwise specifically stated:

107.3 Wherever the word "Purchaser" appears in the Bid Documents, it shall be construed to mean

107.4 Contractor is herewith designated as the Compressed Air Energy Storage Drilling and Testing Contractor.

108. SITE CONDITIONS

108.1 Examination of the Site:

a. Bidder shall visit the site during the Bid Period to familiarize himself with conditions under which the WORK is required to be done.

b. Bidder shall consult with Purchaser's representative as to means of access to the site of the WORK and methods to be used in unloading and bringing materials and equipment onto the site.

c. Contractor's later plea of ignorance of existing or foreseeable cond1tions which will create difficulties or hindrances in execution of the WORK will not be acceptable as an excuse for any failure on part of Contractor to fulfill in every detail all requirements of the spec1fication and/or drawings. Furthermore, Contractor's plea of ignorance will not be acceptable as the basis for any claim whatsoever for additional or extra compensation.

\subsection{Temporary Facilities:}

a. Domestic Water and Water for Mixing Mud and Cementing: Contractor shall provide his water and temporary appurtenant facilities required for the WORK.

b. Toilet Facilities: Contractor shall provide chemical toilet facilities for the use of employees and shall dispose of the wastes off the Project Site. These facilities shall be satisfactory in every respect to all governing bodies having jurisdiction. 
c. Temporary Light and Power: Contractor shall provide his own facilities.

d. Office and Construction Storage, Etc.:

d1. Any facilities required by Contractor sha11 be provided by Contractor at his own expense at a location acceptable to Purchaser.

d2. Al1 temporary buildings and associated electrical.work required by Contractor shall be erected and maintained by him. All buildings shall be of fire resistant construction.

e. Burning or Burying on the Premises: Burning or burying on the property will NOT be permitted.

f. Fire Protection: Contractor shall provide, and shall be fully responsible for handling the required fire fighting facilities and maintaining complete fire protection for his WORK.

g. Temporary Barricades: Contractor shall provide all temporary barricades, warning signs, danger lights, etc., which shall comply with all authorities having jurisdiction.

h. Watchmen Service: Contractor shall provide his own.

i. Removal of Temporary Facilities: Contractor shall remove all temporary facilities provided on the site for his own use at the termination of their usefulness or the termination of the WORK, or when requested, and shall leave the premises in condition satisfactory to Purchaser's representative in every respect.

\section{PROTECTION}

109.1 Various public and private utility lines, public and private roads, water wells, farm tile drains and other similar facilities and structures are within, or adjacent to, the site.

109.2 Contractor shall accordingly provide all protection as required, as approved or requested.

109.3 All due precautions shall be taken by Contractor to avoid damages to these facilities and structures and to properly operate and/or move all equipment and material with respect to these facilities and structures.

109.4 Contractor shall properly warn all of his employees with respect to any/all of these facilities or structures which constitute a hazard to these employees, and shall provide necessary protection for his employees.

109.5 Protection of Natural Environment: Extreme care shall be exercised throughout the course of the WORK to avoid damages to, or pollution of, existing vegetation, water facilities or other natural environmental features outside of the immediate areas of the WORK. 
Crop Damage: Contractor shall make arrangements with Purchaser's representative for the best access to drilling work areas, to cause least damage to crops. Purchaser will be responsible for all crop damage only when such damage was a necessity to the execution of the WORK and was not occasioned by carelessness or neglect on the part of Contractor. Contractor shall make prompt settlement of all claims that are due to Contractor's negligence. When claims are settled, Contractor shall supply Purchaser with three (3) copies of the damage release on a form approved by Purchaser. If release cannot be obtained, Purchaser will accept a copy of the check covering payment provided it is.a claim draft and states that "payment is for all damages incurred" on specific date that damage was done.

109.7 All adjacent public and private property shall be placed and left in as good a condition as it was before the WORK started.

109.8 Any damages, interruptions, etc., which do occur to the foregoing property, structures or facilities as a result of Contractor's acts of commission or of omission shall be remedied by Contractor at his own expense, including all premium time, if any, required to remedy damages, interruptions, etc., in shortest possible time and to the complete satisfaction of Purchaser's representative.

109.9 Public Good Will: Contractor shall carry on the WORK at all times so as to maintain the best possible relations among Purchaser, the Public, and Public Authorities. Contractor shall provide Courtesy signs for detours and for other inconvenience to the Public if requested to do so.

110. MAINTENANCE OF EXISTING ROADS

110.1 Contractor shall maintain existing roads and other similar improvements at or adjacent to the site and which are used by Contractor during the course of the WORK. Contractor shall not remove or alter any existing public improvements without approval of governing bodies having jurisdiction.

110.2 All maintenance shall be as required by governing bodies having jurisdiction.

111. LINES AND GRADES

111.1 Contractor shall lay out lines and grades from existing Section marks for the WORK.

111.2 Contractor shall notify Purchaser of any differences in location of existing work or conditions from that indicated, wherever such differences may affect the WORK.

112. CODES, STANDARDS AND REFERENCED PUBLICAT IONS

112.1 Conform to the referenced requirements of the codes, standards, and referenced publications listed herein. 
112.2 References herein to specific Paragraphs, Subparagraphs, Articles, Sections, Figures, etc., of these referenced publications are for conveniencc of reforence only, and shall not relieve the Contractor from any/all obligations of the applicable requirements of these referenced documents.

113. ACCOUNTING RECORDS

Contractor shall furnish Purchaser with such statements, payrolls, invoices, and other sustaining papers, as may be required to provide Purchaser with a clear and adequate record of payments by Contractor under the Contract. Purchaser shall have the right at any time to inspect Contractor's accounting records. Contractor further agrees to keep, proLECL, and make available to Purchaser, for a period of three years after completion of the WORK, records and books of account pertaining to the WORK. 


\section{DIVISION 2 - S"I'ANDARD AND DRAWINGS}

\section{DESIGN DRAWINGS (CONSULTING ENGINEERS')}

201.1 The following Design Drawings by the Consulting Engineers, dated hereof : ; unless otherwise noted, are attached hereto and form a part

S-1 - Construction of Injection - Withdrawal Wells.

S-2 - Construction of Reservoir Observation Wells.

S-3 - Construction of Caprock Observation Wells.

S-4 - Schematic Drawing of Water Holding Pond.

202. DATA (CONTRACTOR'S)

202.1 Submittal of data shall conform to the requirements herein specified.

202.2 Submittal Distribution: Contractor shall address and submit correspondence and data as follows:

a. Correspondence:

a1. Correspondence, except as specified in Paragraphs 202.2al and 202.2b shail be addressed and submitted to:

Purchaser

b. Data:

b1. Address and submit original copy of transmittal letter and data to:

Purchaser

203. DRILLER'S. FIELD RECORDS

203.1 Two copies of the driller's tour sheets, driller's time sheets and Geolograph Record*shall be forwarded to Purchaser's office not later than noon of the day following completlun of each wcll. All dri,1ler's logs shall be delivered to:

\section{Purchaser}


203.2 Three typed copies of the field records shall be forwarded to the same address and shall reach the above address not later than fifteen days after the completion of each well.

204. SOIL DRILLER'S RECORDS

204.1 The soil driller for the water disposal pit borings, as outlined in Division 5, shall forward two coples of the driller's field log to Purchaser's oflice nut later than noon of the day following completion of each well.

204.2 Driller's logs sha11 be delivered to the following address:

\author{
Purchaser
}

204.3 Three typed copies of the field log shall be forwarded to the above address not later than fifteen days after the completion of each well.

204.4 Each log shall contain the information specified in Paragraph 501.3.

205. REPORTS

205.1 Contractor shall submit daily progress reports to Purchaser for verification. These reports shall detail the work performed during the day including the total footage drilled by each crew, with a breakdown for each well for the type of drilling (i.e., standard split-spoon, rock coring, auger boring, and so forth), the number and type of test performed per well, the number of crew hours, measured to the nearest $1 / 6$ hour, each $\mathrm{rig}$ and crew used or out of production for the purpose of special testing, special sampling, and percolation tests, as well as any downtimes affecting the progress of work.

205.2 Progress reports and time and material records shall be submitted to Purchaser, on forms as approved by Purchaser, not later than noon of the working day following the date of the report. Purchaser will not be responsible for any payment delays resulting from failure to submit accurate progress reports on schedule. No payment will be made for work which has not been verified by Purchaser's representative.

206. PACKING AND SHIPPING SAMPLES

206.1 Each airtight container for soil, rock or water samples for each well shall be carefully labeled showing the following information:

a. The number of the well from which the sample was taken.

b. Depth of the sample below ground. 
c. Standard penetration resistance in split-spoon sample borings.

d. Date sample was taken.

e. Name of project location.

f. Purchaser's project identification number.

206.2 All samples shall be carefully packed to prevent damage during storage or shipment. Packages containing airtight container samples and thin-walled tube samples shall be marked "Fragile and Perishable Keep from Heat or Cold". Each set of samples shall be sent to the responsible laboratory as specified in Paragraph 104.3. 


\section{DIVISION 3 - SLIMHOLE STRUCTURE TEST WELLS}

301. GENERAL

301.1 Prior to drilling of wells, a Registered Surveyor shall be retained to determine the exact locations and elevations of the wells. Work from existing section lines and bench marks at the Project site. The responsibili.ty for accuracy of locations and elevations remains with Contractor.

301.2 Survey to third order accuracy standards $(1: 5000)$.

301.3 If a well cannot be located within the allowable tolerance for any reason, advise Purchaser prior to drilling at a different location, for approval.

301.4 Any new culverts required for access to the drilling locations shall be furnished and installed by Contractor in accordance with the requirements of the State Road Commissioner. The culverts shall be removed after each well has been drilled, if requested by the land owner or the State Road Commissioner.

\section{EQUIPMENT AND MATERIALS}

302.1 Drilling Equipment: Rotary drilling equipment, capable of drilling holes four to six inches in diameter to a depth of 2000 feet and shall be equipped with a Geolograph Recorder.*

302.2 Materials:

a. Well Casing: Temporary surface casing shall be of sufficient size to accommodate all specified dirilling and geophysical tools.

b. Drilling Mud: Dresser Magcobar** or NL.Baroid** of sufficient consistency to clear the hole and carry representative formation sample cuttings from hole.

c. Water: Potable. (Storage of water for cementing shall be in a tank or tank truck.)

d. Cement: Pozmix cement (Halliburton" or Dowe11”).

303. CONSTRUCTION OF WELLS

303.1 General:

a. A mud pit shall be excavated adjacent to the well for the mixing and storing of drilling mud. The top soil shall be stockpiled,

*This equipment or its equal will be selected for the actual specification. **This material or its equal will be selected for the actual specification. \#This firm or its equal will be selected for the actual specification. 
and at the completion of its usefulness the mud shall be removed and the pit back-filled. Using the topsoil previously stored on site, the area shall be restored to the satisfaction of Purchaser.

b. Prepare the area whcre the work will be performed so that the working stage drains away from the well holes.

c. Drill the wells using a portable rotary drill rig.

\subsection{Well Drilling:}

a. Mix drilling mud (Dresser Magcobar* or NL Baroid*) of sufficient weight and consistency to clean the hole and to carry good representative sample cuttings of formations from the hole.

b. Drill a borehole and run surface casing from ground level through overburden to top of bedrock at a depth of approximately feet. Surface casing shall be of sufficient size to accommodate $\overline{\mathrm{dr}}$ illing tools.

c. Drill a livle at least $4-1 / 2$ inch in diameter from bedrock surface through a kiluwn stratigraphic marker to an anticipated depth of approximately feet or of sufficient depth to record the stratigraphic marker on genphysical furvey ling.

d. Run an electric-induction survey log (Schlumberger** or Birdwell**) from bottom of hole to ground surface.

e. The surface casing shall be removed wherever possible. Where the casing cannot be removed, Contractor shall cut off the casing three feet below ground level.

f. Run drill pipe in hole to total depth and completely fill the hole with pozmix cement (Halliburton*t or Dowell**) to 3 feet below the ground surface. Cementing the hole shall be performed using a minimum of two stages.

g. At the completion of its usefulness, the mud shall be removed from the mud pit and the pit shall be hack-filled. Remove enough of the drill cuttings from the mud pit to obtain the original contour grade when covered with three feet of soil cover. Using the topsoil previously stored on site, the area shall be restored to the satisfaction of the Project Manager's representative.

\section{DRILL CUTTINGS SAMPLES}

304.1 Samples of the drill cuttings shall be collected at five foot intervals from the top of bedrock to total depth unless otherwise requested by the Well Sitter (Consulting Geologists).

305. PLUGGING OF WELLS

305.1 General: Plug wells from the total depth to 3 feet below ground surface.

*This material or its equal will be selected for the actual specification. **This firm or its equal will be selected for the actual specification. 
305.2 Materials: Pozmix cement (Halliburton* or Dowel1*).

305.3 Me thod:

a. All reasonable effort shall be made to pull out temporary surface casing. Casings left in place shall be at Contractor's expense.

b. The well shall be filled with pozmix cement through the drill pipe from total depth to 3 feet below ground surface.

c. Contractor will be allowed to plug wells in stages as necessary to prevent loss of drill pipe due to flash setting of cement.

d. If the temporary surface casing cannot be removed, Contractor shall remove that casing which can be removed by unscrewing it. If none can be removed, the casing shall be cut off three feet below the ground level.

306. REMOVAL OF MUD PIT

306.1 After the well has been completed, the mud shall be removed from the pit and the pit area back-filled. Using the topsoil previously stored on site, the area shall be restored to the satisfaction of Purchaser.

*This firm or its equal will be selected for the actual specification. 


\section{THIS PAGE}

\section{WAS INTENTIONALLY \\ LEFT BLANK}


SARGENT \& LUNDY

ENGINEERS CHICAGO
Spec. No. G-3600

Issue:

COMPRESSED AIR ENERGY STORAGE DRILLING AND TESTING

DIVISION 4 - INJECTION/WITHDRAWAL WELLS AND OBSERVATION WELLS

401. GENERAL

401.1 Prior to drilling of wells, a Registered Surveyor shall be retained to determine the exact locations and elevations of the wells. Work from existing section lines and bench marks at the Project Site. The responsibility for accuracy of locations and elevations remains with Contractor.

401.2 Survey to third order accuracy standards $(1: 5000)$.

401.3 If a well cannot be located within the allowable tolerance for any reason, advise Purchaser prior to drilling at a different location, for approval.

401.4 Any new culverts required for access to the drilling locations shall be furnished and installed by Contractor in accordance with the requirements of the State Road Commissioner. The culverts shall be removed after each well has been drilled, if requested by the land owner or the State Road Commissioner.

402. EQUIPMENT AND MATERIALS

402.1 Drilling Equipment: Heavy-duty rotary drilling equipment, capable of drilling wells up to 14 inches in diameter to a depth of 3000 feet and shall be equipped with a Geolograph Recorder.*

402.2 Materials:

a. Well Casing:

al. 7-inch 0.D., steel, 10 lb./ft., threaded and coupled 8 rd. thread, Range 2, API, Bare (no mill coating) J-55.

a2. 4-1/2 inch 0.D., steel, 9-1/2 1b./ft., threaded and coupled, $8 \mathrm{rd}$. thread, Range 2, API, Bare (no mill coating) H-40.

a3. 10-3/4 inch O.D., steel, 40.5 lb./ft., threaded and coupled, $8 \mathrm{rd}$. thread, Range 2, API, J-55.

a4. 8-5/8 inch 0.D., steel, $24 \mathrm{lb} . / \mathrm{ft}$., threaded and coupled, $8 \mathrm{rd}$. thread, Range 2, API, H-40.

Note: Contractor shall perform a sonoscope and magnetic particle inspection on all 7-inch casing joints prior to installation.

\#This equipment or its equal will be selected for the actual specification. 
b. Cement:

bl. Cementing Surface Casing: Class A cement with $4 \%$ calcium chloride conforming to requirements of API, Spec. 10 (1977).

b2. Cementing Long String Casing: Pozmix cement with $10 \%$ salt, $0.75 \%$ CFR2 and 12.5 lbs./sack gilsonite (Halliburton* or Dowell*).

c. Water: Potable (storage of water for cementing shall be in a tank or tank truck).

403. CONSTRUCTION OF INJECTION/WITHDRAWAL WELLS

403.1 Gieneral:

a. Prior to drilling of wells, a mud pit shall be excavated adjacent to each well for the mixing and storing of drilling mud. At the completion of its usefulness the mud shall be removed and the pit backfilled. Remove enough of the drill cuttings from the mud pit to obtain the original contour grade when covered with three feet of soil cover. Using the topsoil previously stored on site, the area shall be restored to the satisfaction of Purchaser.

b. Remove spoil from the stage area so that it will not interfere with drilling operations. Dispose of the spoil on the premises where and as directed by Purchaser.

c. Drill the wells using rotary drilling equipment. Other types of drilling shall not be utilized by the Contractor without prior approval of Purchaser.

403.2 Well drilling:

a. Drill a 13-3/4 inch diameter (minimum) hole from ground level through the uverburden into bedrock to an estimated depth of feet.

b. Using the one-plug method and Class $A$ cement, install and cement a 10-3/4 inch 0.D. well casing from ground level to the bottom of the hole. The top of the top joint shall be set 1'-4" above ground level. The casing shall be centered in the rotary table and supported for a minimum of six hours after cementing.

c. The casing shall be cut off at the bottom of the casing coupling and a slip-on head casing housing shall be set level and seal-welded to the top of casing.

d. Go into the well with a 9-7/8 inch drill bit and 9-13/16 inch 0.D. stabilizers. One stabilizer shall be placed immediately above the drill bit followed by a 10-foot drill collar. A second stabilizer shall be placed on the 10-foot drill collar followed by another full length drill collar. A third stabilizer shall be placed on top of the full length drill collar.

\#This firm or its equal will be selected for the actual specification. 
e. Injection - Withdrawal Well 非: Contractor, using a 9-7/8 inch bit, shall drill to an estimated depth of __ feet:

f. Injection - Withdrawal Well 非: Contractor, using a 9-7/8 inch bit,

$\checkmark$ shall drill to an estimated depth of __ feet. No coring will be required to be performed.

g. Drilling mud shall be circulated in the borehole until all drill cuttings are removed from the hole and to prevent artesian flow from the well while removing the drilling tools.

h. Core Drilling Injection/Withdrawal Well 非:

hl. Run a 3-l/? inch T.n. diamond coring bit in the hole with a stabilized core barrel that will permit the core drilling of at least 25 feet of formation each trip into the hole.

h2. Core drilling shall be performed from the top of the proximately feet) to the total well depth at approximately feet. Bactericide shall be mixed with the drilling mud and used for all work below the foot level. The drilling mud used in the drilling through the reservoir unit (approximately feet) shall have a minimum weight of 9 pounds/gal. and the mud's water loss is less than $6 \mathrm{cc}$, conforming to requirement of API RP 13B (1976).

h3. Drilling mud shall be circulated in the hole until the hole is clean. The hole shall be kept full of drilling mud during the removal of the core drill equipment.

h4. If core bit used is less than 9-7/8 inch 0.D., go back in hole with 9-7/8 inch drill bit and stabilizers and ream hole to total depth.

i. Run a Simultaneous Compensated Neutron-Formation Density Log in the well from total depth to the surface of the ground.

j. Using the 2-plug method and pozmix cement, run and cement a 7 inch $0 . D$. casing to within 6 inches of the total depth. Use power tongs, adjusted to the recommended API torque rating, to make up the string of 7 inch O.D. casing. Use a guide shoe, float collar, 12 hinged centralizers (approximately 200 feet apart, with the first centralizer 5 feet above the guide shoe), 200 feet of rotary scratchers (all the way through the reservoir unit and pozmix cement with $10 \%$ salt, $.75 \%$ CFR2 and 12.5 pounds per sack gilsonite. Rotate casing during circulation, cementing and displacement. Circulate well for at least 20 minutes before cementing is started. Use one sack of Quadrofos* or mud flush in a $10 \mathrm{bbl}$. water blanket ahead of the cement. After wiper plug has bumped the float collar, open valve on pump truck and check for bleed back through the float collar check valve.

k. Remove the slips from the rotary table and place the casinghead.slips around the 7 inch $O . D$. casing in the casinghead.

*This material or its equal will be selected for the actual specification. 
1. Cut off the 7 inch O.D. casing 6 inches above the top of the casinghead and spot weld a steel plate over the end of the casing.

404. CONSTRUCTION OF RESERVOIR WELLS

404.1 General:

a. Prior to drilling of wells, a mud pit shall be excavated adjacent to each well for the mixing and storing of drilling mud. At the completion of its usefulness the mud shall be removed and the pit backfilled. Remove enough of the drill cuttings from the mud pit to obtain the original contour grade when covered with three feet of soil cover. Using the topsoil previously stored on site, the area shall be restored to the satisfaction of Purchaocr.

b. Remove spoil from the stage area so that it will not interfere with drilling operations. Dispose of the spoil on the premises where and as directed by Purchaser.

c. Drill the wells using rotary drilling equipment. Other types of drilling shall not be utilized by the Contractor without prior approval of Purchaser.

404.2 Wull Drilling:

a. Drill a 12-1/4 inch diameter (minimum) borehole from ground level through the overburden into bedrock to an estimated depth of feet.

b. Using Class $A$ cement, install and cement an 8-5/8 inch O.D. diameter casing from ground level to the bottom of the borehole using a oneplug method. The casing shall be centered in the rotary table and supported for a minimum of six hours after cementing. Set the top of the coupling on the top joint 2 inches above ground level.

c. A threaded casinghead housing shall be connected to the top of the surface pipe.

d. Go in hole with drilling tools and 7-7/8 inch bit and 7-13/16 inch $0 . D$. stabilizers. Place one of the stabilizers imediately above the drill bit. Place a $10 \mathrm{ft}$. drill collar immediately above the stabilizer. Place the second stabilizer immediately above the $10 \mathrm{ft}$. drill collar. Place a full length drill collar immediately above the second stabilizer and place the third stabilizer imediately above the full length drill collar. (The $10 \mathrm{ft}$. collar and three stabilizers can be rented from Drilco* or Christensen Diamond Products Co.*)

e. Drill with the $7-7 / 8$ inch bit to an estimated depth of _ $\mathrm{ft}$.

f. Remove the drilling tools from the hole. (Keep hole full of drilling mud while roning out of hole.)

*This firm or its equal will be selected for the actual specification. 
g. Core Drilling:

g1. Run a diamond core bit that will cut $3-1 / 2$ inch $0 . \mathrm{D}$. cores and a stabilized core barrel that can recover at least $25 \mathrm{ft}$. of core samples each trip.

g2. Core drill the remainder of the well through the reservoir unit to approximately ft. (coring will be performed in each of the observation wells). The core samples shall be boxed and transported to their laboratory by personnel from Geo-Engineering Laboratories, Inc., Mt. Vernon, Ill.*

g3. Be sure that the mud weight is $91 \mathrm{~b} . / \mathrm{gal}$. and the water 1 os 8 is less than $6 \mathrm{cc}$. before penetrating the reservoir unit at approximately ft. Mix bactericide in the drilling mude before drilling below $\mathrm{ft}$.

g4. Circulate the hole clean and remove coring tools from hole.

h. Run a Simultaneous Compensated Neutron-Formatiun Density Survey Log in the well from total depth to the ground surface.

i. Run and cement 4-1/2 0.D. casing to 6 inches above the total depth using 2-plug method. Use power tongs, adjusted to the recommended API torque rating, to make up the string of 4-1/2 $0 . D$. casing. Use a guide shoe, float collar, 13 centralizers, $200 \mathrm{ft}$. of rotary scratchers (through the total thickness of the reservoir unit at a depth of approximately $2200 \mathrm{ft}$. and 900 sacks of pozmix cement with $10 \%$ salt, .75\% CFR2 and 12.5 pounds per sack of gilsonite. Use cementing company's (Dowel1* or Halliburton*) rotating head and rotate casing during circulation, cementing and displacement. Use one sack of Quadrofos** or mud flush in a $10 \mathrm{bbl}$. water blanket ahead of the cement.

j. Remove slips from rotary table and seat the casing in the casinghead housing with the casinghead housing slips.

k. Cut off the 4-1/2 inch casing one foot above the casinghead housing and spot weld a steel plate on the end of the casing.

\section{CONSTRUCTION OF CAPROCK OBSERVATION WELL}

\subsection{General:}

a. Prior to drilling of wells, a mud pit shall be excavated adjacent to each well for the mixing and storing of drilling mud. At the completion of its usefulness the mud shall be removed, the pit back-filled, and the area restored to the satisfaction of Purchaser.

b. Remove spoil from the stage area so that it will not interfere with drilling operations. Dispose of the spoil on the premises where and as directed by Purchaser.

*This firm or its equal will be selected for the actual specification. 
c. Drill the wells using rotary drilling equipment. Other types of drillings shall not be utilized by the Contractor without prior approval of Purchaser.

405.2 Well Drilling:

a. Drill a 12-1/4 inch diameter (minimum) borehole from ground level through the overburden into bedrock to an estimated depth of

feet.

b. Using Class A cement, install and cement an 8-5/8 inch O.D. surface casing from ground level to the bottom of the borehole using a oneplug metliud. The casing shall be centered in the rotary table and supported for a minimum of six hours after rementing. Sat the top of the coupling on the top joint 2 inches above ground level.

c. A threaded casinghead housing shall be connected to the top of the surface pipe.

d. Go into the well with a 7-7/8 inch drill bit and three 7-13/16 inch $0 . D$. stabilizers. Place one of the stabilizers immediately above the drill bit. Place a 10-ft. drill collar immediately above the stabilizer. Place the second stabilizer immediately above the 10 ft. drill collar. Place a full length drill collar immediately above the second stabilizer and place the third stabilizer immediately above the full length drill collar.

e. Drill with the 7-7/8 inch bit through a porous zone in the caprock above the reservoir unit to approximately ft. (to be determined from survey logs and core samples from the other four wells).

f. Run a Simultaneous Compensated Neutron-Formation Density Survey Log in the well from total depth to the ground surface.

g. Run and cement 4-1/2 0.D. casing to 6 inches above total depth using 2-plug method. Use power tongs, adjusted to the recommended API torque rating, to make up the string of 4-1/2 0.D. casing. Use a guide shoe, float collar, 11 centralizers, rotary scratchers (through the total thiekness of the porous zone and 770 sacks of pozmix cement with $10 \%$ salt, $0.75 \%$ CFR2 and 12.5 pounds per sack of gilsonite. Use cementing company's rotating head and rotate casing during circulation, cementing and displacement.

h. Remove slips from rotary table and seat the casing in the casinghead housing with the casinghead slips.

i. Cut of the 4-1/2 inch casing one foot above the casinghead housing and spot weld a steel plate on the end of the casing.

406. ALIGNMENT AND PLUMBNESS

406.1 The wells shall be drilled straight with a maximum deviation from the vertical of four degrees. Contractor shall check holes for deviation by using a sure-shot when requested by Purchaser. 
406.2 In event well is out of alignment or plumbness, Purchaser reserves the right to reject well or require any discrepancies to be rectified at no cost to Purchaser.

406.3 If well discrepancies cannot be rectified the well shall be abandoned and sealed. Sealing of abandoned wells shall conform to the requirements as set forth in the State of Illinois Publication An Act in Relation to Oil, Gas, Coal and Other Surface and Underground Resources and Rules and Regulations, Department of Mines and Minerals, Division of 0il and Gas, latest revision, and to any other applicable state and local authorities.

406.4 Purchaser will notify Representative of Mining Board whenever a well is to be abandoned and sealed. Contractor shall not proceed to seal well until Purchaser has notified the Mining Board.

407. WELL PERFORATING

407.1 After the five wells have been drilled, obtain a cable tool drilling rig with jars, sinker bar, a swab, and a bailer for 4-1/2 inch 0.D. and 7 inch 0. . casing.

407.2 Remove the steel plate from well casings.

407.3 Run 3-D Cement Bond Survey Logs (Birdwel1*) in the five wells.

407.4 Bail approximately feet of fluid from each well.

407.5 Perforate the casing in the upper 10 foot interval in the two reservoir observation wells, the upper 20 foot interval in the two reservoir injection/withdrawal wells, and all of the porous zone in the caprock observation well. The casing in all five wells shall be perforated with 4 jet shots per foot in the perforated zone.

407.6 After perforating each well, swab sufficient fluid from well to be assured that only formation water remains in wellbore. At end of swabbing perform a fluid level build-up test.

407.7 Obtain 3 one-quart samples of the water from each well after it has been swabbed sufficiently to obtain only formation water.

407.8 Test samples as per Article 409.

408. CORE ANALYSES

408.1 Core samples shall be boxed and transported by personnel of GeoEngineering Laboratories* for analyses to be performed by Geo-Engineering Laboratories.*

408.2 The following analysis shall be performed on the reservoir core samples: whole core analysis consisting of horizontal and vertical permeabilities, percent porosity, and water content.

*This firm or its equal will be selected for the actual specification. 
408.3 The caprock core shall be analyzed for percent of porosity and vertical permeability. Threshold pressure will be analyzed to 800 psi for the bottom 50 feet of the caprock (imediately above the reservoir).

409. WATER TESTING

409.1 Send one of the samples from each well to Calgon Corp.*

409.2 Have samples analyzed for mineral content, pH, total dissolved solids, and specific gravity.

410. SAMPLE AND DRILLING TIME

410.1 Collect 5-foot samples of the drill cuttings from 5 feet to total depth, except where core samples are obtained.

*This firm or its equal will be selected for the actual specification.

$$
\text { 4-8 }
$$

Final Page of Division 4 


\section{DIVISION 5 - CONSTRUCTION OF WATER HOLDING POND}

501. DRILLING AND SAMPLING

501.1 Prior to construction of the water holding pond, Contractor shall survey the area to determine the location and elevation of all borings. All borings as indicated on the drawings shall extend 25 . feet below the existing ground surface.

501.2 Drilling fluld other than water may be used to stabilize the borehole only in those borings where no percolation tests are to be performed. Borings, where such tests are required, w1ll be indicated on the drawIng.

501.3 The following data shall be required for all borings:

a. Location of the boring

b. Surface elevation

c. Depth of boring

d. Description of soll encountered

e. Layer thickness

f. Penetration and recover length

g. Groundwater level reading during and after the boring

h. SPT $N$ values (blows/ft)

501.4 In cases where cohesive soll is encountered the shelby tube sampling procedure shall be used to obtain undisturbed soil samples in accordance with ASTM Specification D1587. A minimum of two shelby tube samples shall be required for each borehole. All samples shall be sealed 1mmediately at the site and returned to the laboratory.

501.5 Representative soll samples shall be obtained by means of splitbarrel sampling in accordance with ASTM Specification D1856. SPT N values and pocket penetrometer values shall be recorded.

501.6 Bag samples of 40 pounds from a depth of two to five feet shall be obtained for laboratory testing. Each bag sample shall contain a soll sample with an alrtight container for fleld moisture content determination by the laboratory. Bag sampling location shall be indicated on the drawing. 
501.7 All borings shall be backfilled by grouting as directed by Purchaser. 502. LABORATORY TESTS

502.1 Index and Classification Tests:

a. Gradation Analys1s: Conform to ASTM D421, D422, and D2217. The results shall be presented in the form of graln size curves.

b. Percent Fines: Conform tó ASTM D1140.

c. Atterberg Limits: Conform to ASTM D423, D424, and D427.

d. Specific Gravity: Conform to $\Lambda$ STM D85/.

e. Soil Description: Conform to ASTM D2488.

f. Soil Classiffcation: Conform to ASTM D2487.

502.2 Physical and Chemical Properties Tests:

a. Bulk Unit Weight: Conform to the Corps of Engineers EM 1110-2-1906 or ASTM procedures.

b. Water Content: Conform to ASTM D2216 and D2974.

c. Organic Content: Conform to ASTM D2974.

d. Relative Density: Conform to the Corps of Englneers EM 1110-2-1906 or ASTM D2049.

e. Compaction: Conform to A'STM D698.

f. Permeabllity Test: Conform to ASTM D2434 or Corps of Engineers EM 1110-2-1906.

g. Shear Strength Tests:

g1. Unconfined Compression: Conform to ASTM D2166; the results shall be presented in the form of stress-strain plots.

g2. Unconsolfdated undrained test on the compacted cohesive material conform to ASTM D2850.

g3. Consolidated undrained test in the compacted cohesive material conform to Corps of Engineers EM 1110-2-1906.

503. PERCOLATION TESTS

503.1 Percolation tests shall be made in the overburden in selected zones of those borings indicated on the drawing. Tests shall be conducted In stages as the drilling progresses. Contractor shall furnish, malntain, and operate all pumps, flow-meters, hoses, drilling rigs, and miscellaneous equipment required for conducting the tests. 
503.2 Water may be supplied through any suitable pump or by gravity flow fjom a tank or similar source so long as sufficlent capacity to ktep the casing full of water is developed. Water shall be free of suspended sediments or other material which would reduce the porosity of the soll.

503.3 Contractor shall insure that a complete percolation testing equipment setup is avallable and properly maintalned so that equipment is avallable for testing at such times as the tests are required.

503.4 All percolation testing shall be performed in accordance with the following procedure:

a. Tests shall be conducted in an open section of the borehole both with the casing flush and extending 12 to 18 inches from the bottom of the hole. After the split-spoon or shelby tube sample has been removed from the bottom of the section of the borehole to be tested, the casing shall be driven to the top of the interval to be tested. Every effort shall be made to Insure that a good seal is malntained between the casing and the borehole wall during driving.

b. The borehole interval to be tested shall be reamed and/or flushed to develop a relatively clean, uniform hole free from cuttings or loose soll. Care shall be taken to prevent jetting of the borehole walls or bottom during reaming and/or flushing. Flushing shall be continued unt1l the return water is clear.

c. The hole shall be filled with water to a level within 5 feet from the top of the casing. This level shall be maintained for a pertod of 24 hours by adding necessary water to develop a steady seepage condition around the bottom of the borehole.

d. The water level inside the casing being adjusted for the last time, the depth to the water shall be carefully measured, recorded, and a timer started. The level of water may be allowed to drop inside the hole due to seepage through the flush bottom of the hole. The depth of water inside the casing shall be carefully recorded at $1 / 2,1,2$, $4,8,12$ and 24 hours.

e. The casing shall be pulled up 10 to 18 inches and that distance carefully recorded. Requirements as specifled in Paragraph 503.4d shall be repeated to determine the data necessary for the calculation of radial permeablitty.

f. In the event that there is caving in the overburden below the casing, the length of test interval may be reduced. The testing procedure for shorter intervals shall be the same as specified above.

504. EARTHWORK

504.1 General: Conform to the applicable requirements of Standard Specification and to the requirements hereinafter specified. 
504.2 Services of Testing Laboratory: Contractor shall provide testing services for use in connection with controlled compacted fill. Frequency of tests for in-place density values shall be one test for each $4000 \mathrm{sq}$. ft. of each 8 inch deep layer.

504.3 Cleanting and Grubhing: As spccificd in Form 1714.

504.4 Removal of Topsoil: Topsoll to a depth of 1'-6" shall be removed and stored on site, in areas where indicated or requested.

504.5 Excavation: Excavation shall conform to requirements of Form 1714 and to the following requirements:

a. Topso11, sod and organtc matter shall be stripped from the dike area.

b. Sultably stripped soll surfaces within the dike area shall be scarified to a depth of 6 inchco leveled and compacted by not less than 3 passes of a pneumatic tired roller or approved equal.

c. Stripping, leveling and compacting of soll surface on which embankment fili is to be placed shail be accomplished to the satisfaction of Purchaser.

d. Inspections and density tests of the foundation subgrade of the dam will be performed by the testing laboratory.

504.6 Material: Dike fill shall be of impervious material obtained from material previously excavated by the Contractor. All fill material shall be approved by Purchaser.

504.7 Compaction Densities:

a. Dike fill material shall be compacted to a minimum dry density equal to or greater than $95 \%$ of the maximum value obtained in the standard Compaction test, ASTM 698.

504.8 Placing:

a. The maximum loose $11 \mathrm{ft}$ thickness of fill material shall not exceed 8 inches.

b. Under no circumstances shall 1ce, snow or frozen material be Incorporated in the f11l. In the event that the fill surface becomes frozen during construction, all frozen materials shall be excavated from the $f 111$ and wasted before additional mațerial is placed.

\section{SLOPE PROTECTION}

505.1 Seed slopes to prevent erosion due to surface runoff, in accordance with the applicable section of the Standard Spectfications for Road and Bridge Construction, of the Division of Highways, Department of Public Works and Bulldings, State of Illinois, latest edition. 


\section{SARGENT \& LUNDY}

ENGINEERS

CHICAGO

G-3600

506. SEEPAGE CONTROL

506.1 Sand lenses and pockets exposed at the surface of the pond shall be over-excavated three feet and replaced by suitably compacted fill material, as specifled in Article 504.

507. DEMOLITION WORK

After the pump testing, Contractor shall abandon the dike and backfill the excavated area with the dike material. He shall back-grade the water holding pond area to its original condition to the complete satisfaction of Purchaser. 
601. GENERAL

601.1 Contractor shall perform a water pumping test of the structure to hydrostatically test the caprock, to determine its reliability as a caprock for the proposed underlying reservoir unit and to obtain in situ hydrogeologic characceristics, i.e. perwédility, of the reservoir.

601.2 Information shall be obtained from the pumped well and the remaining four wells that will be used for observation.

602. MATERIALS AND EQUIPMENT

602.1 The pumping equipment shall consist of a Reda*submersible pump run on $1000 \mathrm{ft}$. of 2-7/8 inch 0.D. upset tubing. A Reda Pump Company representative will size the pump and supervise installation of the pump assembly and control panel.

602.2 Continuous water level recorders (Stephens type "F"*) shall be furnished and installed by Contractor for the four observation wells. Contractor shall submit specifications for the proposed recorders. The recorder installations shall be protected by metal cover boxes.

602.3 Use an acoustic water level finder to measure fluid levels in the pumping well.

602.4 Provide piping, flow meter and screen.

602.5 Use a continuous recording barograph prior to and during the pumping test.

602.6 Use approved equipment for water reinjection:

603. EXECUTION

603.1 Contractor shall install the pump assembly in a 7-inch diameter injection - withdrawal we11 at an approximate depth of $1000 \mathrm{ft}$. Contractor shall provide power for the pump by installing a temporary electrical line to the pumping location.

603.2 Contractor shall install continuous water level recorders, protected by metal cover boxes, on each of the four observation wellheads. The four observation wells are the non-pumping injection - withdrawal well, the two reservoir observation wells, and the caprock observation well.

*This equipment or its equal will be selected for the actual specification. 
603.3 Contractor shall start recording barograph two months before pumping.

603.4 Contractor shall record water levels on all observation wells for at least one month prior to the start of the pumping test.

603.5 Contractor shall determine the barometric efficiency of the four observation wells prior to the pumping test. Barograph readings, converted to equivalent feet of water, shall be compared with well water level fluctuations for a period not less than five consecutive days. The purpose is to determine the effect of barometric pressure changes on well water levels.

603.6 Contractor shall pump water from the pumping well to the water holding pond continuously for a period of 60 to 90 days at a rate of approximately $100 \mathrm{gpm}$ (the exact period of time shall be determined by the capacity of the pump and the amount of drawdown). An accurate log shall be maintained of the pumping test downtime, if it or.curs.

603.7 Contractor shall obtain water level and barograph information as specified in Article 604 of this Specification. The water level recorder and barograph recording charts shall be changed as required or as directed by Purchaser.

603.8 Contractor sha11 under the supervision of the Reda Pumpt representative, remove the pump assembly and equipment from the well at the conclusion of the pumping period upon Purchaser's approval.

603.9 Contractor shall reinject filtered water from the water holding : pond back into down structure observation wells. Contractor shall comply with all regulations of governing bodies having jurisdiction relative to well reinjection.

603.10 Contractor shall back-fill water holding pond as specified in Division 5.

604. DATA COLLECTION

604.1 Contractor shall ensure that water levels are accurately measured and recorded to the nearest 0.01 foot in each of the four observation wells according to the following schedule:

a. First day:

al. Every minute during first 10 minutes.

a2. Every 5 minutes during next 30 minutes.

a3. Every 1/2 hour thereafter.

b. Second and third days - every hour.

c. Thereafter - once daily.

*This firm or its equal will be selected for the actual specification. 
SARGENT \& LUNDY

ENGINEERS

CHICAGO

604.2 Contractor shall ensure that barometric pressures are accurately measured and recorded to the nearest 0.01 inch $\mathrm{Hg}$ during the pumping teot. The barograph readings shall be periodically checked for accuracy with barometric pressures reported by the nearest U.S. Weather Bureau.

604.3 Contractor shall record pumping rate at a minimum of once daily. 


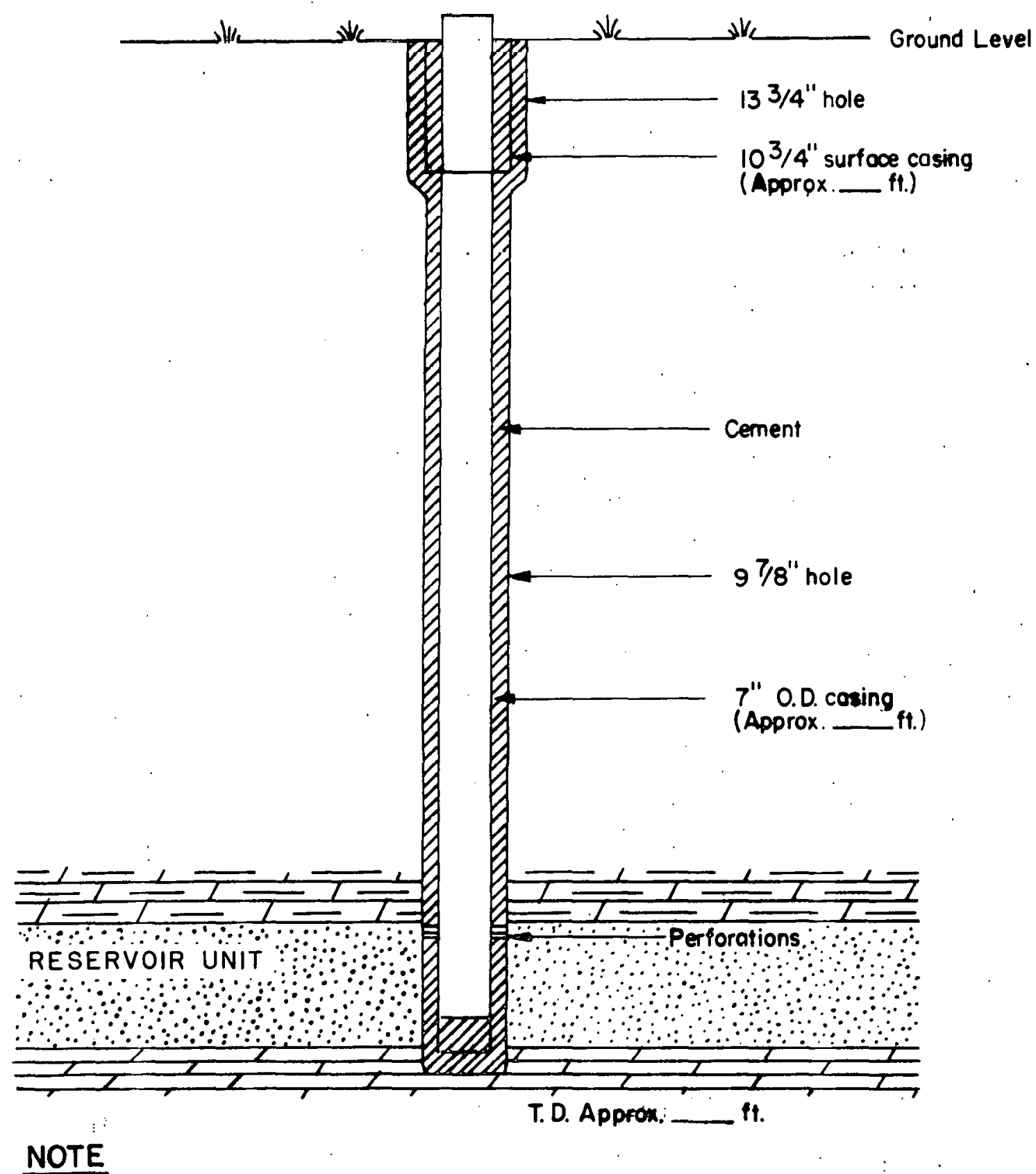

1. DRILL TWO RESERVOIR

INJECTION-WITHORAWAL WELLS. 


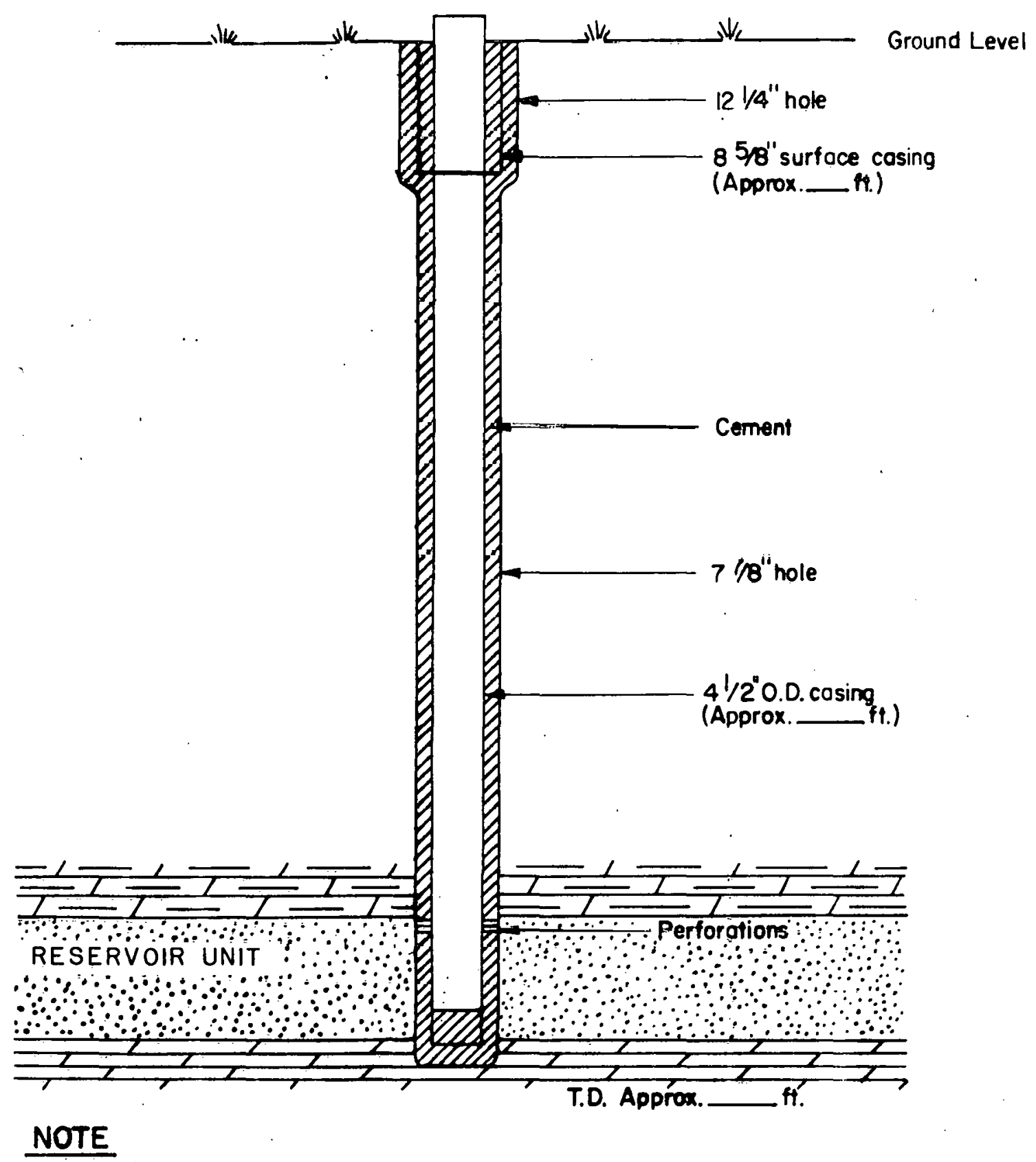

1. DRILL TWO RESERVOIR OBSERVATION WELLS. 


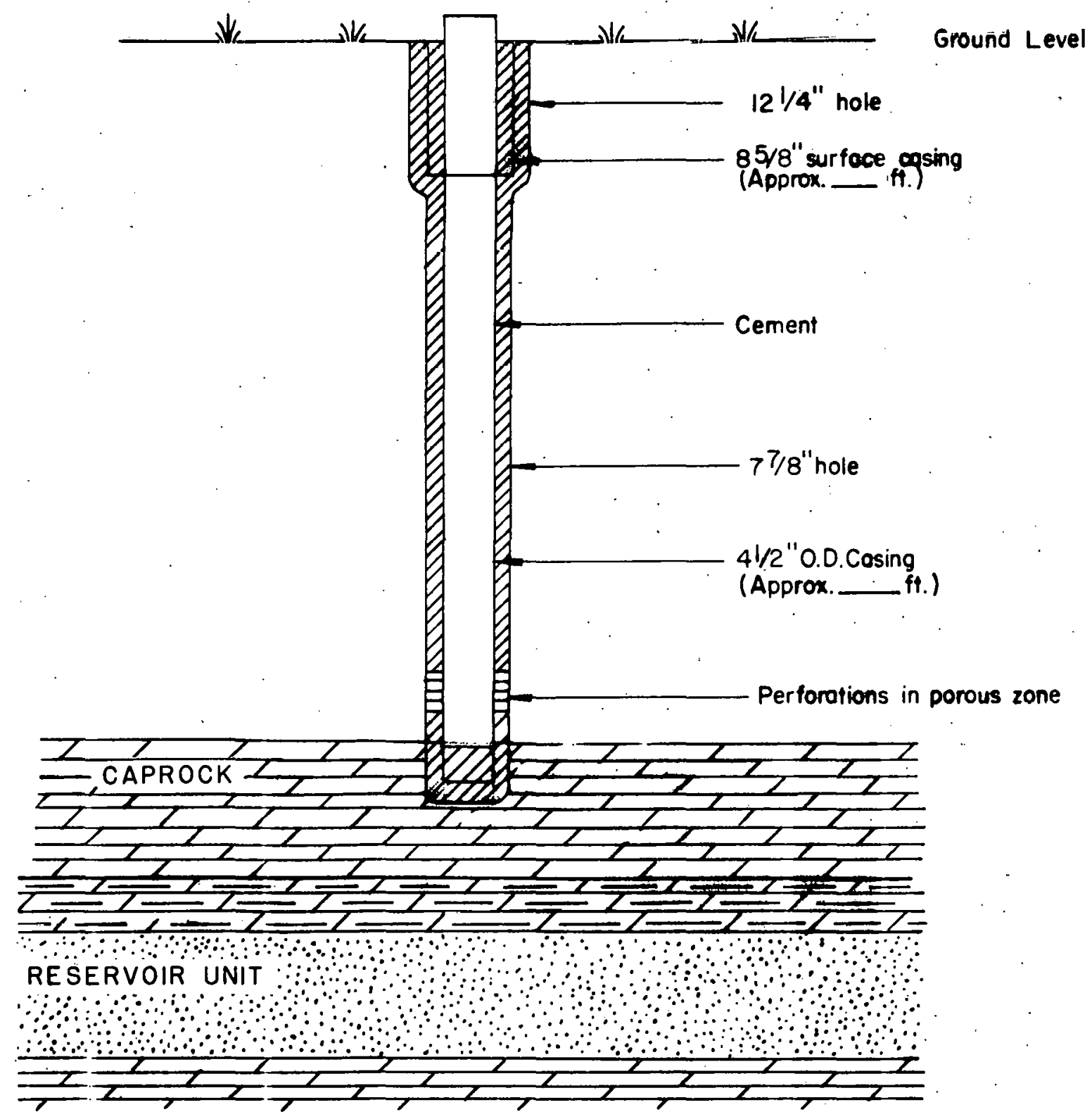

NOTE

I. Drill one coprock coservation well. 

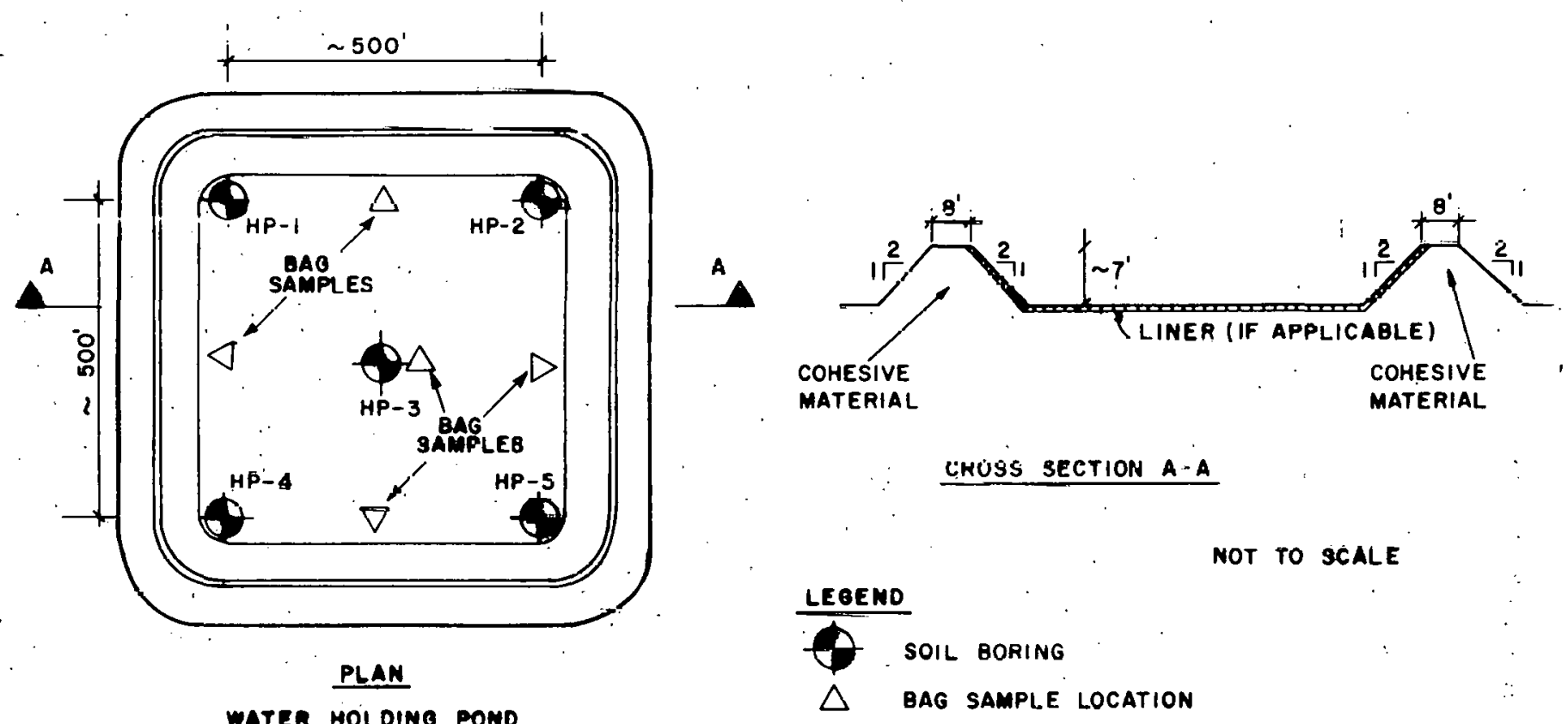

MATER HOLOINO POND

NOT TO SCALE

LEBEMO

AREA 5 ACRES

SCHEMATIC DRAWING OF. WATER HOLDING POND 